\title{
Results of Cultural Resources Survey for the Spring Lake Section 206 Aquatic Ecosystem Restoration Project, Texas State University-San Marcos, Hays County, Texas
}

Carole A. Leezer

Center for Archaeological Studies

David M. Yelacic

Jon C. Lohse

Center for Archaeological Studies

Frederick H. Hanselmann

Center for Archaeological Studies

Follow this and additional works at: https://scholarworks.sfasu.edu/ita

Part of the American Material Culture Commons, Archaeological Anthropology Commons, Environmental Studies Commons, Other American Studies Commons, Other Arts and Humanities Commons, Other History of Art, Architecture, and Archaeology Commons, and the United States History Commons

Tell us how this article helped you.

This Article is brought to you for free and open access by the Center for Regional Heritage Research at SFA ScholarWorks. It has been accepted for inclusion in Index of Texas Archaeology: Open Access Gray Literature from the Lone Star State by an authorized editor of SFA ScholarWorks. For more information, please contact cdsscholarworks@sfasu.edu. 
Results of Cultural Resources Survey for the Spring Lake Section 206 Aquatic Ecosystem Restoration Project, Texas State University-San Marcos, Hays County, Texas

Creative Commons License

(c) (1) \& 8

This work is licensed under a Creative Commons Attribution-NonCommercial 4.0 International License 
Results of Cultural Resources Survey

for the Spring Lake Section 206 Aquatic Ecosystem Restoration Project, Texas State University-San Marcos, Hays County, Texas
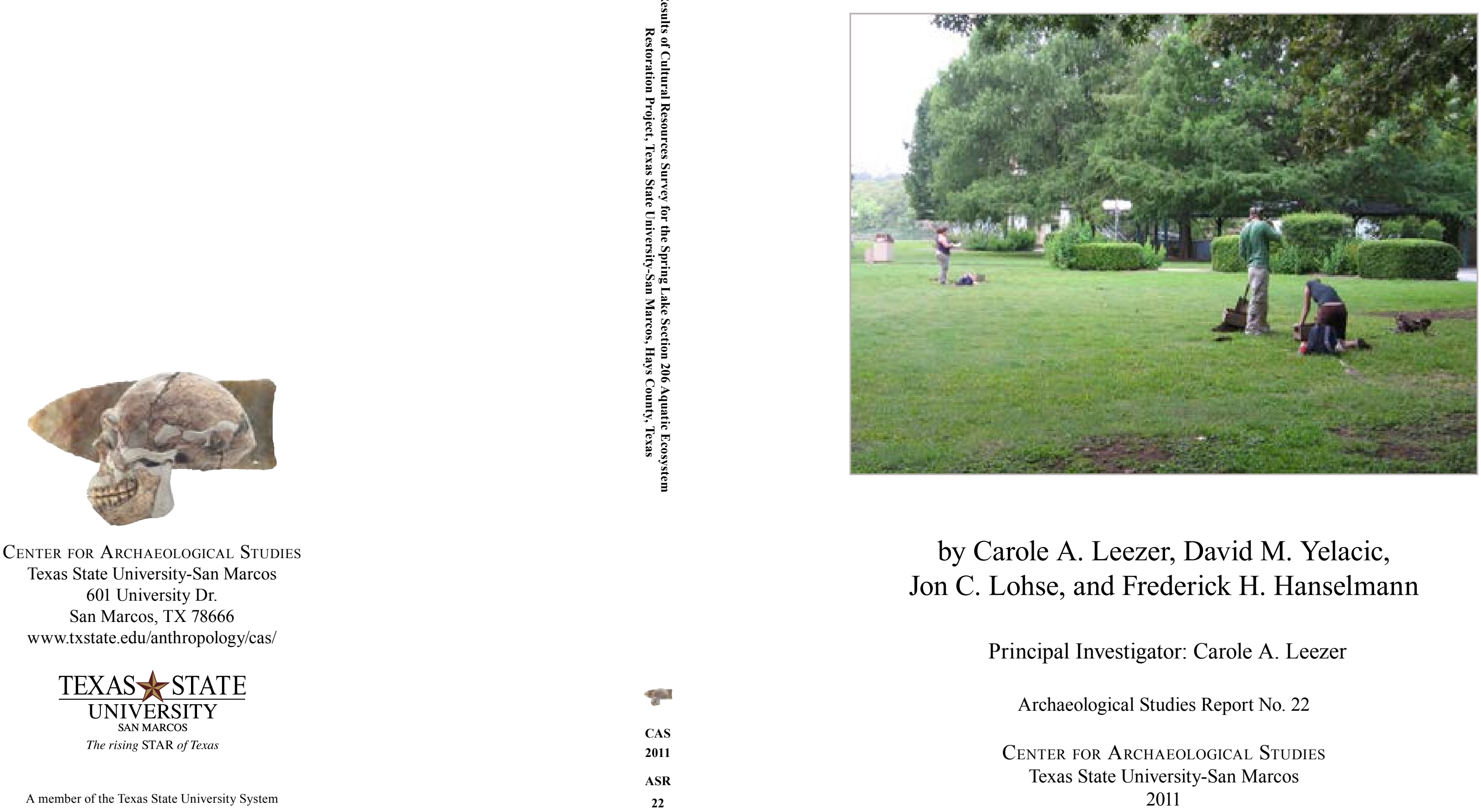

by Carole A. Leezer, David M. Yelacic, Jon C. Lohse, and Frederick H. Hanselmann

\section{Principal Investigator: Carole A. Leezer}

Archaeological Studies Report No. 22

Center for Archaeological Studies Texas State University-San Marcos 


\title{
Results of Cultural Resources Survey for the Spring Lake Section 206 Aquatic Ecosystem Restoration Project, Texas State University-San Marcos, Hays County, Texas
}

\author{
by \\ Carole A. Leezer, \\ David M. Yelacic, \\ Jon C. Lohse, \\ and
}

Frederick H. Hanselmann

Principal Investigator: Carole A. Leezer

Texas Antiquities Permit No. 5582

Archaeological Studies Report No. 22

CENTER FOR ARCHAEOLOGICAL STUDIES

Texas State University-San Marcos 
The following information is provided in accordance with the General Rules of Practice and Procedures, Title 13, Chapter 26, Texas Administrative Code:

1. Type of investigation: Intensive archaeological survey

2. Project name: Spring Lake Section 206 Aquatic Ecosystem Restoration Project Survey

3. County: Hays

4. Principal Investigator: Carole A. Leezer

5. Name and location of sponsoring agency: Texas State University-San Marcos

6. Published by the Center for Archaeological Studies, Texas State University-San Marcos, 601 University Drive, San Marcos, Texas, 78666-4616 (2011)

Texas State University-San Marcos is a member of the Texas State University System

Copyright (C) 2011 by the Center for Archaeological Studies at Texas State University-San Marcos

All rights reserved.

No part of this book may be reproduced or utilized in any form or by any means, electronic or mechanical, including photocopying, recording, or by any information storage and retrieval system without permission in writing.

For further information on this and other publications by the Center for Archaeological Studies, please contact:

Center for Archaeological Studies

Texas State University-San Marcos

601 University Drive

San Marcos, TX 78666-4616

www.txstate.edu/anthropology/cas/

Editor: Maggie McClain

Cover Photograph: Field technicians excavating shovel tests on the Aquarena Center peninsula.

Printed in the United States of America

by

Ginny's Printing Inc., Austin 


\section{Management Summary}

Project Title: Cultural Resource Assessment for the Spring Lake Section 206 Aquatic Ecosystem Restoration Project

Project Description: a subsurface testing program to determine the extent of intact cultural deposits within the project area

Local Sponsor: Texas State University-San Marcos

Federal Agency: United States Army Corps of Engineers

Institution: Center for Archaeological Studies, Texas State University-San Marcos

Principal Investigator: Carole Leezer

Project Archaeologist: Carole Leezer

Supervising Underwater Archaeologist: Fritz Hanselmann

Crew Members: David Yelacic, Josh Hamilton, Stephani Williams, Sarah Scogin, Jacob Hooge, Veronica Suarez, Brooke Boyer, Katherine Pratt, Julian A. Sitters, Renee Erickson, Holly Staggs, Amy Benton, and Courtney Coffey

Texas Antiquities Permit: 5582

Dates of Work: May 2010 through February 2011

Total Acreage Evaluated: 22 acres

Purpose of Work: To determine to the best level possible the horizontal and vertical distribution of cultural resources within the APE of the Spring Lake Section 206 Aquatic Ecosystem Restoration Project and to assess if the identified cultural resources will be negatively impacted by proposed demolition, modifications, and construction.

Number of Sites: 2-State Archeological Landmarks 41HY160 and 41HY165

Curation: Center for Archaeological Studies, Texas State University-San Marcos

Comments: Terrestrial and underwater archaeological investigations conducted. Six "Archaeologically Sensitive Areas" identified; four terrestrial and two underwater. CAS recommends the development of mitigative measures to offset the potential loss of information from these areas. 


\section{Abstract}

The Center for Archaeological Studies (CAS) at Texas State University-San Marcos conducted intensive archaeological survey and subsurface testing investigations of the Area of Potential Effect (APE) of the Spring Lake Section 206 Aquatic Ecosystem Restoration Project (SLAERP). The SLAERP proposes to restore the aquatic ecosystem components of Spring Lake and riparian corridor/grassland habitat located directly adjacent to the lake to a more natural condition within the constraints of existing land uses. This work will be conducted under Section 206 of the Water Resources Development Act of 1996, which provides authority for the United States Army Corps of Engineers (USACE) to restore aquatic ecosystems. A Memorandum of Agreement (MOA) between the USACE, Texas State University-San Marcos (TxState), and the Texas Historical Commission (THC) regarding the Spring Lake Aquatic Restoration Project required CAS to develop and implement a subsurface testing program to determine the extent of intact cultural deposits within the project area. A testing program was developed and implemented by CAS that included both terrestrial and underwater investigations. Terrestrial investigations consisted of pedestrian survey, shovel test excavation, test unit excavation, auger pit excavation and backhoe trench excavation. Underwater investigations included limited reconnaissance survey, test unit excavation and the extraction of sediment cores. Investigations were conducted within or adjacent to State Archaeological Landmarks 41HY160 and 41HY165. Neither site was adequately delineated prior to this undertaking, and the work reported here results in modified site boundaries within the APE. New site boundaries demonstrate nearly continuous deposits across the APE, confirming that these sites actually represent a single extensive complex of archaeological deposits associated with the freshwater springs that presently form Spring Lake. Based on pending impacts as indicated in the 65 percent project design documents together with the results of the survey, six areas were identified as "Archaeologically Sensitive," as they contained or possess a high probability to contain cultural deposits that would be negatively impacted by proposed demolition, modifications, and construction. Each of these archaeologically sensitive areas is linked with either $41 \mathrm{HY} 160$ or 41HY165, although, given the continuous nature of deposits in the APE, CAS concludes that distinctions between these trinomials are less meaningful than previously believed. CAS recommended the development of mitigation efforts to offset the loss of important information from these areas. 


\section{Table of Contents}

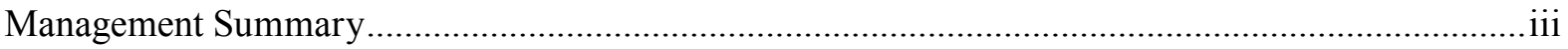

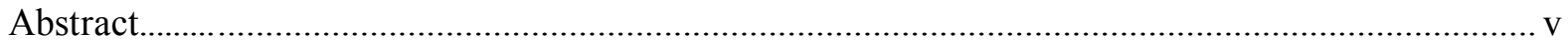

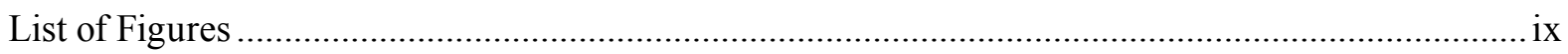

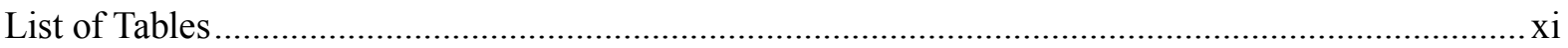

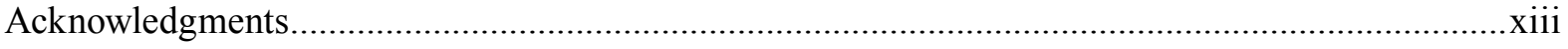

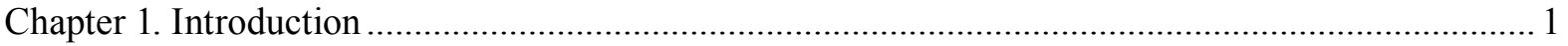

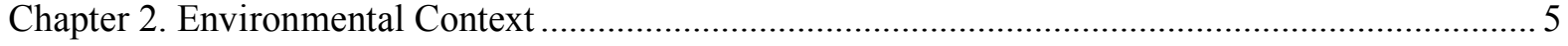

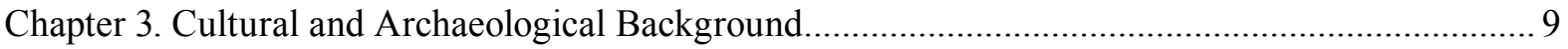

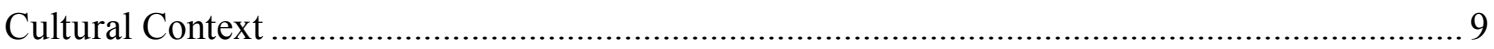

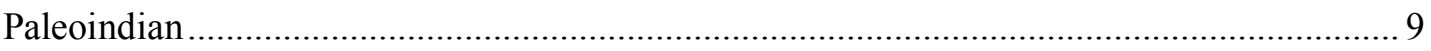

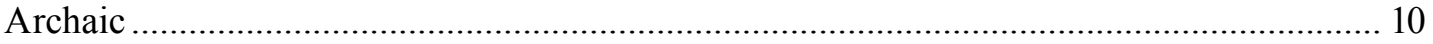

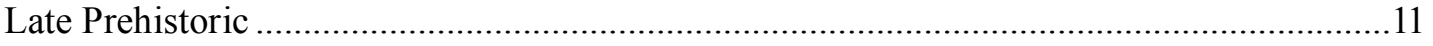

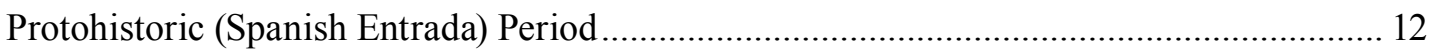

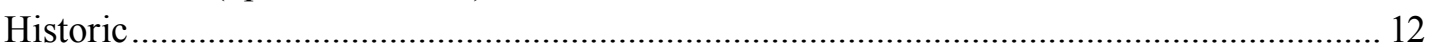

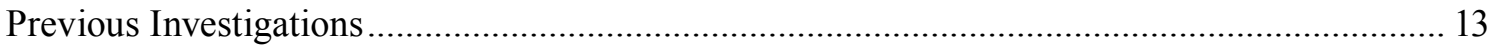

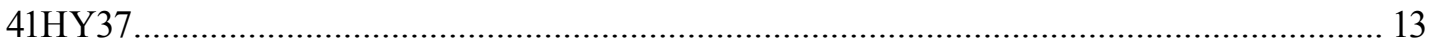

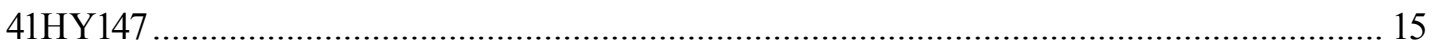

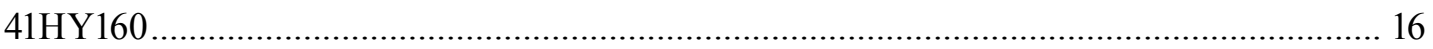

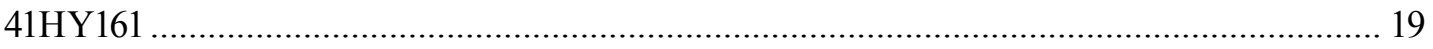

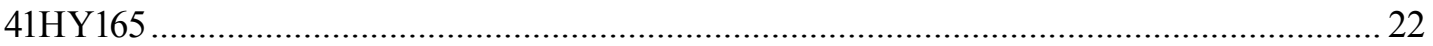

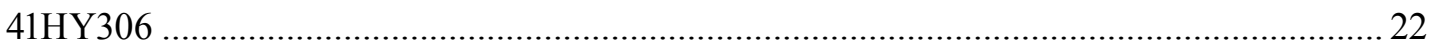

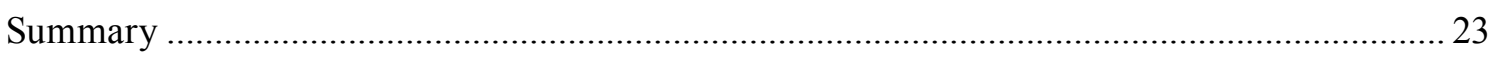

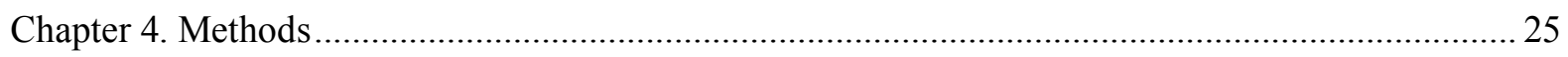

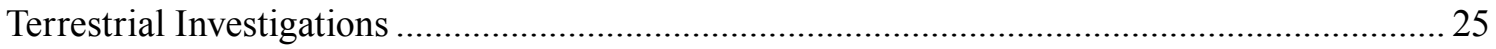

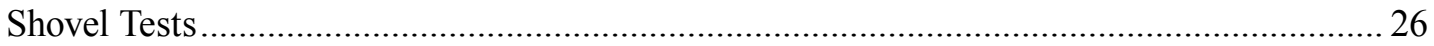

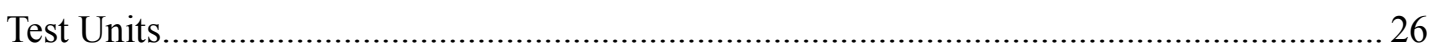

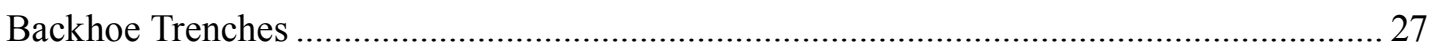

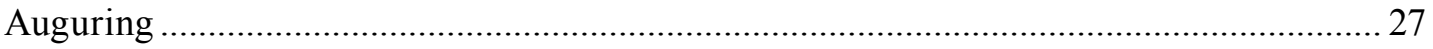

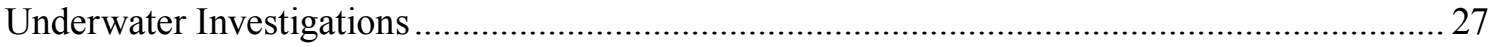

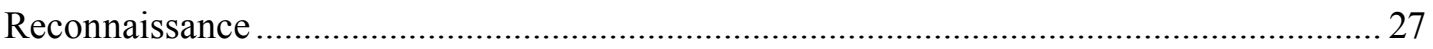

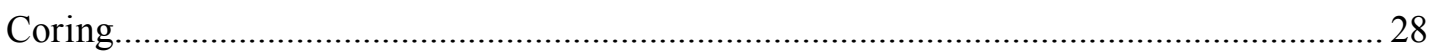

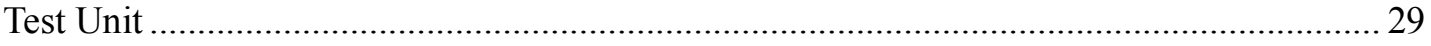

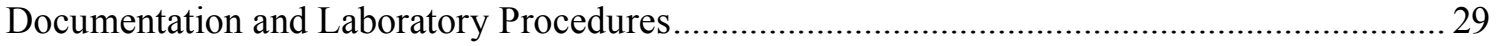

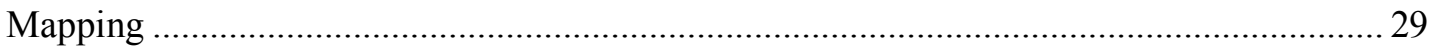

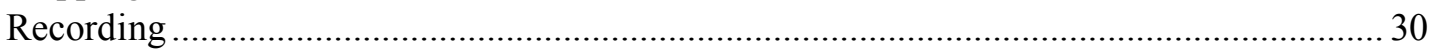

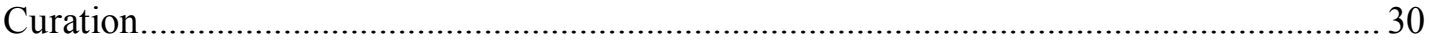

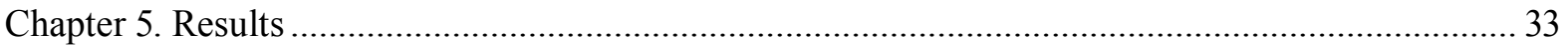

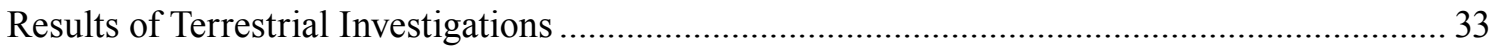

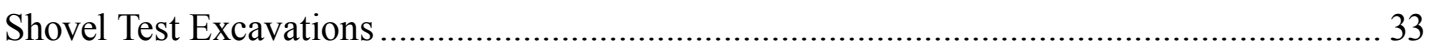




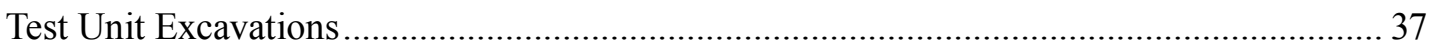

Backhoe Trench Excavations ......................................................................................... 39

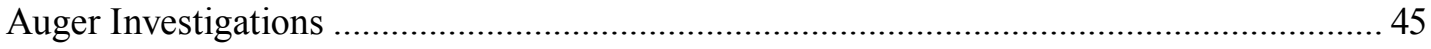

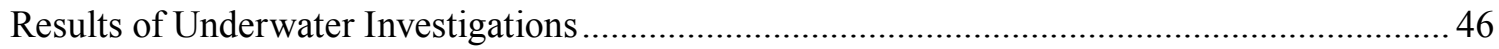

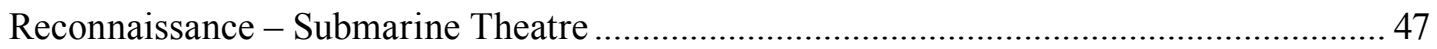

Reconnaissance - Upper Spring Lake .......................................................................... 47

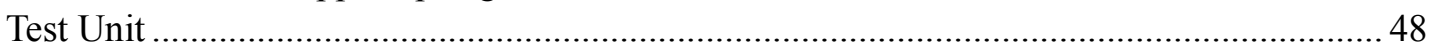

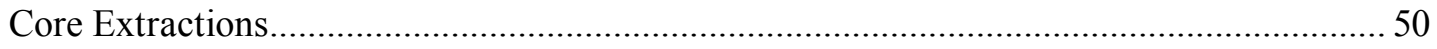

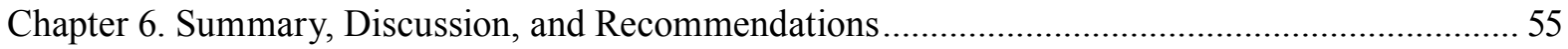

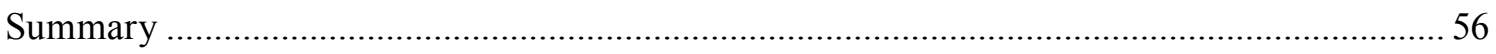

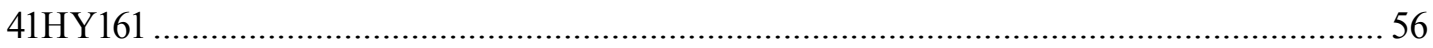

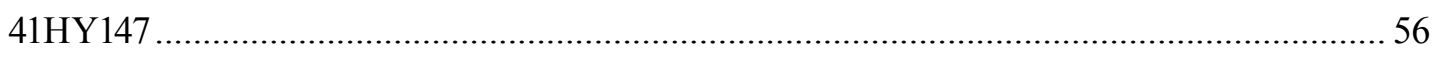

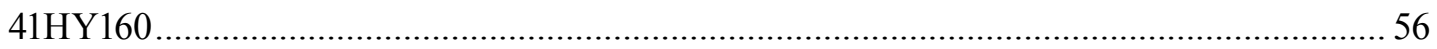

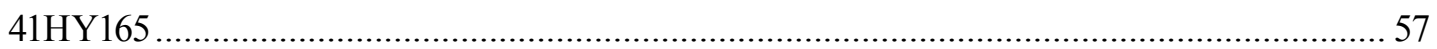

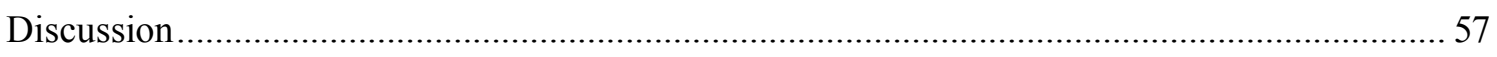

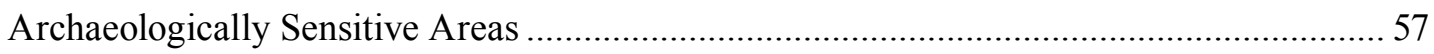

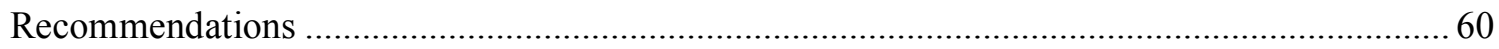

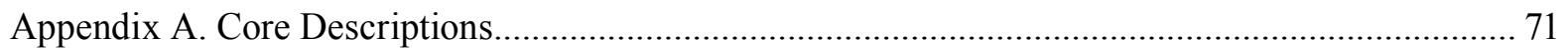

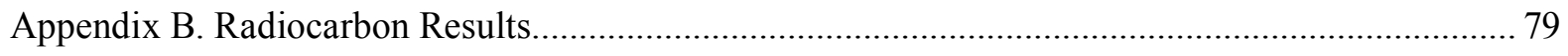

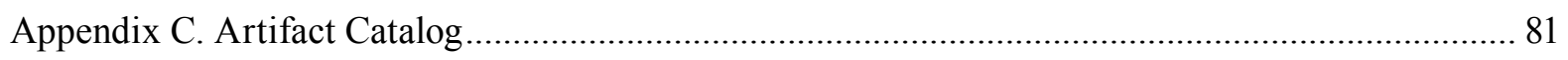

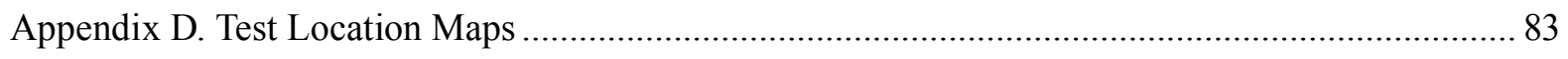

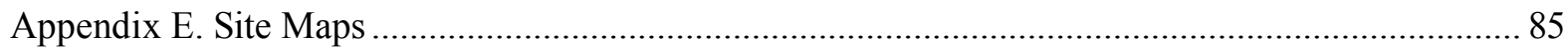




\section{List Of Figures}

Figure 1-1. Project area location on 7.5' United States Geological Survey topographic map, San Marcos North and South sheets; yellow polygon indicated by red arrow.

Figure 1-2. Spring Lake Section 206 Aquatic Ecosystem Restoration Project APE, outlined in yellow 3

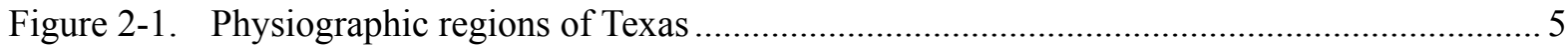

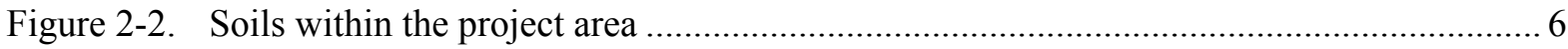

Figure 2-3. Reconstructed geoarchaeological cross section of Sink Creek Valley, looking upstream, illustrating alluvial units and their expected prehistoric preservation (redrawn from Nordt 2010:Figure 6-8).

Figure 4-1. CAS archaeologist using post-driver to insert PVC pipe into lake bed sediments..........28

Figure 4-2. Extracting 10 foot-long cores with barge and A-frame wench....................................... 29

Figure 4-3. Underwater archaeologists using air lift to excavate test unit ........................................ 30

Figure 5-1. Spring Lake Section 206 Aquatic Ecosystem Restoration Project sections .................... 33

Figure 5-2. Possible scraper/graver recovered from ST31 in Section 1........................................ 35

Figure 5-3. Possible Fairland point recovered from surface near eighth green................................ 36

Figure 5-4. Biface fragment recovered from ST135 in the far western portion of Section II............ 36

Figure 5-5. Probable Darl (left) and Ensor (right) point fragment recovered from Section III ......... 38

Figure 5-6. Profile of XU03 excavated within Section II............................................................... 39

Figure 5-7. Late Archaic points recovered from XU03, within Section II....................................... 40

Figure 5-8. Tip of point, drill, or needle recovered from Level 1 of XU03 ….................................. 40

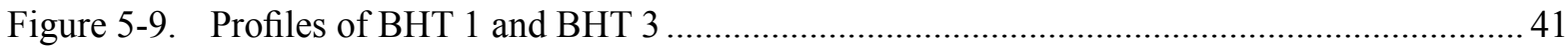

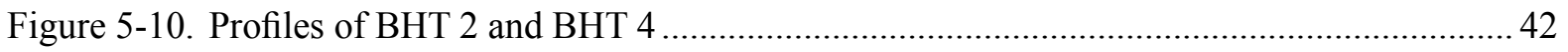

Figure 5-11. Late Archaic-period projectile point and biface recovered from BHT 3 ...................... 44

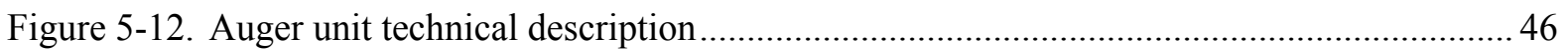

Figure 5-13. Rear of sub showing direct continuous contact between the lake bed and the base

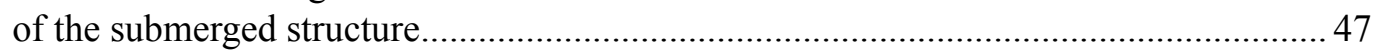

Figure 5-14. Part of the front of the sub where contact with lake bed sediments is intermittent......... 48

Figure 5-15. Underwater archaeologists conducting underwater reconnaissance survey ................... 48

Figure 5-16. Chipped stone biface on bottom of Spring Lake ........................................................... 49

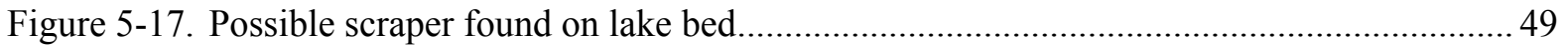

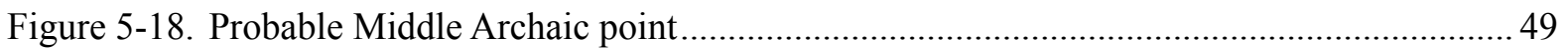

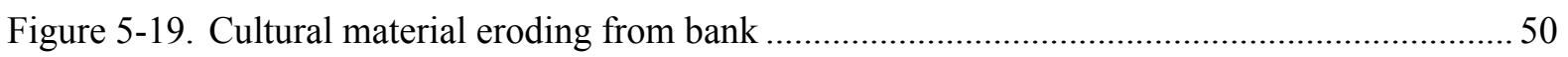

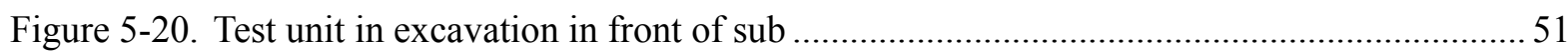

Figure 5-21. Archaeologist removing one of the sediment cores from near the sub.......................... 51 
Figure 5-22. Stratigraphic reconstruction based on results from coring, excavation, and radiocarbon analysis adjacent to the spring-side portion of sub .................................... 53

Figure 6-1. Projectile points documented at Deep Hole adjacent to proposed boat ramp location ... 58

Figure 6-3. Lithic debitage documented at Deep Hole adjacent to proposed boat ramp location ..... 59

Figure 6-2. Core documented at Deep Hole adjacent to proposed boat ramp location......................59 


\section{List OF TABLES}

Table 3-1. Previously Investigated Sites in the Spring Lake Vicinity .......................................... 14

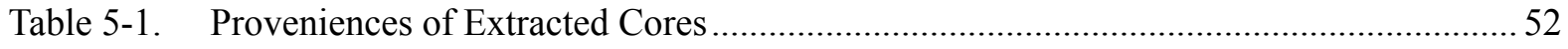

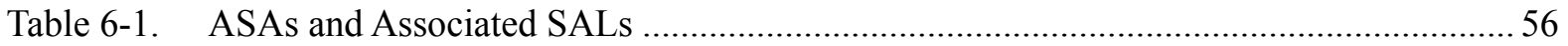




\section{ACKnOWledgments}

The Center for Archaeological Studies (CAS) at Texas State University-San Marcos sincerely appreciates the assistance provided by numerous individuals including Ron Coley and Deborah S. Lane of the Aquarena Center, Andy Samson and Mike Abbot of the Texas River Systems Institute, Juan Guerra and C. J. Hall of the Facilities Department at Texas State University, and Marty Underwood and Christi Shaw of the U.S. Army Corps of Engineers. Their assistance with the archaeological survey and concern for the cultural and historical legacy of project area are greatly valued.

Field and lab work was carried out by many individuals including David Yelacic, Josh Hamilton, Stephani Williams, Sarah Scogin, Jacob Hooge, Veronica Suarez, Brooke Boyer, Katherine Pratt, Julian A. Sitters, Renee Erickson, Holly Staggs, Amy Benton, Cinda Timperley, and Courtney Coffey. The underwater portion of the survey could not have been completed without Fritz Hanselmann, who acted as supervising Underwater Archaeologist. Additional assistance with the underwater portion of the survey was provided by Aaron M. Wallendorf and Taylor Herd of the Aquarena Center, as well as Jacob Hooge and Jon C. Lohse of CAS. Maggie McClain assisted with the technical editing and formatted this report. 


\section{Chapter 1}

\section{INTRODUCTION}

The Center for Archaeological Studies (CAS) at Texas State University-San Marcos conducted a cultural resource assessment for the Spring Lake Section 206 Aquatic Ecosystem Restoration Project (SLAERP). A Memorandum of Agreement (MOA) between the United States Army Corps of Engineers (USACE), Texas State University-San Marcos (TxState), and the Texas Historical Commission (THC) regarding the Spring Lake Aquatic Restoration Project, San Marcos, Texas, was signed and enacted in June 2009. The SLAERP proposes to restore the aquatic ecosystem components of Spring Lake and riparian corridor/grassland habitat located directly adjacent to the lake to a more natural condition within the constraints of existing land uses. This work will be conducted under Section 206 of the Water Resources Development Act of 1996, which provides authority for the USACE to restore aquatic ecosystems. USACE restoration projects are conducted in areas that affect water, such as rivers, lakes, and wetlands, and where the environment will benefit through restoration, improvement, or protection of aquatic habitats. The project costs are shared by the federal government (65 percent) and nonfederal local sponsor (35 percent), which in this case is TxState. In the current undertaking, it is the University's responsibility to ensure compliance with all cultural resource obligations under state and federal statute (the USACE will perform the role of lead federal agency for Section 106 coordination). The SLAERP proposed undertaking includes removal of existing structures and facilities at the Aquarena
Center, removal of all submerged structures, restoration of valuable aquatic and terrestrial habitats throughout the Spring Lake peninsula, removal of exotics, creation of a vegetated buffer zone between the golf course and Spring Lake, and construction of new and rehabilitated trails, traffic control gates, fencing, a rest room facility, picnic tables, benches, and signage.

The USACE, Fort Worth District, is the lead agency for this project. The nonfederal, local sponsor, TxState, is the participatory agency. The project area is located in south-central Texas, within the city limits of San Marcos on the TxState campus, and includes the Aquarena Center, Spring Lake, and part of the TxState golf course (Figure 1-1). The USACE, with the concurrence of the Texas State Historic Preservation Officer (SHPO) at the THC, has determined the Area of Potential Effect (APE) to be ten acres of floodplain habitat on the Aquarena Center peninsula, nine acres of riparian corridor habitat along the shoreline of Spring Lake, and 22 acres of lacustrine habitat within the headwaters of the San Marcos River (Figure 1-2).

The USACE has consulted with the THC and the Advisory Council on Historic Preservation (Council) pursuant to 36 CFR Part 800, regulations implementing Section 106 of the National Historic Preservation Act (NHPA) of 1966, as amended. An MOA for the SLAERP between the USACE, TxState, and the THC was developed as a result of this consultation. During the consultation, the USACE and the THC 


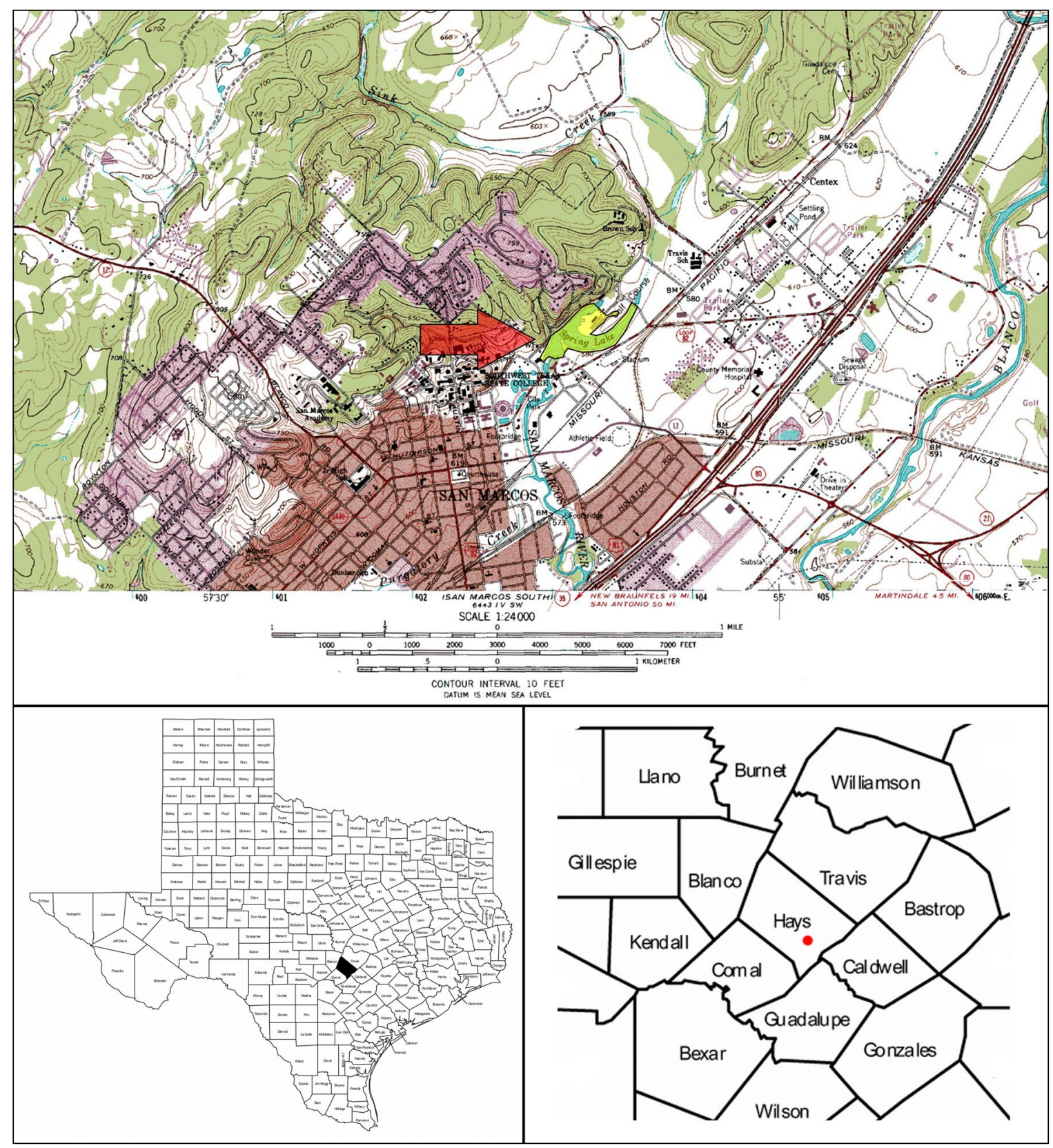

Figure 1-1. Project area location on 7.5' United States Geological Survey topographic map, San Marcos North and South sheets; yellow polygon indicated by red arrow.

determined that the Undertaking will have an adverse effect upon known properties included in or eligible for inclusion in the National Register of Historic Places (NRHP) and that have been designated as State Archeological Landmarks (SAL). It was also determined that potential also exists for negative impacts on yet-unknown resources that may be present.
The THC is authorized to enter into the MOA in order to fulfill its role of advising and assisting federal agencies in carrying out their Section 106 responsibilities pursuant to Sections 101 and 106 of the NHPA and 36 CFC Section 800.2 (1) (i) and 800.6 (b). The USACE, pursuant to 36 CFR Part 800.6(a)(1)(i) (c), has invited the Council to participate in this 


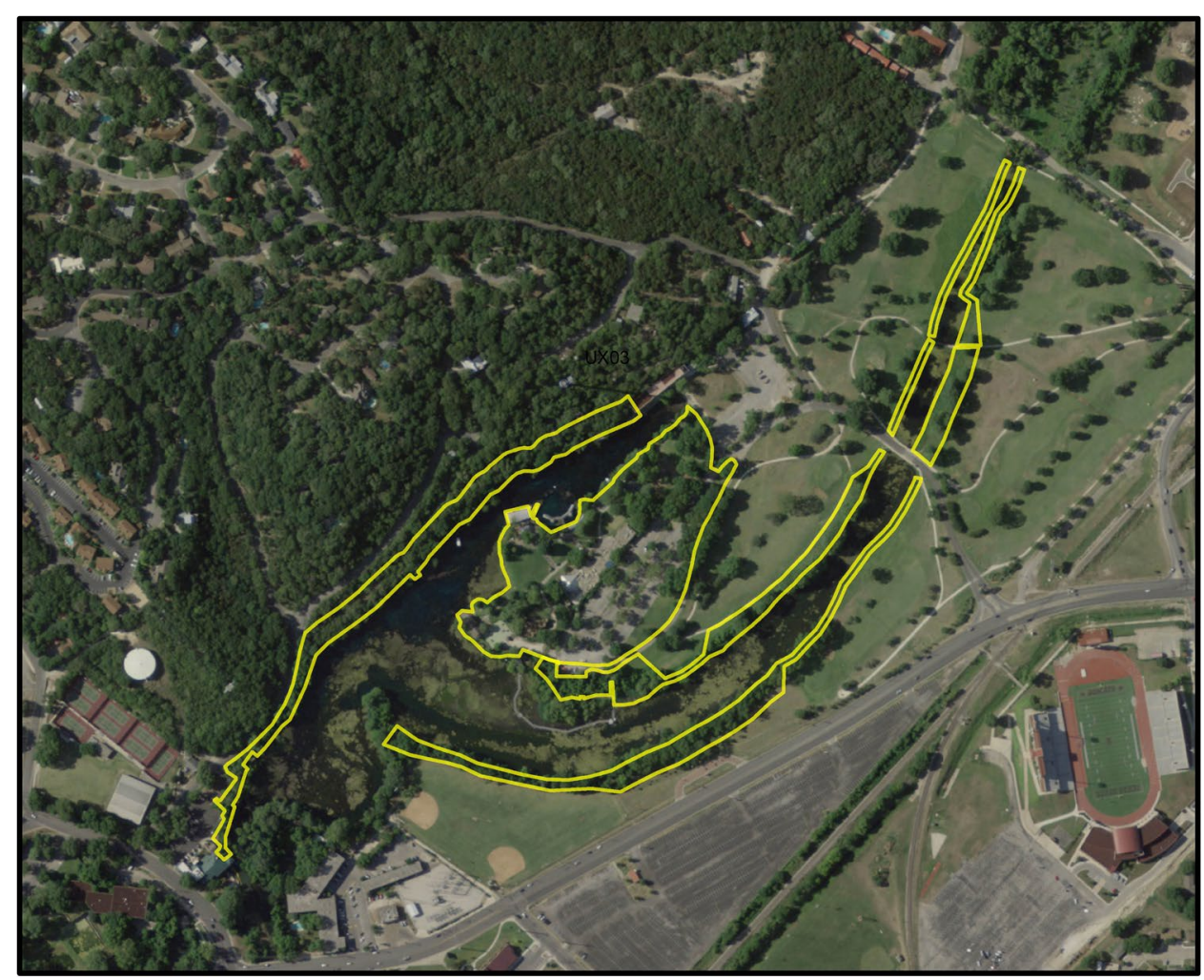

Figure 1-2. Spring Lake Section 206 Aquatic Ecosystem Restoration Project APE, outlined in yellow.

consultation, and the Council has chosen not participate. The Comanche Nation, the Kiowa Tribe of Oklahoma, the Mescalero Apache Tribe, and the Tonkawa Tribe of Oklahoma have also been invited to participate in consultation to seek ways to avoid, reduce, or mitigate adverse effects as the result of this undertaking and to concur in this agreement. These tribes have chosen not to be concurring parties to the MOA. TxState has determined that this MOA serves a public purpose by providing a means for it to meet its responsibilities under the NHPA.

The MOA requires the development and implementation of a Historic Properties Treatment Plan (HPTP) to ensure that the SLAERP will avoid or minimize impacts to cultural resources within the APE. The HPTP will include five subsections and will be subject to review and acceptance by the USACE Cultural Resources office. These five subsections include: 1) the development and implementation of a subsurface testing program to determine the extent of intact cultural deposits within the project area; 2) development of measures to coordinate closely with the project design team and convey cultural resource information to assure avoidance of historic properties during specific design phases of the project; 3) development and implementation of an excavation plan for each recorded site prior to construction; 4) development and implementation of an archaeological monitoring program to monitor all ground-disturbing activities during the construction and restoration phases of the project; and 5) a treatment plan to address adverse effects to cultural resources and unanticipated discoveries. The current document represents the results of work for a cultural resources survey and testing program of the APE (see Figure 1-2). 
In order to gather data necessary for completing the HPTP, the MOA calls for a cultural resource assessment of the APE. Four archaeological sites, 41HY160, 41HY165, 41HY161, 41HY147, have been recorded within the project area, and two additional sites, 41HY37 and $41 \mathrm{HY} 306$, are located within the vicinity. None of these sites were completely surveyed when they were recorded, and the boundaries of all sites are poorly and imprecisely known. Therefore, it is recognized that there is a high probability that ground-disturbing activities will encounter additional, yet-unknown cultural resources at or just below the surface that may appear to be outside the charted boundaries of any particular site.

Under Texas Antiquities Permit No. 5582 (Carole Leezer, Principal Investigator) CAS conducted an intensive cultural resource assessment and limited testing program of the APE consisting of pedestrian walkover survey augmented by systematic shovel test unit excavation, backhoe trench excavation, an auger excavation, and a limited number of test unit excavations. As the SLAERP includes the removal of all submerged structures and the restoration of aquatic habitats throughout the Spring Lake peninsula, a limited amount of underwater investigations of the locations of proposed modifications was also conducted. Data gathered during all of these assessments provides information on the vertical and horizontal extent of known and previously unknown archaeological sites, providing information to aid in the determination of potential impacts to cultural resources.

This report presents a summary of both terrestrial and underwater cultural resource assessments of the APE. As a result of this work, site boundaries for 41HY160 and 41HY165 are modified based on the documented presence of archaeological materials outside of previous site boundaries. Current boundaries indicate the nearly continuous presence of prehistoric remains across the APE. However, because pending impacts from the 65 percent design documents will be concentrated in only a few areas, we identify Archaeologically Sensitive Areas (ASA) within these two SALs. ASAs are areas that 1) represent intact and near-surface archaeological deposits that are associated with one of the SALs; 2) have the very high likelihood of containing significant deposits; and 3) will be adversely affected by the proposed undertaking.

The results of the survey and subsurface testing that are presented in this report will inform the HPTP. That document (forthcoming) will present recommendations for mitigating documented resources that will be affected by the proposed undertaking. The HPTP will be submitted for review as a separate report.

This chapter is followed by five chapters outlining the environmental context of the project area, a cultural and archaeological background, methods used in this survey, the survey results, and a summary of the findings and recommendations. These chapters are followed by five appendices. Appendix A describes the cores collected, and Appendix B contains the radiocarbon results. The remaining appendices are on $\mathrm{CD}$. Appendix $\mathrm{C}$ is the master artifact catalog, and Appendix D presents maps showing the locations of shovel tests, test units, cores, and the auger. Appendix E is for restricted access only, as it contains maps depicting site locations and archaeologically sensitive areas. 


\section{Chapter 2}

\section{Environmental Context}

The APE for the SLAERP includes Aquarena Center, Spring Lake, and a portion of the TxState golf course (see Figure 1-2), all located within the city limits of San Marcos on the TxState campus. The City of San Marcos is located in Hays County, in southeastern Central Texas. Spring Lake is fed by a series of artesian springs located at the base of the Balcones Escarpment, which marks the boundary between the Edwards Plateau (Hill Country) and the Blackland Prairie (Figure 2-1). This ecotonal zone (a transition area between two adjoining large-scale environmental provinces) is capable of supporting tremendous fauna and flora diversity (Crumley 1994) and could have supported dense human occupations in the past. Indeed, the San Marcos Springs have attracted human populations for over 13,500 years; they were known to early European settlers as St. Mark's, to the Tonkawas as Canocanayesatetlo, and today as Aquarena Springs (Brune 2005). The springs were an important stop on the El Camino Real and the Chisholm cattle trail. They are the second largest springs in Texas and support a tremendous amount of wildlife. The springs serve as the headwaters of the San Marcos River, which has provided power to gin, corn, saw, and grist mills and an ice factory in recent history.

Aquarena Center and the TxState golf course are situated at the base of the Balcones Escarpment on a deep, frequently flooded alluvial terrace at the confluence of the headwaters of the San Marcos River and adjacent intermittent tributary, Sink Creek. Clear artesian waters emanate from approximately 200 small springs and three large fissures along the Balcones Fault. Fluvial terrace deposits (Qal) composed of eroded gravel, sand, silt, and clay from the Edwards Plateau formed

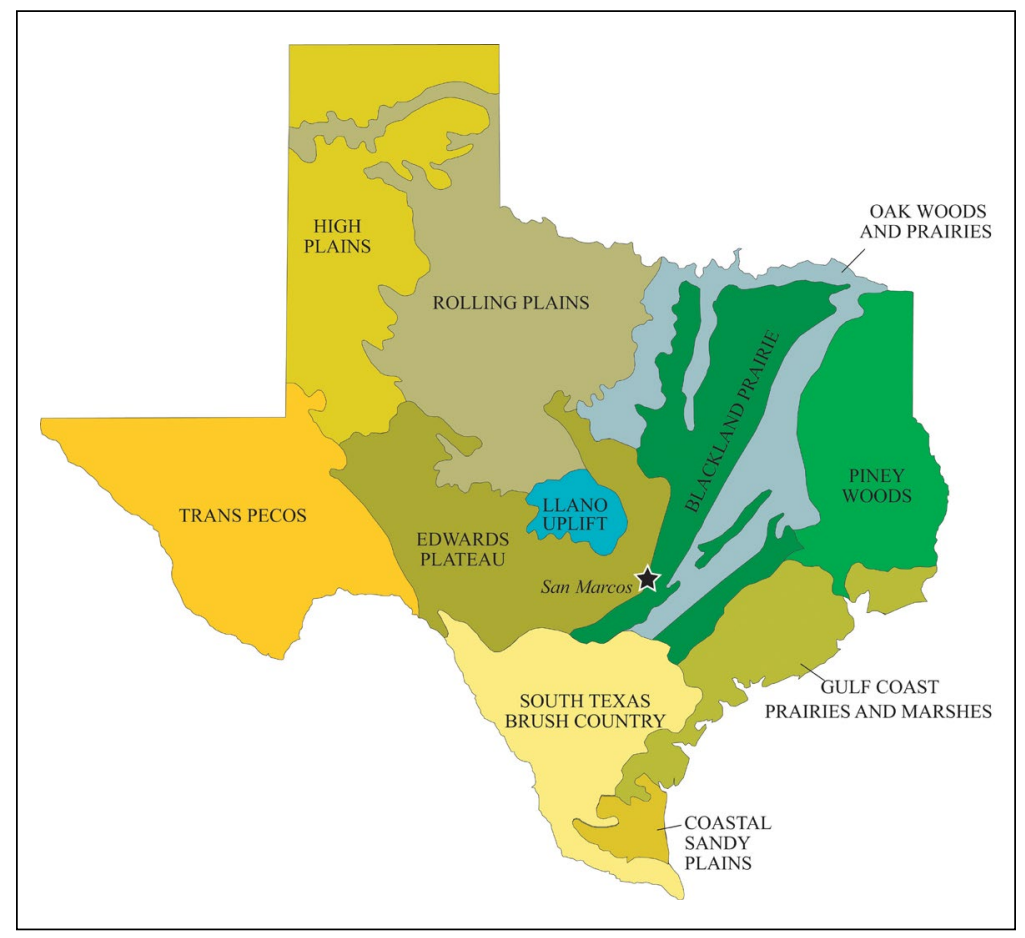

Figure 2-1. Physiographic regions of Texas. 


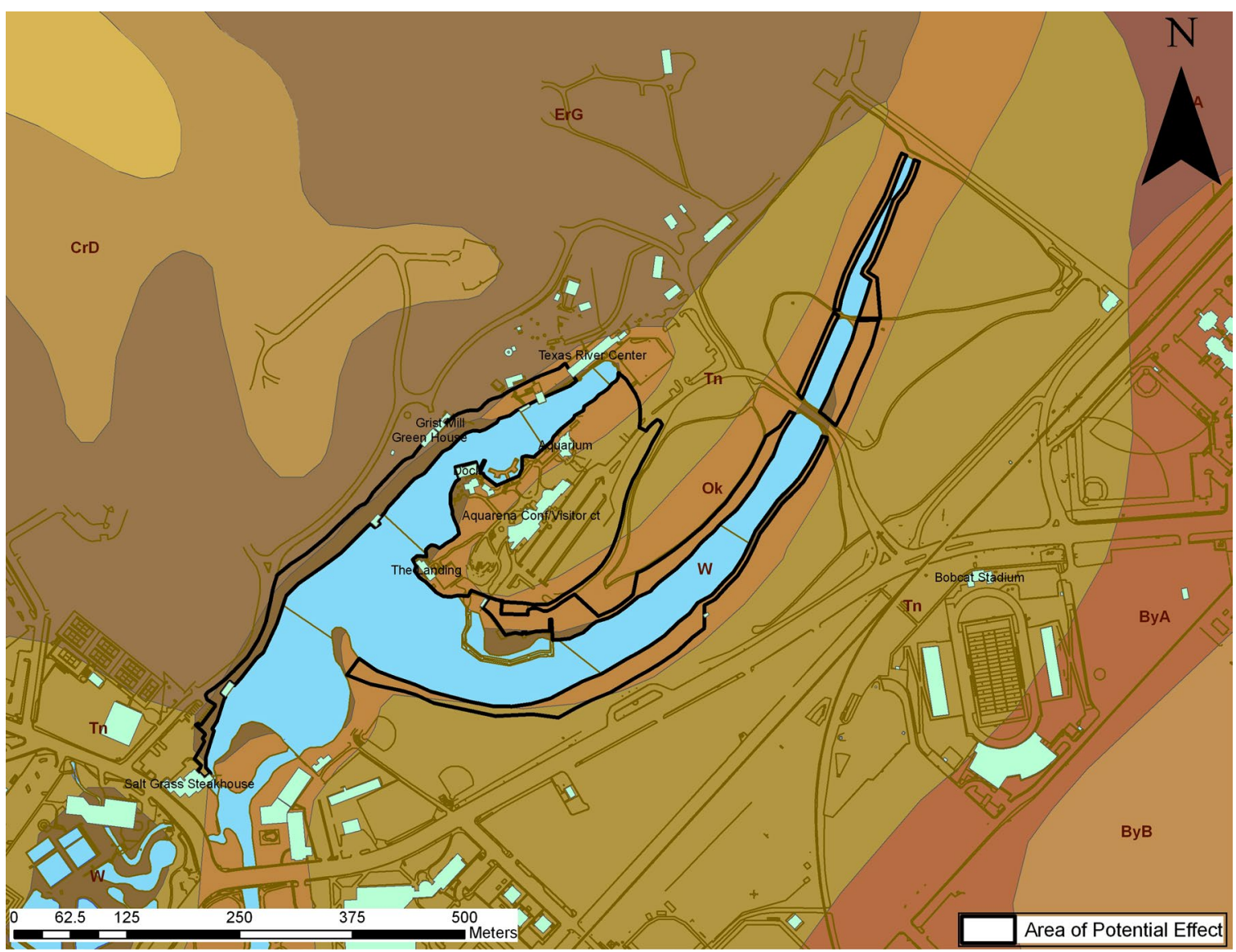

Figure 2-2. Soils within the project area.

along the upper San Marcos River from the Late Pleistocene to Late Holocene (Figure 2-2). Soils in the proposed project area consist of Oakalla clay loam (Ok) and Tinn clay (Tn) (Batte 1984).

Oakalla series soils are composed of an A-(B)-C soil column. A horizons typically reach approximately $80 \mathrm{~cm}$ in depth and consist of grayish-brown silty, clayey, loamy sediments. Oakalla series soils do not always contain a B horizon, which, if present, is generally grayishbrown to light yellowish-brown. Beneath either an $\mathrm{A}$ or $\mathrm{A}-\mathrm{B}$ horizons, the $\mathrm{C}$ horizon is also brown to light yellowish-brown. Similarly, Tinn series typically exhibit an A-(B)-C profile in which a deep (approximately 80 centimeters [cm]) A horizon ranges from dark gray at the top to dark grayish-brown with brown mottles at the bottom. Where present, $\mathrm{B}$ horizons are marked by brownish, yellowish, and olive mottles. Tinn series B horizons extend from approximately 80 to $135 \mathrm{~cm}$, though they can be thinner or not present at all. At the bottom of the Tinn series soil column, $\mathrm{C}$ horizons contain gray, brown, and olive mottles, and can possibly also contain up to 50 percent coarse fragments. The primary difference between these two soils series is distance from a stream; both soils form in floodplain settings, but Oakalla series are adjacent to streams and Tinn series are farther away. Slight differences in the Oakalla and Tinn series soil columns are attributable to variable moisture content/availability, which is partly a function of distance from the water exposed on the nearby surface.

Six Depositional Units (Units) of the Aquarena Center peninsula were identified by Lee 


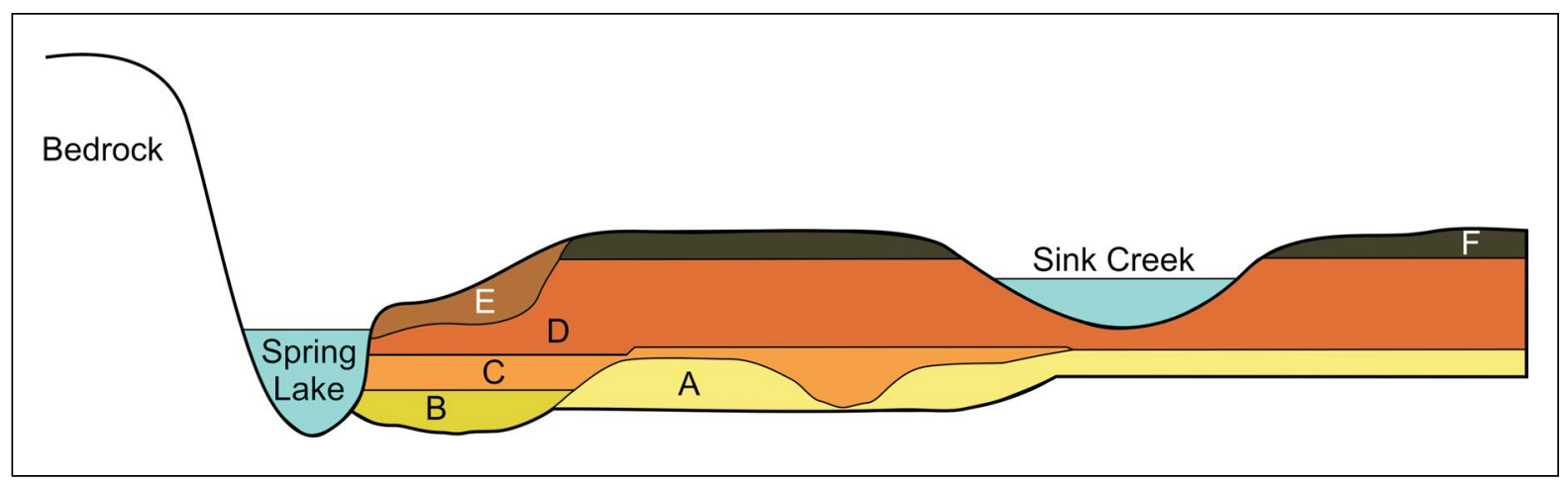

Figure 2-3. Reconstructed geoarchaeological cross section of Sink Creek Valley, looking upstream, illustrating alluvial units and their expected prehistoric preservation (redrawn from Nordt 2010:Figure 6-8).

C. Nordt (2010) during the 2001 investigations of 41HY160 (Figure 2-3). Units A through F reflect changes in the course of Sink Creek, including periods of increased and decreased stream flow, and changes in the resulting depositional regimes. These Units were deposited in chronological order, from oldest to most recent, and range from Paleoindian (A) to Late Prehistoric and Historic periods $(\mathrm{F})$.

Oakalla clay loam $(\mathrm{OK})$ soils are generally dark grayish-brown in color, moderately alkaline and calcareous throughout, with approximately 60 percent calcium carbonate, and contain an extremely firm to very hard, moderate, fine subangular blocky clay structure (Batte 1984:34, 75). This compact structure allows for less cracking and movement than other clays. This means that archaeological investigations within these soils should be less hampered by the movement of artifacts as a result of shrinking and swelling dynamics. Tinn clay (Tn) is generally dark gray to grayish-brown in color, and like Oakalla soils, is moderately alkaline and calcareous. Its structure, however, ranges from moderate, medium, and subangular to weak, medium, blocky. As a result of its clay and variable moisture contents, it is more likely to crack, thus allowing for possible vertical movement of artifacts. 


\section{Appendix B}

\section{Core Descriptions}

\section{David Yelacic}

The following tables supply technical descriptions for a total of ten sediment cores extracted around and near the submersible theatre along the southern bank of Spring Lake. Coring methods consisted of driving 2-1/2" PVC pipe into the lake bed with a very large post driver (slide hammer), capping and removing the sediment cores and transporting them to the Center for Archaeological Studies, draining excess water within each core, and exposing the sediment with longitudinal cuts on opposite sides of each PVC pipe. Once exposed, characteristics, including depth, color, texture, structure, consistency, and geologic, pedogenic, and biogenic features of the sediments were recorded. Measurements below are recorded in centimeters from the bottom to the top of each core, because of the core not being completely full and sediment consistently being present at the bottom-it is not clear whether the sediment was compacted by the physics of core-driving, or if the sediment at the bottom of each core acted as a plug displacing sediment below.

\section{Core 1, Site 2}

Location: Site 2 is on the north side of the westernmost portion of the sub.

\begin{tabular}{|c|c|c|}
\hline Zone & $\begin{array}{c}\text { Depth } \\
\text { (cm) }\end{array}$ & Description \\
\hline 1 & $41-48$ & $\begin{array}{c}\text { Black (7.5YR 2.5/1) silty loam; no apparent structure; very abrupt smooth lower } \\
\text { boundary; violently effervescent, common dark yellowish brown (10YR 4/6) mottles; } \\
<2 \% \text { coarse fragments; common fine shell fragments }\end{array}$ \\
\hline 2 & $29-41$ & $\begin{array}{l}\text { Very dark grayish brown (10YR } 3 / 2) \text { silty clay; no apparent structure; abrupt smooth } \\
\text { lower boundary; violently effervescent; < } 1 \% \text { coarse fragments; very wet after sitting out } \\
\text { for a day }\end{array}$ \\
\hline 3 & $19-29$ & $\begin{array}{l}\text { Black (7.5YR 2.5/1) silty loam; no apparent structure; abrupt smooth lower boundary; } \\
\text { violently effervescent; }<2 \% \text { coarse fragments; common fin shell fragments }\end{array}$ \\
\hline 4 & $13-19$ & $\begin{array}{c}\text { Very dark gray (7.5YR 3/1) silty loam; no apparent structure; very abrupt smooth lower } \\
\text { boundary; violently effervescent; }<1 \% \text { coarse fragments; at least one visible piece of } \\
\text { well-preserved organic matter }\end{array}$ \\
\hline 5 & $13-5$ & $\begin{array}{l}\text { Very dark brown (10YR } 2 / 2) \text { silty loam; no apparent structure; abrupt smooth lower } \\
\text { boundary; violently effervescent; }<5 \% \text { coarse fragments; common fine shell fragments }\end{array}$ \\
\hline 6 & $5-0$ & $\begin{array}{l}\text { Very dark gray (10YR 3/1) silty loam; violently effervescent; < } 1 \% \text { coarse fragments; } \\
\text { common fine shell fragments }\end{array}$ \\
\hline
\end{tabular}




\section{Core 2, Site 2}

Location: Site 2 is on the north side of the westernmost portion of the sub.

Remarks: This is the second core extracted from this location.

\begin{tabular}{|c|c|c|}
\hline Zone & $\begin{array}{c}\text { Depth } \\
\text { (cm) }\end{array}$ & Description \\
\hline 1 & $50-62$ & $\begin{array}{l}\text { Very dark grayish brown (10YR } 3 / 2) \text { silty loam; no apparent structure; very abrupt lower } \\
\text { boundary; violently effervescent; few rootlets; <1\% coarse fragments; few fine shell } \\
\text { fragments }\end{array}$ \\
\hline 2 & $49-50$ & $\begin{array}{l}\text { Light brownish gray }(2.5 \mathrm{Y} 6 / 2) \text { sandy loam; no apparent structure; very abrupt smooth } \\
\text { lower boundary; violently effervescent; }<1 \% \text { coarse fragments; very thin laminae on top } \\
\text { and bottom (Zone } 4 \text { ) of organic matter (Zone } 3 \text { ) }\end{array}$ \\
\hline 3 & $46-49$ & $\begin{array}{l}\text { Black (10YR 2/1) clay loam; no apparent structure; very abrupt smooth lower boundary; } \\
\text { violently effervescent; < } 1 \% \text { coarse fragments; organic rich! }\end{array}$ \\
\hline 4 & $44-46$ & $\begin{array}{l}\text { Light brownish gray }(2.5 \mathrm{Y} 6 / 2) \text { sandy loam; no apparent structure; very abrupt smooth to } \\
\text { wavy(?) lower boundary; violently effervescent; }<1 \% \text { coarse fragments; similar to Zone } 2\end{array}$ \\
\hline 5 & $35-44$ & $\begin{array}{l}\text { Very dark brown ( } 10 \text { YR } 2 / 2 \text { ) silt loam; no apparent structure; abrupt smooth lower } \\
\text { boundary; violently effervescent; <5\% coarse fragments; small gravels near upper } \\
\text { boundary; common fine shell fragments }\end{array}$ \\
\hline 6 & $26-35$ & $\begin{array}{l}\text { Very dark grayish brown (10YR 3/2) clay loam; no apparent structure; abrupt smooth } \\
\text { lower boundary; violently effervescent; Same as Zone 2, Core 1, Site 2; sampled: SLC-2- } \\
\qquad 2-1(28-35 \mathrm{~cm}, 144.79 \mathrm{~g})\end{array}$ \\
\hline 7 & $18-26$ & $\begin{array}{l}\text { Very dark gray }(10 \mathrm{YR} 3 / 1) \text { clay loam; no apparent structure; abrupt smooth lower } \\
\text { boundary; violently effervescent; }<1 \% \text { coarse fragments; some possible organic material; } \\
\text { wetter than other sediments, taking into account that all have been exposed for }>24 \text { hours }\end{array}$ \\
\hline 8 & $4-18$ & $\begin{array}{l}\text { Very dark grayish brown (10YR 3/2) clayey loam; no apparent structure; very abrupt } \\
\text { smooth lower boundary; violently effervescent; few rootlets; common fine shell } \\
\text { fragments; sampled: SLC-2-2-6 (5-12 cm, } 83.88 \mathrm{~g})\end{array}$ \\
\hline 9 & $0-4$ & $\begin{array}{c}\text { Very dark grayish brown (10YR 3/2) silty loam; weak to moderate fine subangular blocky } \\
\text { structure; violently effervescent; clay coats on clasts; > } 20 \% \text { coarse fragments; common } \\
\text { strong brown ( } 7.5 \text { YR } 5 / 8) \text { mottling or transition to reddish gravelly stratum-not enough } \\
\text { sediment to be sure }\end{array}$ \\
\hline
\end{tabular}




\section{Core 3, Site 3}

Location: Site 3 is located on the north side of the eastern portion of the sub.

\begin{tabular}{|c|c|c|}
\hline Zone & $\begin{array}{l}\text { Depth } \\
\text { (cm) }\end{array}$ & Description \\
\hline 1 & $27-40$ & $\begin{array}{c}\text { Very dark gray (10YR 3/1) clay loam; no apparent structure; abrupt smooth lower } \\
\text { boundary; violently effervescent; clay coats on clasts; } 15 \% \text { coarse fragments; common } \\
\text { dark yellowish brown (10YR 4/4) mottles }\end{array}$ \\
\hline 2 & $18-27$ & $\begin{array}{l}\text { Very dark gray (10YR 3/1) silty loam; no apparent structure; abrupt smooth lower } \\
\text { boundary; violently effervescent; clay and carbonate(?) cotas on clasts; } 20 \% \text { coarse } \\
\text { fragments; common yellowish brown (10YR 5/6) mottles; sample: SLC-3-3-7 }(18-25 \mathrm{~cm} \text {, } \\
158.30 \mathrm{~g})\end{array}$ \\
\hline 3 & $10-18$ & $\begin{array}{l}\text { Very dark gray (10YR 3/1) clay loam; no apparent structure; very abrupt smooth lower } \\
\text { boundary; violently effervescent; clay and carbonate(?) coats on clasts; }>50 \% \text { coarse } \\
\text { fragment, matrix supported; common dark yellowish brown (10YR 4/4) mottles }\end{array}$ \\
\hline 4 & $3-10$ & $\begin{array}{l}\text { Very dark grayish brown }(10 \mathrm{YR} 3 / 2) \text { sandy loam; no apparent structure; very abrupt } \\
\text { smooth lower boundary; violently effervescent; < } 1 \% \text { coarse fragments; few yellowish } \\
\text { brown }(10 \mathrm{YR} 5 / 6) \text { mottles; sample: SLC-3-3-2 }(0-8 \mathrm{~cm}, 106.26 \mathrm{~g})\end{array}$ \\
\hline 5 & $0-3$ & $\begin{array}{l}\text { Light olive brown (10YR 5/3) silty loam; no apparent structure; violently effervescent; } \\
\text { clay and carbonate(?) coats on clasts; } 50 \% \text { coarse fragments, matrix supported }\end{array}$ \\
\hline
\end{tabular}

\section{Core 7, Site 6}

Location: Site 6 is located off the north end of the westernmost portion of the sub; contrasting to the other core locations, this one had thick vegetation.

Remarks: This particular sample was especially difficult to remove.

\begin{tabular}{|c|c|c|}
\hline Zone & $\begin{array}{l}\text { Depth } \\
\text { (cm) }\end{array}$ & Description \\
\hline 1 & $58-69$ & $\begin{array}{l}\text { Dark grayish brown (10YR 4/2) silty loam; no apparent structure; very abrupt lower } \\
\text { boundary; violently effervescent; } 10 \% \text { coarse fragments common strong brown (7.5YR } \\
5 / 6) \text { mottles }\end{array}$ \\
\hline 2 & $53-58$ & $\begin{array}{l}\text { Very dark brown (10YR } 2 / 2) \text { loam; no apparent structure; very abrupt lower boundary; } \\
80 \% \text { coarse fragments, clast supported; interpreted as historic/modern pea-gravel fill }\end{array}$ \\
\hline 3 & $31-53$ & $\begin{array}{l}\text { Dark yellowish brown (10YR 4/6) clay loam; strong medium subangular blocky; firm; } \\
\text { very abrupt lower boundary; violently effervescent; clay coats on clasts; fine carbonate } \\
\text { nodules; } 30 \% \text { coarse fragments; sample: SLC-7-6-3 (40-48 cm, } 192.78 \mathrm{~g})\end{array}$ \\
\hline 4 & $0-31$ & $\begin{array}{c}\text { Dark yellowish brown (10YR 4/6) clay loam; strong medium subangular blocky; } \\
\text { extremely firm; violently effervescent; fine carbonate nodules; < } 15 \% \text { coarse fragments; } \\
\text { this zone was only damp when opened-very compact and exhibiting well-developed ped } \\
\text { structure; sample: SLC-7-6 }(20-27 \mathrm{~cm}, 198.96 \mathrm{~g})\end{array}$ \\
\hline
\end{tabular}




\section{**Note that the following six core descriptions are the result of a second phase of coring, which included investigating the bank-side of the sub as well as the end of the peninsula.**}

\section{Core 8, Site 7}

Location: Site 7 is located behind the west end of the sub.

Remarks: Sediment is contained in the bottom foot of a 4-ft coring tube (tube was inserted much more).

\begin{tabular}{ccc}
\hline Zone & $\begin{array}{c}\text { Depth } \\
(\mathbf{c m})\end{array}$ & Description \\
\hline Strong brown $(7.5 Y$ Y 4/6) clay; moderate medium blocky structure; friable; violently \\
1 & $0-32$ & $\begin{array}{c}\text { Sffervescent; fine nodular and filamental carbonate increased in lower } 12 \mathrm{~cm} ;<1 \% \\
\text { coarse fragments; common clay coats on ped faces and in pore spaces; }<1 \% \text { possible Mn } \\
\text { nodules; 30\% oxidation features }\end{array}$ \\
\hline
\end{tabular}

\section{Core 9, Site 8}

Location: Site 8 was located just west of access bridge on south side of the sub.

\begin{tabular}{|c|c|c|}
\hline Zone & $\begin{array}{l}\text { Depth } \\
\text { (cm) }\end{array}$ & Description \\
\hline 1 & $35-48$ & $\begin{array}{l}\text { Dark yellowish brown (10YR 4/4) clay; weak medium blocky structure; friable; abrupt } \\
\text { lower boundary; violently effervescent; common faint clay coats on ped faces; } 3 \% \text { coarse } \\
\text { fragments; round pebbles at very top of core-interpreted as historic/modern pea-gravel } \\
\text { fill }\end{array}$ \\
\hline 2 & $21-35$ & $\begin{array}{l}\text { Dark brown }(7.5 \mathrm{YR} 3 / 4) \text { clay; moderate medium blocky structure; friable; clear lower } \\
\text { boundary; violently effervescent; filament carbonate; common fain clay coats on ped } \\
\text { faces; }<2 \% \text { coarse fragments; }\end{array}$ \\
\hline 3 & $11-21$ & $\begin{array}{l}\text { Yellowish brown (10YR 5/6) clay; moderate medium blocky structure; friable; clear lower } \\
\text { boundary; filament and fine nodular carbonates; common faint clay coats on ped faces; } \\
\qquad 10 \% \text { coarse fragments (carbonate nodules) }\end{array}$ \\
\hline 4 & $0-11$ & $\begin{array}{l}\text { Yellowish brown (10YR } 5 / 6) \text { clay; moderate medium blocky structure; friable; common } \\
\text { clay coats on ped faces; } 10 \% \mathrm{Mn} \text { concretions; }<1 \% \text { coarse fragments }\end{array}$ \\
\hline
\end{tabular}

Remarks: Sediment contained in the bottom third of 4-ft coring tube (tube was inserted much more). 


\section{Core 10, Site 9}

Location: Site 9 is located on the southeast side of the sub, to the east of the access bridge. Remarks: Sediment is contained in the lower approximately $2 \mathrm{ft}$ of a 6 -ft core tube.

\begin{tabular}{|c|c|c|}
\hline Zone & $\begin{array}{c}\text { Depth } \\
\text { (cm) }\end{array}$ & Description \\
\hline 1 & $63-73$ & $\begin{array}{l}\text { Approximately } 80 \% \text { black clay (10YR 2/1) clay loam and } 20 \% \text { dark yellowish brown } \\
\text { (10YR 4/4) clay, a mixture of Zones } 3 \text { and } 4 \text {, respectively; structureless; friable; abrupt } \\
\text { lower boundary; } 40 \% \text { coarse fragments, including historic/modern pea-gravel fill }\end{array}$ \\
\hline 2 & $38-63$ & $\begin{array}{c}\text { Approximately } 55 \% \text { black clay (10YR } 2 / 1) \text { clay loam and } 45 \% \text { dark yellowish brown } \\
\text { (10YR 4/4) clay, a mixture of Zones } 3 \text { and } 4 \text {, respectively; structureless; friable; abrupt } \\
\text { lower boundary; }<5 \% \text { coarse fragments }\end{array}$ \\
\hline 3 & $28-38$ & $\begin{array}{c}\text { Black (10YR 2/1) clay loam; structureless to very weak fine blocky structure; very friable } \\
\text { very abrupt lower boundary; } 10 \% \text { coarse fragments; common shell fragments, }<2 \mathrm{~mm}, 1 \\
\text { bivalve, } 1 \text { fine ramshorn; contains at least one charcoal fleck }\end{array}$ \\
\hline 4 & $12-28$ & $\begin{array}{c}\text { Dark yellowish brown }(10 \mathrm{YR} 4 / 4) \text { clay; weak medium blocky structure; friable; abrupt } \\
\text { lower boundary; uncommon discontinuous faint fine redox features (masses/depletions); } \\
<1 \% \text { coarse fragments; sample: SLC-9-3 }(22-26 \mathrm{~cm}, 52.82 \mathrm{~g})\end{array}$ \\
\hline 5 & $0-12$ & $\begin{array}{c}\text { Dark yellowish brown (10YR 4/4) clay; moderate medium blocky structure; friable; } 10 \% \\
\text { carbonate fine nodules and filaments; }<10 \% \text { redox features (masses } / \text { coats); }<10 \% \text { clay } \\
\text { faint clay coats; }<3 \% \text { coarse fragments }\end{array}$ \\
\hline
\end{tabular}

\section{Core 11, Site 10}

Location: Site 10 is the easternmost sample, and is located between the glass-bottom boat dock and the east end of the sub.

Remarks: Sediment is contained in the lower $2.5 \mathrm{ft}$ of a 6 - $\mathrm{ft}$ core tube.

\begin{tabular}{|c|c|c|}
\hline Zone & $\begin{array}{c}\text { Depth } \\
\text { (cm) }\end{array}$ & Description \\
\hline 1 & $50-75$ & $\begin{array}{l}\text { Black (5Y 2.5/2) clay loam; structureless; friable; abrupt lower boundary; effervescent; } \\
\text { abundant roots; } 5 \% \text { coarse fragments; modern accumulation }\end{array}$ \\
\hline 2 & $34-50$ & $\begin{array}{c}\text { Very dark grayish brown }(2.5 \mathrm{Y} 3 / 2) \text { clay loam; structureless; very friable; abrupt lower } \\
\text { boundary; effervescent; } 20 \% \text { coarse fragments, common roots; including historic/modern } \\
\text { pea-gravel fill; great amount of well-preserved organic matter }\end{array}$ \\
\hline 3 & $27-34$ & $\begin{array}{l}\text { Very dark grayish brown ( } 2.5 \mathrm{Y} 3 / 2) \text { clay loam; structureless; very friable; abrupt smooth } \\
\text { lower boundary; effervescent; similar to Zone 2, but without gravel }\end{array}$ \\
\hline 4 & $17-27$ & $\begin{array}{l}\text { Black (10YR 2/1) clay loam; weak medium blocky structure; very friable; effervescent; } \\
\text { very abrupt and irregular lower boundary; } 3 \% \text { coarse fragments; sample: SLC-10-4 } \\
\qquad(20-24 \mathrm{~cm}, 41.69 \mathrm{~g})\end{array}$ \\
\hline 5 & $12-17$ & Approximately $65 \%$ Zone 6 and $35 \%$ Zone 4 \\
\hline 6 & $0-12$ & $\begin{array}{l}\text { Strong brown ( } 7.5 \text { YR } 4 / 6 \text { ) clay; weak medium blocky structure; firm; common fine } \\
\text { carbonate nodules; uncommon faint redox features; }<2 \% \text { coarse fragments }\end{array}$ \\
\hline
\end{tabular}




\section{Core 12, Site 11}

Location: Site 11 is approximately $10 \mathrm{~m}$ off the west end of the peninsula.

Remarks: Sediments contained in the bottom approximately $4 \mathrm{ft}$ of a 10 -ft core.

\begin{tabular}{|c|c|c|}
\hline Zone & $\begin{array}{l}\text { Depth } \\
\text { (cm) }\end{array}$ & Description \\
\hline 1 & $96-136$ & $\begin{array}{l}\text { Black (5Y 2.5/2) loam; structureless; loose; clear lower boundary; spongey texture; } \\
\text { abundant roots; } 1 \% \text { coarse fragments }\end{array}$ \\
\hline 2 & $75-96$ & $\begin{array}{l}\text { Very dark gray }(2.5 \mathrm{Y} 3 / 1) \text { loam; stuctureless; loose (very wet); clear lower boundary; } \\
\text { common roots; }<1 \% \text { coarse fragments; } 2-5 \% \text { snails, hydrobiidae and very small physidae } \\
\text { (both freshwater); spongey }\end{array}$ \\
\hline 3 & $52-75$ & Same as Zone 2; clear lower boundary \\
\hline 4 & $23-52$ & $\begin{array}{l}\text { Black (10YR 2/1) clay loam; weak fine blocky structure; very friable; abrupt lower } \\
\text { boundary; common roots; }<2 \% \text { coarse fragments; common well-preserved organic } \\
\text { material; } 5 \% \text { snail shell fragments, including hydrobiidae; few faint fine mottles lighter in } \\
\text { color }\end{array}$ \\
\hline 5 & $22-23$ & $\begin{array}{l}\text { Very dark gray ( } 2.5 \mathrm{Y} 3 / 1) \text { clay loam; structureless; very friable (wet); very abrupt lower } \\
\text { boundary; < } 1 \% \text { coarse fragments; slightly lighter and much "cleaner" than Zones } 6 \text { and } 8\end{array}$ \\
\hline 6 & $20-22$ & $\begin{array}{l}\text { Very dark gray (10YR 3/1) clay; weak fine blocky structure; very friable (wet); abrupt } \\
\text { lower boundary; } 10 \% \text { coarse fragments; sagdidae snail present (terrestrial) }\end{array}$ \\
\hline 7 & $18-20$ & Same as Zone 5; abrupt lower boundary \\
\hline 8 & $14-18$ & $\begin{array}{c}\text { Same as Zone 6; very abrupt irregular lower boundary; contains weathered/burned } \\
\text { limestone gravel }(<5 \mathrm{~mm} \text { dia.); valloniidae snail present (terrestrial), } 5 \% \text { snail fragments; } \\
\text { sample: SLC-11-2 }(14-18 \mathrm{~cm}, 37.35 \mathrm{~g})\end{array}$ \\
\hline 9 & $0-14$ & $\begin{array}{c}\text { Olive brown (2.5Y 4/4) clay; moderate fine-medium blocky structure; very friable; } \\
\text { common fine carbonate filament and nodules; } 1 \% \text { coarse fragments; few fine faint redox } \\
\text { features; sample: SLC- } 11-1(8-12 \mathrm{~cm}, 59.37 \mathrm{~g})\end{array}$ \\
\hline
\end{tabular}




\section{Core 13, Site 12}

Location: Site 12 is located approximately $5 \mathrm{~m}$ northwest of Site 11, off the western end of the peninsula Remarks: Sediment is contained in bottom $4 \mathrm{ft}$ of 10 -ft core.

\begin{tabular}{|c|c|c|}
\hline Zone & $\begin{array}{c}\text { Depth } \\
\text { (cm) }\end{array}$ & Description \\
\hline 1 & $99-146$ & $\begin{array}{c}\text { Black (5Y 2.5/2) loam; stuctureless; loose (very wet); abrupt lower boundary; }<1 \% \text { coarse } \\
\text { fragments; abundant roots; } 1 \% \text { shell fragments; spongey }\end{array}$ \\
\hline 2 & $94-99$ & $\begin{array}{c}\text { Black (10YR 2/1) clay loam; structureless; loose; abrupt lower boundary; few roots; }<1 \% \\
\text { coarse fragments; aromatic and spongey }\end{array}$ \\
\hline 3 & $92-94$ & $\begin{array}{c}\text { Dark olive gray (5Y 3/2) loam; structureless; loose; abrupt lower boundary; }<1 \% \text { coarse } \\
\text { fragments; sludgey, aromatic, spongey }\end{array}$ \\
\hline 4 & $76-92$ & $\begin{array}{l}\text { Very dark grayish brown }(2.5 \mathrm{Y} 3 / 2) \text { loam; structureless; loose; clear lower boundary; } \\
\text { abundant roots; }<1 \% \text { coarse fragments; paucity of snail; } 1 \text { very well preserved fragment } \\
\text { of wood, generally organic rich; spongey texture and very wet after being exposed for } 2 \\
\text { days }\end{array}$ \\
\hline 5 & $45-76$ & $\begin{array}{c}\text { Black (7.5YR 2.5/1) clay loam; structureless; loose; clear lower boundary; contains well- } \\
\text { preserved wood fragments; } 5 \% \text { snail shell fragments, possible hydrobiidae; }<1 \% \text { coarse } \\
\text { fragments }\end{array}$ \\
\hline 6 & $26-45$ & Same as Zone 5; abrupt lower boundary \\
\hline 7 & $22-26$ & $\begin{array}{l}\text { Very dark grayish brown (10YR 3/2) clay; structureless; loose; very abrupt lower } \\
\text { boundary; few distinct fine very pale brown (10YR } 8 / 2) \text { mottles; few distinct mottles of } \\
\text { Zone 8; common fine shell fragments; } 3 \% \text { coarse fragments }\end{array}$ \\
\hline 8 & $0-22$ & $\begin{array}{c}\text { Olive brown ( } 2.5 \mathrm{Y} 4 / 4) \text { clay; moderate fine blocky structure; very friable; filamental } \\
\text { carbonates; few root pseudomorphs, gleyed with gray clay hypocoat; } 2 \% \text { coarse } \\
\text { fragments }\end{array}$ \\
\hline
\end{tabular}




\section{Chapter 3}

\section{Cultural and Archaeological BACKGROUND}

\section{Cultural Context}

Human presence in the study region is divided into three periods: Prehistoric (including Paleoindian, Archaic, and Late Prehistoric), Protohistoric, and Historic. Evidence for prehistoric occupation in and around the San Marcos Springs extends from the Clovis period, approximately 13,500 years ago, up until the arrival of Spanish explorers about 260 years ago. Historic documents record the use of the springs by Spanish and Native American groups in the seventeenth, eighteenth, and nineteenth centuries, and as early as the mid-nineteenth century by Anglo-American settlers such as General Edward Burleson.

Spring Lake is in a transitional zone in terms of cultural influences, with traits present from Central Texas, South Texas, and, to a lesser degree, the Upper Coast of Texas (Goode 1989). Patterson (1995) has synthesized the chronological evidence for Southeast Texas, including the Upper Coastal Region. The cultural chronologies for Central and South Texas are not completely understood, but recent syntheses are presented by Black (1995), Hester (1995, 2004), and Collins (1995, 2004). Dates for prehistoric periods and parts of the Protohistoric that are derived from archaeological contexts are presented in radiocarbon years before present (BP, i.e., before 1950). Dates in the historic period are based on written accounts and are given in calendar ages.

\section{Paleoindian}

The Paleoindian stage marks the earliest human occupation of North America and extends until approximately $8000 \mathrm{BP}$. According to Hester (1995:433-436, 2004), the Paleoindian period occurred between 11,200 and 7950 BP in South Texas. Collins (1995:381-385; 2004) dates it to 11,500-8800 BP in Central Texas. Diagnostic Paleoindian artifacts include Clovis, Folsom, and a variety of later types (Bousman et al. 2004). Early Paleoindian peoples are thought of as highly nomadic cultures that relied heavily on hunting large game animals such as mammoth, mastodon, bison, camel, and horse (Black 1989). Of these, all but bison were extinct by the end of Clovis times. Research shows that Paleoindians utilized a wide variety of plants and animals, such as raccoons, badgers, mice, alligators, turtles and tortoises (Black 1989; Bousman et al. 2004; Collins and Brown 2000; Hester 1983; Lemke and Timperley 2008).

A large distribution of Clovis points across North and Central America suggests a wide dispersal of their makers (Wenke 1990:201). These points are lanceolate in shape, with a thinned base resulting from "fluting," or the removal of one or more channel flakes, and are often found associated with remains of large, now-extinct herbivores. Site types include open camp sites, quarries, and caches, though kill sites are the best known. Other artifacts associated with Clovis are specialized bifaces, prismatic 
blades and blade cores, engraved stones, bone points, stone bolas, ochre, and shaft straighteners.

Clovis is followed by Folsom and Midland point types, which overlap slightly (Holliday 1997). Folsom points are fluted and are found in association with ancient bison remains, while Midland points are manufactured through pressure collateral flaking, but lack fluted channels. Very thin bifaces called ultrathin bifaces are also found at some Folsom sites (Stanford and Broilo 1981). Folsom peoples are considered to be specialized bison hunters. Most Folsom sites occur as surface scatters, although stratified deposits also occur. Artifacts associated with this interval are common throughout Texas (Bousman et al. 2004).

Archaeological evidence suggests that, with the exception of bison, large game animals were extinct in Texas after 10,000 BP. Hunters instead concentrated on deer, antelope, and other game (Bousman et al. 2002, 2004). Between 10,000 $\mathrm{BP}$ and $8000 \mathrm{BP}$, Central Texas is characterized by a series of archaeological cultures based on changing projectile point styles. Changes in the subsistence base eventually required technological shifts that mark the beginning of a new cultural period known as the Archaic.

\section{Archaic}

Collins $(1995,2004)$ dates the Archaic in Central Texas from approximately 8800 to 1200/1300 BP (other archaeologists suggest that the Archaic began at 8000 BP). Following Weir (1976), this period is divided into Early, Middle, and Late periods. The Archaic marks several important transitions: a shift from hunting large to smaller game; an apparent increase in the use of plants and the use of ground stone in food processing; implementation of stone cooking technology; increased use of organic materials in tool technologies and an increase in the number and variety of lithic tools for wood working; greater population stability and less residential mobility; and systematic burial of the dead. This stage is also distinguished by environmental and climatic changes and oscillations.

The beginning of the Holocene is marked by a significant climate change, associated with the extinction of megafauna, that stimulated many important cultural changes. Groups focused more intensively on the exploitation of local resources such as deer, fish, and plant bulbs. This dietary adjustment is evidenced by the increased number of ground stone artifacts, burned-rock middens, and tools such as Clear Fork gouges and Guadalupe bifaces (Turner and Hester 1993:246256). Early Archaic sites are thinly dispersed and are seen across a wide area of Texas and northern Mexico (Weir 1976). Hester (1995:436-438; 2004) dates the Early Archaic, characterized by Early Basal Notched and Early Corner Notched dart points, to 7950-4450 BP, while Collins (1995:383, 2004) argues that the Early Archaic spans from 8800 to $6000 \mathrm{BP}$ based on three divisions of projectile point types.

The Middle Archaic in Central Texas dates from ca. 6000 to 4000 BP (Collins 1995, 2004). Collins divides the Middle Archaic into three projectile point style intervals: Bell-AndiceCalf Creek; Taylor; and Nolan and Travis. The beginning of the Middle Archaic (Bell-AndiceCalf Creek) was a mesic period when grasslands expanded southwards into Central and South Texas; this expanding habitat attracted bison herds from the Plains. People associated with Bell-Andice-Calf Creek styles were specialized bison hunters and who maintained a tool kit specifically adapted to killing and processing bison. Points were extremely thin and broad, and were technologically elaborated in comparison with many preceding styles. The Middle Archaic in general is associated with the Altithermal, a 
prolonged period of warmer temperatures and increasing aridity. As the Altithermal progressed through the Middle Archaic, conditions in South and Central Texas became ever warmer and drier, and bison herds probably retreated northwards. Taylor bifaces were manufactured during this period; these bifaces are similar to the earlier Bell-Andice-Calf Creek point styles, but lack the deep basal notches that characterize the earlier types. By the latter part of the Middle Archaic, Nolan and Travis points predominate; both are stemmed varieties, and are technologically and stylistically dissimilar to preceding styles (Collins 1995, 2004). Temperature and aridity were at their peaks in the Nolan-Travis interval, and there is evidence of increased utilization of xerophytes such as sotol (Johnson and Goode 1994). These plants were baked in earth ovens, associated with middens of fire-cracked rock. During drier episodes of this period, the aquiferfed streams and resource-rich environments of Central Texas were extensively utilized (Story 1985:40; Weir 1976:125, 128).

The Late Archaic dates to approximately 4000-1300/1200 BP (Collins 1995:384, 2004). Bison herds began returning to the southern Great Plains (Dillehay 1974), again influencing subsistence. Cemeteries at sites such as Ernest Witte (Hall 1981) and Olmos Dam (Lukowski 1988) provide some evidence that populations increased and that groups were becoming territorial (Story 1985:44-45), though this pattern may have begun in South Texas by as early as ca. 6500-7000 BP (Ricklis 2005). Pottery, which often accompanies increased sedentism, territoriality, and population growth, began appearing in limited areas of the South Texas Plains during the Late Archaic (Story 1985). However, most regions remained "pre-ceramic" for another thousand years (Story 1985:45-47). Due to its length, several point styles characterize the Late Archaic, including Bulverde, Pedernales,
Castroville, Marcos, Montell, Fairland, Ensor, and Frio (Turner and Hester 1993:114,122). Darl points, which vary significantly from earlier Ensor and Frio styles, are not notched, but rather have elongated blades and squared stems.

\section{Late Prehistoric}

Collins $(1995,2004)$ dates the Late Prehistoric to $1300 / 1200-260 \mathrm{BP}$, and follows Kelley (1947) in dividing it into the Austin and Toyah phases. This stage is marked by the shift away from the dart and atlatl to the bow and arrow, and by the incorporation of pottery in the central and northern parts of the South Texas Plains (Black 1989:32; Story 1985:45-47). Emphasis on bison hunting during the Toyah phase was a significant factor in determining settlement and mobility patterns.

The Austin phase is characterized by small arrow points, including Edwards, Scallorn, and other types, indicating a shift from the use of atlatls to bows. Burned rock middens are sometimes associated with these types (Houk and Lohse 1993). Ground and pecked stone tools for processing plant food are common, and burials from this time sometimes reveal a high proportion of arrow-wound deaths (Black 1989; Prewitt 1974), perhaps suggesting some disputes over resource availability.

The beginning of the Toyah period ( 750 BP) in Central Texas is marked by contractingstemmed points and flaring, barbed-shouldered points. The Perdiz point is the most common example (Black 1989:32; Huebner 1991:346), and this type occasionally occurs on glass in mission contexts (Lohse 1999:268). This period is also characterized by prismatic blades, blade cores, and scrapers-on-blades. All of these tools are considered part of a specialized bison hunting and processing toolkit (Black and McGraw 1985; Huebner 1991; Ricklis 1994), yet they do not 
occur evenly across the Toyah area. The wide variety of ceramic styles and materials seen in Toyah pottery provides information on the social composition of these groups (Arnn 2005), with assemblages displaying Caddo, Texas GulfCoast, and Jornada Mogollon influences. Johnson (1994) contends Toyah culture represents a constellation of traits shared by a limited number of groups sprawled across a very large area. Ricklis (1994) describes it as a collection of traits that moved through relatively stable regional populations. Recently Arnn (2007) has argued that a large number of cultural groups, many documented by European explorers, interacted with each other over a large area, resulting in the spread of shared styles and technologies.

\section{Protohistoric (Spanish Entrada) Period}

The Protohistoric period was marked by Spanish entradas, formal expeditions into Texas in the late seventeenth and early eighteenth centuries. Hester defines the period as "the transition period between the Prehistoric and Historic period denoting a phase for which few written records are available, and for which most evidence is derived from archaeology" (1995:449-450, 2004). This period began with the venture by the Spanish explorer Cabeza de Vaca and the Narvaez expedition in 1528 and extends to the establishment of the Mission San Antonio de Valero (the Alamo) in San Antonio, in 1718 .

When the Spanish missions were established in East Texas in the late 1600s, entradas began to travel regularly through Central Texas. These expeditions provide the first detailed observations on the original Native American inhabitants of the region. With Alonso de León's expedition of 1680, El Camino Real (the King's Road) was established from Villa Santiago de la Monclova in Mexico to East Texas. This roadway followed established Native American trade routes and trails, and became a vital link between Mission San Juan Bautista in Northern Mexico and the Spanish settlement of Los Adaes in East Texas (McGraw et al. 1991).

Spanish priests accompanying entradas provided most of the available information on indigenous cultures of early Texas. The few surviving accounts of native groups in Texas reveal a dynamic cultural environment where numerous tribes passed through or inhabited Central Texas at different periods. Little is known about the majority of these tribes, but those documented around the springs at San Marcos include the Cantona, Muruam, Payaya, Sana, and Yojuane. Other tribes encountered at San Marcos included mobile hunting parties from villages in South and West Texas, such as Catequeza, Cayanaaya, Chalome, Cibolo, and Jumano, who were heading for bison hunting grounds in the Blackland Prairies (Foster 1995:265-289; Johnson and Campbell 1992; Newcomb 1993). Later groups migrated into the region, displacing the former groups or tribes. These included the Tonkawa from Oklahoma and Lipan and Comanche from the Plains (Campbell and Campbell 1985; Dunn 1911; Newcomb 1961, 1993). Archaeological sites dated to this period typically contain a mix of both European imported goods such as metal objects, glass beads, and chipped stone tools. Site $41 \mathrm{HY} 446$, recorded within a few kilometers of the Spring Lake APE, appears to contain evidence of early Historic or Protohistoric Native American remains.

\section{Historic}

Spanish settlement in Central Texas first occurred in San Antonio with the establishment of Mission San Antonio de Valero, and the later founding of San Antonio de Béxar (Bolton 1970 [1915]; Habig 1977; de la Teja 1995). Most 
knowledge of this period is gained through the written records of the early Spanish missionaries. Between 1746 and 1755, three missions, San Francisco Xavier de Horcasitas, San Ildefonso, and Nuestra Señora de la Canderlaria were located somewhere along the San Gabriel (known at the time as the San Xavier) River in present-day Milan County. The three missions were eventually coalesced into one, the San Xavier Mission, and moved to the San Marcos River in 1755. A petition to permanently establish a mission in Apache territory resulted in the founding of the San Sabá Mission, near present-day Menard, in 1757. Neophytes from the San Xavier Mission in San Marcos were transferred to the San Antonio missions and the mission's property and presidio were reassigned to the San Sabá Mission. A small group of local San Xavier Indians, the Mayeyes, persuaded the missionaries to set up a new mission for them on the Guadalupe River, to be named the San Francisco Xavier Mission, but it only lasted until 1758 (Bolton 1970 [1915]). The precise location of the San Xavier Mission along the San Marcos River has not yet been determined, but is speculated to have been on the Aquarena Center peninsula (C. Britt Bousman, personal communication 2004).

Besides the mission town of San Antonio, the only other Spanish settlement in the region was San Marcos de Neve, established in 1808, four miles south of present-day San Marcos. San Marcos de Neve was abandoned in 1812 as a result of constant raids by local tribes (Dobie 1932). During this time, massive depopulation occurred among Native Americans due to diseases to which indigenous people had little resistance. Those few remaining were gradually displaced to reservations beginning in the mid1850s (Fisher 1998).

Mexico achieved independence from Spain in 1827, opening settlements in today what is known as South Texas. European presence increased as settlers received land grants from the Mexican government until 1835. Settlement was difficult, however, due to raids by Native American groups. The Texas Rangers provided protection from these conflicts after Texas secured independence from Mexico in 1836. Settlement in the region increased until 1845, when Texas gained admission to the United States, resulting in the formation of Hays County in 1848 (Bousman and Nickels 2003).

\section{Previous Investigations}

Six archaeological sites are recorded within the vicinity of the proposed APE (Appendix E, Figure E-1). These are 41HY37, 41HY147, 41HY160, 41HY161, 41HY165, and 41HY306. Work has been conducted off and on at these sites for a number of years (Table 3-1).

Based on the results of previous archaeological investigations within and adjacent to the APE, cultural materials in good contexts are undeniably present. Deposits encountered at the base of the Balcones Escarpment are in colluvial deposits with questionable contexts. However, materials in alluvial deposits, such as on the Aquarena Center peninsula and along Sink Creek (see Figure 2-3), are intact and are known to contain isolable components. Assemblages encountered here have dated from the Paleoindian or Early Archaic periods continuously through to the Archaic and Late Prehistoric periods and even the Protohistoric and Historical eras. They have demonstrable potential for providing high-quality data that would unquestionably contribute to a better understanding of prehistoric occupations within the project area.

\section{$41 H Y 37$}

Site 41HY37, an SAL, was first recorded in 1970 by W. L. McClure as a prehistoric site 
Table 3-1. Previously Investigated Sites in the Spring Lake Vicinity.

\begin{tabular}{|c|c|c|c|}
\hline Site & $\begin{array}{c}\text { When } \\
\text { Investigated }\end{array}$ & Components & Citations \\
\hline $41 \mathrm{HY} 37$ & $1983,2000,2010$ & $\begin{array}{l}\text { Historic Burleson homestead; Late } \\
\text { Prehistoric and Late Archaic (Late } \\
\text { Archaic: Pedernales and Edgewood } \\
\text { points) }\end{array}$ & $\begin{array}{l}\text { Bousman and Nickels 2003; } \\
\text { Garber and Orlof 1984; Yelacic } \\
\text { and Lohse } 2010\end{array}$ \\
\hline 41HY147 & $1979,1990,1990$ & $\begin{array}{l}\text { Archaic, late and early Paleoindian, } \\
\text { Pleistocene fauna }\end{array}$ & $\begin{array}{c}\text { Shiner 1983; Takac 1990, 1991a, } \\
\text { 1991b }\end{array}$ \\
\hline 41HY160 & $\begin{array}{l}1982,1983,1991, \\
1997,1998,2001, \\
2002,2003, \\
2004,2006\end{array}$ & $\begin{array}{l}\text { Discrete components from Late } \\
\text { Prehistoric through Early Archaic, } \\
\text { domestic features }\end{array}$ & $\begin{array}{c}\text { Aery 2007; Nickels and } \\
\text { Bousman 2010; Garber et al. } \\
\text { 1983; Oksanen 2006; Ramsey } \\
1997\end{array}$ \\
\hline 41HY161 & $\begin{array}{l}1978,1997,1998, \\
2000,2004 \\
2008,2009\end{array}$ & $\begin{array}{l}\text { Mixed historic and Archaic, Late } \\
\text { Archaic, late and early Paleoindian, } \\
\text { human remains, Pleistocene fauna }\end{array}$ & $\begin{array}{l}\text { Ford and Lyle 1998; Garber and } \\
\text { Glassman 1992; Jones 2002; } \\
\text { Leezer et al. 2010; Lyle et al. } \\
\text { 2000; Oksanen 2008; Shiner } \\
\text { 1979, 1981, 1984; Stull and } \\
\text { Hamilton 2011; Yelacic et al. } \\
\text { 2008 }\end{array}$ \\
\hline 41HY165 & $\begin{array}{l}\text { 1984, 1996-1998, } \\
2000-2001\end{array}$ & $\begin{array}{l}\text { Prehistoric, Middle Archaic, bison, } \\
\text { historic, mixed historic, and prehistoric }\end{array}$ & $\begin{array}{l}\text { Giesecke 1998; Ringstaff 2000; } \\
\text { Soucie and Nickels 2003; Soucie } \\
\text { et al. } 2004\end{array}$ \\
\hline 41HY306 & 1999 & Late Archaic, late Paleoindian & Arnn and Kibler 1999 \\
\hline
\end{tabular}

of unknown age consisting of "arrow point fragments, miscellaneous bifacial tools, and worked flint" (McClure 1970). The site location was described to be on the hill behind (west of) the Aquarena Springs Inn (now the River Systems Institute) and overlooking the golf course to the east. A historic component was added in 1979, when Clark recorded the reconstructed two-room log home of Edward Burleson (Clark 1979). The building was originally constructed in 1848, but had fallen into disrepair and in 1964 was restored with the original chimney stones and logs from different structures that dated to the original period. Clark also noted that the structure had most likely been moved from its original location.

In 1983, the Southwest Texas State University (SWT, now called TxState) archaeological field school excavated seven $1 \times 1$-meter $(\mathrm{m})$ units and one $1 \times 2$-m unit in addition to collecting numerous surface artifacts at $41 \mathrm{HY} 37$. Soils were shallow, with bedrock encountered between 8 and $40 \mathrm{~cm}$ below surface (cmbs), and most of the more than 700 artifacts were recovered from the surface. Excavations were conducted in areas of noted surface artifact concentrations, which included a large pile of unburned rocks. Collected artifacts included sandstone manos, bifaces, preforms, reworked broken preforms, scrapers, a Clear Fork gouge, choppers, cores, 682 lithic fragments, and four diagnostic projectile points dating from the Middle Archaic to the Late Prehistoric period (Garber and Orloff 1984). Site 41HY37 is thought to reflect a number of activities ranging from hunting and hide processing to woodworking and plant processing (Garber and Orloff 1984). Archaeological site $41 \mathrm{HY} 37$ was designated an SAL on July 23, 1999 (Texas Historical Commission [THC] 1999a).

In the summer of 2000, SWT conducted an additional field school at 41HY37. The 
field school was conducted at the request of Dr. Michael Abbott, Special Assistant to the President at SWT, to study the original Edward Burleson Homestead. The objectives of the study were to determine if the original site still contained intact archaeological deposits, if the replica constructed in the 1960s was placed on the original site and foundation, and if the information provided by the excavation could be used for the accurate representation and interpretation of the site (Bousman and Nickels 2003). Archival and archaeological investigations indicated that the original location of the Burleson cabin was on the ridge above Spring Lake and that the replica structure was erected in the general location of the original cabin. An oral history in addition to the archaeological investigations indicated that replica structure was not constructed on the original foundations, and that the original foundation and chimney were used in the reconstruction (Bousman and Nickels 2003). Historical artifacts indicate that the excavation area was the general location of a mid-nineteenth-century residence. In addition to the historical component, four fire-cracked rock features were uncovered. These features were interpreted to represent prehistoric cooking ovens and/or hearths (Bousman and Nickels 2003). In total, 2,265 lithic artifacts were recovered consisting of projectile points, bifaces, unifaces, flakes, and cores. The burned rock features in addition to the recovery of a quantity and variety of stone tools imply that the site was utilized as an open campsite during the Late Archaic and Late Prehistoric period (Bousman and Nickels 2003).

A portion of $41 \mathrm{HY} 37$ was revisited by Arnn and Kibler (1999) of Prewitt and Associates, Inc., preceding the construction of an underground water line. Five backhoe trenches excavated along the base of the escarpment yielded a number of artifacts in colluvial (i.e., slope-washed) sediments. As a result, the boundary of 41HY37 was extended to the base of the escarpment (Arnn and Kibler 1999).

Site $41 \mathrm{HY} 37$ was again revisited during an intensive archaeological survey for the Spring Lake Preserve Project. This survey revisited the area of the 1983 SWT field school excavations. During the investigations of this area, a small amount of patinated lithic debitage was observed on the surface. Lithic artifacts consisted of small chert flakes or flaked chert cobbles. Additionally, a high amount of debris including plastic, paper, aluminum cans, miscellaneous pieces of metal, glass bottles, and golf balls was present in addition to many distinct piles of rubble, trash, and biomass from Spring Lake. Other recent disturbances included two unimproved roads; these have existed since at least since 1983 (Garber and Orloff 1984), and one has been modified for use as the Preserve trail system (Yelacic and Lohse 2010).

\section{$41 H Y 147$}

Investigations at the Terrace Site (Takac 1990) or Spring Lake Site (Shiner 1984) were carried out by Joel L. Shiner intermittently from 1979 until his death in 1988. The site is composed of several areas of archaeological debris located along a large submerged terrace adjacent to the western bank of Spring Lake. Primary excavations uncovered lithic materials of various ages within a deflated, mixed, 20-cm stratum (Shiner 1983). Clovis, Plainview, Angostura, and Golondrina points were found mixed with Archaic points. Faunal remains consisting of mammoth, mastodon, and bison tooth fragments were also recovered (Shiner 1983). Subsequent excavations revealed three distinct strata. The uppermost grey clay matrix varied from 20 to $30 \mathrm{~cm}$ in depth and contained Archaic points. The second layer, composed of red sand, varied from 10 to $20 \mathrm{~cm}$ in thickness and consisted of Archaic shouldered 
projectile points and earlier lanceolate styles. The last layer, containing red clay, possessed the majority of the megafauna remains in addition to Clovis, Plainview and other lanceolate points (Shiner 1983). Among the artifacts collected were a few "exotic" or nonlocal materials consisting of red-colored quartzite, terminated quartz crystals, and chert from 50 to 75 miles away. In addition several scales of alligator gar were recovered, a species far different from the local spotted gar (Shiner 1981). Shiner (1983) postulates that the presence of scrapers, large amounts of lithic chipping debris, preforms, and the broken bones of many species indicate that the site was the location of a Paleoindian base camp supporting an almost sedentary hunting and gathering existence. Johnson and Holliday (1984) refute this contention and postulate that the large quantities of lithic artifacts were a direct result of the presence of chert outcrops in the area.

In October of 1989, following Shiner's death, Southern Methodist University graduate student Paul R. Takac took possession of Shiner's notes and collections in an attempt to complete analysis of the collection and conduct additional excavations at the Spring Lake Site (Takac 1990). He conducted additional underwater investigations of $41 \mathrm{HY} 147$ in 1990 and 1991. Takac (1990), like Shiner, contends that the paleoenvironment of the Spring Lake area in addition to the abundance of raw lithic materials and a permanent, reliable water source may have supported semi-sedentary hunter gatherer groups in the past. Takac argues that the importance of readily available and diverse floral and faunal resources must be incorporated when modeling economic settlement strategies (Takac 1990). Takac also compared the Spring Lake material to the Early Archaic and Late Prehistoric lithic remains recovered by Garber et al. (1983) at the Tee Box 6 Site (41HY160). Garber noted a high incidence of usable flakes that were not utilized or modified among the Tee Box 6 materials (Takac 1990). Takac's primary analysis of the Spring Lake materials indicated a similar occurrence. Also similar to the Tee Box 6 Site, the Spring Lake Site (41HY147) contained a wide range of tool types including projectile points, scrapers, knives, drills, perforators, burins, and gouges in addition to bifacial and discoidal cores at various stages of reduction (Takac 1990). Takac's project was eventually abandoned due to the difficulty and high costs of underwater investigations. Combined, Takac's and Shiner's excavations recovered a total of 46 Paleoindian projectile points, most dating to the Late Paleoindian period. Archaeological site 41HY147 was designated an SAL on July 23, 1999 (THC 1999b).

\section{$41 H Y 160$}

Archaeological site 41HY160 was initially investigated during a field school directed by James Garber (1983) in 1982. 41HY160 is located on the peninsula between Spring Lake and Sink Creek. Garber's work was conducted in the part of the site near Tee Box 6 of the University golf course. In total, $34 \mathrm{~m}^{3}$ were excavated to varying depths, with the deepest unit excavated to $2.4 \mathrm{~m}$. Intact Late Prehistoric through Early Archaic occupations were exposed (Garber et al. 1983). The terminus of cultural deposits was not determined due to the water table. Garber et al. (1983) speculated that cultural remains are present beneath the water table level based on Shiner's recovery of artifacts from approximately 10 feet (ft) below the water surface of Spring Lake. Excavations indicated that only the upper 15 $\mathrm{cm}$ of soil were disturbed by historic processes, and that the remaining deposits were intact. Seventy-five projectile points (53 of which were identifiable) were recovered; these date to the Late Prehistoric, Late Archaic-to-Late Prehistoric transition, the Archaic, and Paleoindian periods. Late Prehistoric points such as Perdiz, Scallorn, 
Cliffton, and Alba were found between 0 and 20 cmbs; Transitional Archaic points (Darl, Fairland, and Edgewood) were recovered between 20 and 40 cmbs; Late Archaic points (Ensor, Frio, Marshall, and Castroville) were excavated between 30 and 50 cmbs; early Late Archaic points (Pedernales) occurred between 50 and $70 \mathrm{cmbs}$; and Nolan and Early Stemmed points representing the Middle and Early Archaic intervals were found between 70 and $190 \mathrm{cmbs}$. No points characteristic of the Paleoindian to Archaic transition were noted (Garber et al. 1983). In addition, 429 stone tools consisting of choppers, scrapers, cores, fine bifaces, moderately worked bifaces, crude bifaces, used-retouched flakes, and intentionally retouched flakes were also collected. Garber et al. (1983) state that the source of the chert cobbles is a limestone chert outcrop approximately one kilometer to the north of the site. It appears that tool finishing was an important activity at the site, due to the presence of over 35,000 piece of lithic debitage (Garber et al. 1983). The majority of the lithic debitage has been classified as interior flakes representing the final stages of reduction. In addition, two bone awls and one flesher (bone tool) were recovered. Three sandstone grinding slabs were found in the Late Prehistoric and Late Archaic to Late Prehistoric transition zone. Twenty-six ceramic sherds were also recovered from this zone representing Leon Plain ware and Caddoan type vessels (Garber et al. 1983). Faunal remains consisted of bison, deer, and antelope. Thirteen features were encountered and include five hearths, three stone alignments, two small burned rock middens, one posthole, one trash pit, and an area containing charcoal and pieces of fired, shell-tempered clay, possibly indicating ceramic production (Garber et al. 1983). Based on these results, this area seems to contain the intact remains from occupations dating from the Early Archaic to Late Prehistoric. The presence of Paleoindian projectile points suggests early deposits that are not yet understood. Garber et al. (1983) recommend additional investigations at the site to better understand the nature of these earlier deposits.

SWT field school participants returned to 41HY160 area under the direction of David Driver in 1991. Three units were excavated in the Tee Box 6 area, three were conducted in the vicinity of the swimming pool in front of the Spring Lake hotel (now filled in), and a seventh unit was excavated to the northeast of the anthropology field laboratory (present-day biology field laboratory) on the edge of the golf course. Units in the Tee Box 6 area were excavated to $70 \mathrm{cmbs}$. Units in the area of the swimming pool were excavated to between 50 and $160 \mathrm{cmbs}$. Most of the upper deposits near the swimming pool were mixed (James Garber, personal communication 1999), but some of the lower deposits appeared to be intact. The unit next to the anthropology laboratory was excavated to $100 \mathrm{cmbs}$. While field notes report the recovery of cultural remains from these units, excavations have not been cataloged, analyzed, or reported.

A 1993 SWT field school was conducted at Tee Box 6 of 41HY160 under the direction of David Driver. During this field school an additional six units were excavated and varied in depth from 80 to $160 \mathrm{cmbs}$. Collected artifacts include ceramic fragments, shell, lithic cores, bone, lithic debitage, points, and point fragments. These excavations have also not been fully cataloged, analyzed, or reported.

In 1997, Dawn Ramsey (1997) conducted a pedestrian survey and shovel-testing project at Aquarena Center. She excavated 10 shovel tests on the east side (left bank) of Sink Creek and northeast of the entrance road immediately east of the escarpment. All but one shovel test produced prehistoric artifacts. 
In 1998, under the direction of Kathryn Brown, participants in the SWT field school excavated six units at 41HY160 in the vicinity of the Aquarena Center buildings. Units were excavated to between 20 and 148 cmbs. Excavations were halted in most of the units when the shallow water table was reached. Intact deposits were found immediately below the present surface in two of the units. Collected artifacts include bifaces, shell, bone, lithic debitage, and points. This collection has also not been fully cataloged, analyzed, or reported. Site 41HY160 was designated an SAL on July 23, 1999 (THC 1999c).

In 1999, Prewitt \& Associates conducted a geological assessment of the Aquarean Center peninsula through the extraction of $1730-\mathrm{ft}(9-\mathrm{m})$, 3-inch-diameter cores in preparation for potential limited development by Texas Parks and Wildlife Department (TPWD) (Goelz 1999). The primary result of this work was to provide an outline of the late Quaternary geological history of the valley and the potential for prehistoric occupations. Goelz's (1999) geological assessment indicated that soil deposits are shallow near the escarpment, but quickly thicken to an average depth of $8.4 \mathrm{~m}$ in the central portion of the site. The recovery of cultural materials in such small cores is not common, and recovery usually indicates reasonably dense occupation. The majority of the core samples produced prehistoric artifacts indicating a dense concentration of artifacts in the area. Cultural materials were recovered to a depth of $6.5 \mathrm{~m}$. The estimated age for cultural materials at $6.5 \mathrm{~m}$ below the surface is $10,000 \mathrm{BP}$ (Nickels and Bousman 2010).

In 2001, an archaeological testing project was conducted as part of a master plan and partnership between TPWD and SWT to develop a public interpretive and educational center on the peninsula (Nickels and Bousman 2010). The purposes of this project were to determine the presence or absence of cultural remains in the areas to be impacted, and to evaluate the integrity of any cultural materials and determine their potential for providing significant archaeological information. Additional geological coring was conducted by the Bureau of Economic Geology, The University of Texas at Austin, in order to document the Late Pleistocene and Holocene depositional history of the valley. This produced another set of 22 cores that were extracted in two valley cross sections. Six $1 \times 1-m$ test units were excavated to an average depth of $1.7 \mathrm{~m}$. Two units were placed in the footprint of a proposed pavilion and restrooms, and four units were placed in the area of the Spring Lake Hotel swimming pool and surrounding parking lot. Samples collected from the test excavations included radiocarbon, archaeomagnetic samples of burned rock from features, and macrobotanical samples. Over 18,380 pieces of lithic material were collected, including 18 projectile points, 82 bifaces, 19 cores, two ground stones, one hammerstone, 213 unifaces, and 18,046 pieces of lithic debitage (Nickels and Bousman 2010). In addition, 2,650 fire-cracked rocks from 12 features were subjected to in field analysis, 4,388 faunal remains were collected, and 37,672 snail shells were collected. No ceramic remains were encountered. The investigation documented the presence of intact and well-stratified archaeological deposits within the upper $1.7 \mathrm{~m}$. Nickels and Bousman (2010) contended that based on the coring and also their own investigations and also previous work, intact alluvial deposits in the floodplain adjacent to the San Marcos Springs contain evidence of human occupations extending from Paleoindian to Late Prehistoric.

More recent investigations at $41 \mathrm{HY} 160$ include SWT/TxState field schools conducted in 2001, 2002, 2003, and 2006; these results have been partially reported by Aery (2007) and a 
detailed analysis is currently underway by CAS. Data recovery excavations at $41 \mathrm{HY} 160$ began after the 2001 testing project determined the potential for stratified and intact buried deposits at the site in the pecan grove area adjacent to the River Systems Institute parking lot (Aery 2007). Excavations conducted during the proceeding field schools were a result of mitigation measures to compensate for the loss of information from proposed construction in the area. The 2001 field school was supervised by Kathryn Brown and Britt Bousman, and Bousman supervised the final three seasons of this work. Excavations reached approximately $170 \mathrm{~cm}$ deep before encountering the water table. Deposits appear to span from Toyah to the Calf Creek horizon of the early portion of the Middle Archaic. At the very bottom of the block, trace amounts of Early Archaic materials were recovered, though this period was not well sampled.

In August of 2006, CAS conducted monitoring and trench inspection of 1,600 linear feet of proposed fiber optic line conduit to be placed through the Aquarena Springs Golf Course (Oksanen 2006). A segment of the line was within the boundary of $41 \mathrm{HY} 160$ in the area of Tee Box 6. The remains of three small thermal features were recorded within the localized area of Tee Box 6. The impacts to the archaeological deposits were minimal and no significant cultural deposits were encountered or disturbed. CAS recommended clearance for the conduit installation to the THC, and the THC concurred.

\section{$41 H Y 161$}

In 1840, early San Marcos settlers constructed a large log and earth dam across the San Marcos River to impound the waters for a flour mill. This dam, called the Ice House dam, impounded Spring Lake at a depth of 3-4 $\mathrm{m}$ above the natural river (Shiner 1981). In 1979, Shiner began investigations immediately below the falls of this dam, known as the Ice House Falls. Shiner found artifacts, mostly from the Middle Archaic, occurring in the sand and gravel among large cobbles at the foot of the Ice House Falls (Shiner 1979). A clay stratum approximately $1 \mathrm{~m}$ below the water level was identified on the west bank that may contain a relict portion of a site (Shiner 1979). Altogether these efforts resulted in the collection of 2,513 artifacts consisting of 1,762 pieces of lithic chips, 29 lithic cores, 201 biface thinning flakes, 141 cortex fragments, 234 flakes, and 146 tools. Tools included seven endscrapers, six side scrapers, two scrapers, six notched tools, one arrow point, 31 dart points, 51 preforms, five burins, six gravers, four borers, one drill, three scaled pieces, six gouges, 12 retouched flakes, one chopper, three hand axes, and one hammer. Projectile points included 10 Pedernales points, five Bulverde points, six Nolan points, three unidentified notched points, and four unidentified triangular points. Almost half of the collected tools consist of broken or incomplete bifaces (Shiner 1979). Shiner contends that the assemblage is reflective of hunter-gatherer groups between $1000 \mathrm{BC}$ and $3500 \mathrm{BC}$ that occupied the site for a lengthy period of time.

In the fall of 1982, SWT maintenance operations uncovered two burials in the area of the Fish Ponds on the university campus and within the boundaries of 41HY161. An emergency recovery project was conducted by Garber (Garber and Glassman 1992). Burial 1 was encountered in the sidewall of a narrow water pipeline trench at $65 \mathrm{cmbs}$. The fragmentary nature of the remains prohibited a basic osteobiographical profile. No skeletal pathologies or cause of death were identifiable (Garber and Glassman 1992). Burial 2 consisted of 45 percent of the skeletal remains of a single individual. Only four cranial fragments and the left petrous portion of the temporal bone were present from 
the cranium (Garber and Glassman 1992). Two of the recovered bones had been burned, including the right humeral fragment. The individual was identified as an adult female between 64 and 66 inches in height. No skeletal pathologies or cause of death were noted (Garber and Glassman 1992). Archaeological site 41HY161 was designated an SAL on March 13, 1987 (THC 1987).

Additional analyses of the burials recovered from 41HY161 were conducted as a part of the data recovery program conducted by CAS for archaeological site 41HY163. These remains were included to enlarge the bioarchaeological population of the San Marcos area for comparative analyses. Analyses consisted of descriptive and isotopic analysis and direct dating. These recent analyses should be considered the most accurate and current reconstruction. Less than 25 percent of Individual 1 was recovered and the remains displayed significant postmortem trauma, most likely the result of heavy equipment used during excavation. The remains of Individual 2 provided limited biological profile information. Metric analyses indicate that Individual 1 was a female, aged between 25 to 45 years, and stood between 61 and 66 inches tall (Stull and Hamilton 2011). These remains were dated to $515 \pm 20$ BP. Due to the condition of the remains from burial two, it can only be determined that this individual was an adult of indeterminate sex and stature. These remains dated to $3510 \pm 20$ BP (Stull and Hamilton 2011).

Stable carbon and nitrogen isotope data from bone collagen were also collected from the 41HY161 burials in order to reconstruct paleodietary histories of the individuals in an attempt to determine their point of origin and possible cultural affiliation (Munoz et al. 2011). The dietary data from Individual 2 indicated a subsistence strategy focused on terrestrial plants and animals with a minor contribution form riverine resources. In contrast, Individual 1 displayed dietary values suggesting a marinebased diet. This suggests that Individual 1 may have migrated inland from a coastal region (Munoz et al. 2011).

In August of 1997, the Center for Archaeological Research (CAR) at The University of Texas at San Antonio conducted an intensive archaeological survey at 41HY161 in advance of a proposed parking lot adjacent to the Ice House Mill (Ford and Lyle 1998). Investigations included pedestrian survey, backhoe trenching, and shovel testing to identify prehistoric and historic cultural remains and determine the amount of possible disturbance. Two backhoe trenches were excavated to depths of $1.2 \mathrm{~m}$ and $1.8 \mathrm{~m}$. Eleven shovel tests were excavated, with six excavated in the area of the proposed parking lot and two along the river bank. Shovel tests were excavated to a depth of $50 \mathrm{cmbs}$ whenever possible (Ford and Lyle 1998). Most shovel tests encountered modern construction or natural disturbances. One shovel test encountered prehistoric flakes and faunal remains, but these materials appeared to be in a mixed context. CAR determined that modern and historic construction has disturbed this portion of $41 \mathrm{HY} 161$.

In the spring and summer of 1998, CAR returned to $41 \mathrm{HY} 161$ to conduct subsurface testing along the proposed route of a water pipeline for SWT. The proposed pipeline included a section along the banks of the San Marcos River and sections adjacent to the Aquatic Biology Building. Investigations included excavation of 27 shovel tests, two backhoe trenches, and three test units, and monitoring of the pipeline installation (Lyle et al. 2000). Twenty-six shovel tests were excavated in three sections; Section 1 (the lawn area south of the Aquatic Biology Building), Section 2 (the 
breezeway of the Aquatic Biology Building), and Section 3 (the west lawn of the Aquatic Biology Building). The richest artifact recovery was from Section 3. Shovel tests in this location indicated an upper layer of disturbed soils over lower intact soils containing prehistoric material remains (Lyle et al. 2000). The Section 1 trench revealed an area that appears to be highly disturbed by construction and the demolition of historic buildings, while the Section 2 trench displayed disturbed soils over intact soils encountered at $100-120 \mathrm{cmbs}$. Backhoe trenches were excavated to a depth of $140-170 \mathrm{cmbs}$. As Section 3 possessed a high potential for intact prehistoric cultural remains, three test units were excavated in this location to depths between 70 and 100 cmbs. Investigations indicated that the upper 30 $\mathrm{cm}$ of deposits contained a mixture of modern, historic, and prehistoric cultural remains. Deposits between 30 and $80 \mathrm{cmbs}$ contained intact Early Archaic remains. While Paleoindian remains were encountered below $80 \mathrm{cmbs}$, the nature of the deposits was not determined.

In the spring of 2000, CAS conducted archaeological monitoring of a 200-m-long irrigation trench located adjacent to 41HY161 (Jones 2002). The area was once the location of a United States Federal Fish Hatchery that was established in 1893. Monitoring was conducted to ascertain if intact deposits were present and if so, if they would be impacted by the construction of an irrigation trench. Evidence of extensive disturbance, possibly dating from the Fish Hatchery's construction in 1893, was noted during the monitoring of trench excavations.

Between May and September of 2004, CAS conducted data recovery excavations at 41HY161. The excavations were conducted as partial mitigation for the installation of flood control measures on Sessom Creek (Oksanen 2008).
Investigations revealed intact soil deposits at $180-190 \mathrm{cmbs}$, at which point a $3 \times 4-\mathrm{m}$ block was established. Eight $1 \times 1-\mathrm{m}$ units were excavated by hand to a depth of $260 \mathrm{cmbs}$. Unit profiles indicate the development of a terrace in a slowly aggrading environment. A series of occupation zones dating from 7700 BP were identified during investigations consisting of three distinct Early Archaic occupation zones and a fourth zone containing a mixture of Early and Late Archaic materials (Oksanen 2008). This project provided information about the little-known Early Archaic period in Central Texas. The estimated age of deposits span 1,000 years, from ca. 7700 BP to $6650 \mathrm{BP}$, and identify three distinct occupational zones. The site was most intensively used during the earliest occupation. The assemblages from the earliest occupation, ca. 7700 BP, indicated that the area was utilized for the processing of large game animals, refitting of projectile points, and procuring of lithic materials. The third occupation zone, ca. $6650 \mathrm{BP}$ indicated a shift away from large game coupled with a decline in projectile points and other big game processing tools (Oksanen 2008).

CAS again conducted an archaeological monitoring of a shallow trench excavation on behalf of TxState in the spring of 2008 (Yelacic et al. 2008) to the southwest of 41HY161. The trench was excavated in order to bury waterlines supplying water to the decorative ponds around the University's Theatre Center. The trench was approximately $50 \mathrm{~m}$ long, $20 \mathrm{~cm}$ wide, and $50 \mathrm{~cm}$ at its deepest point. No cultural remains or features were noted during excavations. The deposit appeared to be disturbed by construction of the United States Federal Fish Hatchery Ponds in 1893 (Yelacic et al. 2008).

Finally, CAS conducted investigations during September 2009, in advance of the construction 
of a boiler station to be placed adjacent to the University's Jowers Center. Two test units were excavated within the proposed footprint of the building. While excavations encountered mixed historic and prehistoric deposits, these deposits were perceived as a continuation of nearby archaeological site 41HY161, and the boundaries of this site were extended to encompass these newly uncovered cultural remains (Leezer et al. 2010).

\section{$41 H Y 165$}

Site 41HY165 is located at the confluence of Sink Creek and Spring Lake on a small peninsula that extends out into the eastern half of the lake and also extends around the lake margins to the southwest. The first investigations at 41HY165 were conducted in 1984 by James Garber as part of a field school for SWT. A second field school was conducted in 1988 by David Driver and Jim Garber, and focused on testing and recording the site. Finally, three field schools were conducted on the site between 1996 and 1998 by Garber and Kathryn Brown that involved intensive testing. During the 1996, 1997, and 1998 field schools, 11 test units were excavated over the eastern portion of the site. Data from the 1996, 1997, and 1998 investigations were used as the basis for Christopher Ringstaff's masters' thesis (Ringstaff 2000). Ringstaff focused on the geoarchaeological properties of the site, but offers a relatively comprehensive study of the three field school seasons. Results from 1996 and 1997 were also used for a preliminary faunal analysis by Giesecke (1998).

Between 2000 and 2001, CAS conducted archaeological monitoring of a tree-planting project undertaken by the Department of Biology, and of the construction of the Campus Map Board along Aquarena Springs Drive (Front Door Project). While numerous prehistoric and historic artifacts were uncovered during these projects, the majority of the encountered deposits appeared in a mixed context. However, discrete areas of intact prehistoric deposits were also noted, and CAS recommended that 41HY165 be extended to incorporate these areas.

Additional prehistoric deposits associated with 41HY165 were encountered in 2003 during the monitoring of irrigation trenches for a new irrigations system on the University Golf Course. A dense deposit of lithic artifacts were recovered from an area that extends from the boundary of site 41HY165 established during the Front Door Project through the eighth green and fairwary. It was recommended again that the boundaries of site 41HY165 be extended to encompass these deposits (Soucie et al. 2004).

\section{$41 H Y 306$}

Site 41HY306 was identified during an archaeological survey and geomorphological assessment of a proposed water line near Spring Lake (Arnn and Kibler 1999). Investigators concluded that $41 \mathrm{HY} 306$ possessed stratified cultural remains in alluvial deposits representing much of the Holocene and having the potential to contribute to a better understanding of prehistoric life ways (Arnn and Kibler 1999). Cultural remains were recovered from two levels: above $1.5 \mathrm{~m}$ and below $2.5 \mathrm{~m}$. Although no diagnostic materials were recovered, it was suggested that the lower deposits may be of Early Archaic or Paleoindian age, while the upper deposits are of a Late Archaic age (Arnn and Kibler 1999).

Additional prehistoric deposits attributed to site $41 \mathrm{HY} 306$ were also encountered during monitoring of trench excavations associated with the installation of a new irrigation system on the University Golf Course (Soucie et al. 2004). Prehistoric lithic deposits were encountered along the first fairway and adjacent to Bert Brown Road at its juncture with Sink Creek. The boundaries of 
site 41 HY306 were recommended to be extended to encompass these newly uncovered deposits (Soucie et al. 2004).

\section{Summary}

Based on the results of previous archaeological investigations within and adjacent to the APE, cultural materials in good contexts are undeniably present. Archaeological remains encountered at the base of the Balcones Escarpment appear in colluvial deposits with questionable contexts. However, materials found in alluvial deposits, such as those encountered on the Aquarena Center peninsula, along Sink Creek, and throughout most of the current APE (see Figure 2-3), represent the most intact contexts and have the highest potential for isolable archaeological components. Components and assemblages encountered in these areas have the potential to date from the Paleoindian or Early Archaic through the Archaic and Late Prehistoric periods, even into the Protohistoric and Historical eras. These deposits provide the greatest potential to provide high-quality data sets that would contribute to a better understanding of prehistoric occupations within the project area. 


\section{Chapter 4}

\section{Methods}

In order to fully assess the APE for adverse effects to cultural resources, CAS conducted archaeological investigations to determine the presence and, to a degree, nature of prehistoric deposits. The current undertaking includes the removal of all submerged structures and the restoration of aquatic habitats throughout the Spring Lake peninsula, meaning that the process of assessing the APE for these deposits requires both standard terrestrial and underwater investigations of the locations where proposed impacts and modifications will occur. As previously noted and described in more detail in Chapter 5, known trinomials in the APE have never been completely surveyed or delineated prior to this undertaking. Consequently, these efforts focused on identifying the distribution of remains across the entire APE with the understanding that newly encountered deposits are associated with one of the previously recorded SALs and do not represent new sites. Results of this survey are used to define ASAs within existing SALs; these are discussed in detail in Chapter 6.

\section{Terrestrial Investigations}

CAS conducted an archaeological assessment of the SLAERP APE in order to determine existing boundaries for previously recorded sites, and to assess the horizontal and vertical distribution of cultural resources that may occur outside of established site boundaries within the APE (see Figure 1-2). The methods for the terrestrial investigations were designed to correspond with available project design work that indicated the location(s) and nature(s) of proposed impacts. For instance, the removal of nonlocal grasses across the APE constitutes a shallow impact, whereas deeper impacts (e.g., lift stations) are proposed only for specific locations. All proposed impacts were addressed by some combination of shovel tests $(n=196)$, backhoe trenches $(n=4)$, mechanical auguring $(n=1)$, and hand-excavated units $(n=3)$.

A 100 percent pedestrian survey was conducted of the APE augmented by shovel tests, followed by $1 \times 1-\mathrm{m}$ test units, a single auger excavation, and backhoe trenches. The pedestrian survey involved the visual inspection of surface areas along transects lines. Transect lines were spaced no more than $15 \mathrm{~m}$ apart in areas identified for vegetation removal and soil preparation. All artifacts that were encountered on the surface during the survey were plotted and collected, including the location of diagnostic artifacts. Shovel test excavations were then used to determine the presence of and evaluate the horizontal and vertical extent of cultural deposits down to a meter below the surface. These probes were spaced as evenly as possible across the APE and were excavated to a meter in depth except where sterile sediments, bedrock, impenetrable strata, or the water table were encountered. The excavation of three test units focused on areas possessing buried deposits identified during shovel test excavations. These areas contained dense, stratified deposits, and/or were particularly near the ground surface. Backhoe trenches were 
excavated to assess the stratigraphy, integrity, and potential for buried resources in selected locations on the Aquarena Center Peninsula. The mechanical auger was excavated to examine the proposed location of a lift station at depths that could not be reached through other means. Each of these activities is described in detail below.

\section{Shovel Tests}

CAS systematically excavated by hand 196 shovel tests in areas to be subject to exotic vegetation removal and soil preparation, and that are to be impacted through their use as routes of site access during construction and demolition. Impacts during vegetation removal and soil preparation are anticipated to be no more than $1 \mathrm{ft}(30 \mathrm{~cm})$ in depth, affecting primarily those deposits on the surface or that are shallowly buried. Shovel tests were spaced approximately $15 \mathrm{~m}$ apart due to the dense nature of previously identified deposits within the APE, yielding a clear picture of the horizontal distribution of cultural materials on the peninsula. Each shovel test was excavated in arbitrary $10-\mathrm{cm}$ levels to a depth of $100 \mathrm{cmbs}$ or to sterile soil or impenetrable clay layers. All excavated sediments were passed through 1/4-inch hardware screen. All artifacts were collected by the level from which they were encountered. Horizontal and vertical information as well as soil composition and stratigraphic information were recorded on standardized shovel test forms. All shovel test locations were recorded with a hand-held submeter accurate GPS unit and plotted on a universal map of the Spring Lake area.

\section{Test Units}

Three $1 \times 1-\mathrm{m}$ test units were excavated in locations identified during shovel test excavations as containing intact, stratified, and/or clearly definable cultural components. The primary purpose of the testing program was to map out the locations of deposits, and identify cultural deposits that may be located between previously recorded sites and in areas that have never been subjected to survey. Following the requirements of the MOA, data from these test units is used to develop detailed information regarding the nature of deposits in areas not previously subjected to extensive excavation. All units were excavated to a depth of $150 \mathrm{cmbs}$ or until bedrock or the water table was encountered. A 5-gallon bucket of soil was collected from each excavated level and water screened through nested $1 / 4$-inch and $1 / 8$-inch screen in order to recover small-sized cultural materials and faunal remains. A 4-liter bulk soil sample was also collected from each unit level. These samples were processed by flotation for the recovery of small fauna, plant remains, and lithic debris that would pass through the $1 / 8$-inch screen. All remaining excavated soils were screened through 1/4-inch screen. Encountered artifacts were collected and their vertical and horizontal locations mapped. Profiles were recorded for at least two walls of each unit.

All excavations were recorded on standardized unit-level forms, and photographs were taken to provide additional recording of the excavations. All unit locations were recorded with a hand-held submeter accurate GPS unit and plotted on a universal map of the Spring Lake area. Back dirt was returned to the units after each unit excavation was completed. Units were surrounded by orange plastic mesh (snow fencing) daily and were covered by plywood boards at night to prevent animals from accidentally falling into the units.

Data from these units complement that from the shovel tests in assessing the integrity and significance of cultural deposits. Results are also used to develop recommendations concerning how these deposits might be avoided or protected during the undertaking, or for appropriate 
mitigative efforts to offset the loss of important cultural information that will result in the event that the deposits cannot be avoided

\section{Backhoe Trenches}

Four backhoe trenches were excavated in areas with the potential for deeply buried intact cultural deposits that were more extensive than could be understood by additional shovel testing or $1 \times 1-\mathrm{m}$ units. Trenches varied in length from 3 to $6 \mathrm{~m}$ and from 1 to $2 \mathrm{~m}$ in depth. Width also varied, as trenches exceeding $1.5 \mathrm{~m}$ in depth were benched or stepped back for safety. In addition to assessing cultural deposits, these trenches also allowed geomorphic analysis to interpret stratigraphy, depositional history, and natural processes that have affected soil deposition on the Aquarena Peninsula. Examining depositional histories is a useful aid for reconstructing the sequence of cultural and natural events that contributed to site build-up and preservation. Intact cultural deposits encountered during backhoe trench excavations were mapped and recorded.

\section{Auguring}

An augur pit was excavated in the location of a proposed lift station to be located approximately $35 \mathrm{~m}$ to the east of the Skyline Pavilion Ride. The proposed depth of this lift station is approximately $12 \mathrm{ft}$, which easily exceeds any depth that can be safely reached through manual excavation or backhoe trenching. This auger was carefully monitored to assess the location for deeply buried cultural deposits. The pit measured $38.1 \mathrm{~cm}$ in diameter and $431.8 \mathrm{~cm}$ deep. This excavation took place at the western edge of the parking lot beneath a very large cottonwood tree, in the center of the western end of the peninsula. To the best degree possible, sediments were excavated in 61-cm (2-ft) levels, and approximately 50 percent of the sediment from each level was sampled for screening and description. Screened sediment was passed through $1 / 4$-inch hardware mesh, and sediments were characterized by color, texture, and inclusions. Given the method of excavation and the amount of moisture, description of structure and other soil characteristics (e.g., pores, coats, carbonates, etc.) were not possible. Depth measurements were obtained by tape measure and are less accurate with depth, especially beyond the water table, which was encountered at approximately $144.78 \mathrm{cmbs}$.

\section{Underwater Investigations}

In addition to the terrestrial investigations described above, CAS conducted underwater investigations in the areas where impacts are proposed. Specifically, these locations include areas surrounding (in front of and behind) the Submarine Theatre (sub), which is to be removed by yet-unspecified means, and submerged land formations at the far western end of the peninsula adjacent to the Landing where a concrete boat ramp is to be installed. Underwater investigations included two reconnaissance-level surveys, extraction of sediment cores, and excavation of a test unit.

\section{Reconnaissance}

Two reconnaissance-level underwater surveys were conducted, one examining the sub area and one examining the extent of lake bottom cultural deposits in areas that will be included in the APE. The goal of investigations around the sub were to determine the physical relationship between the sub and the bottom and banks of Spring Lake to ascertain if removal of the sub had the potential of impacting intact cultural resources that might be present in these sediments and alluvial landforms. These investigations consisted of a visual inspection and photographic documentation of the sub's physical location 


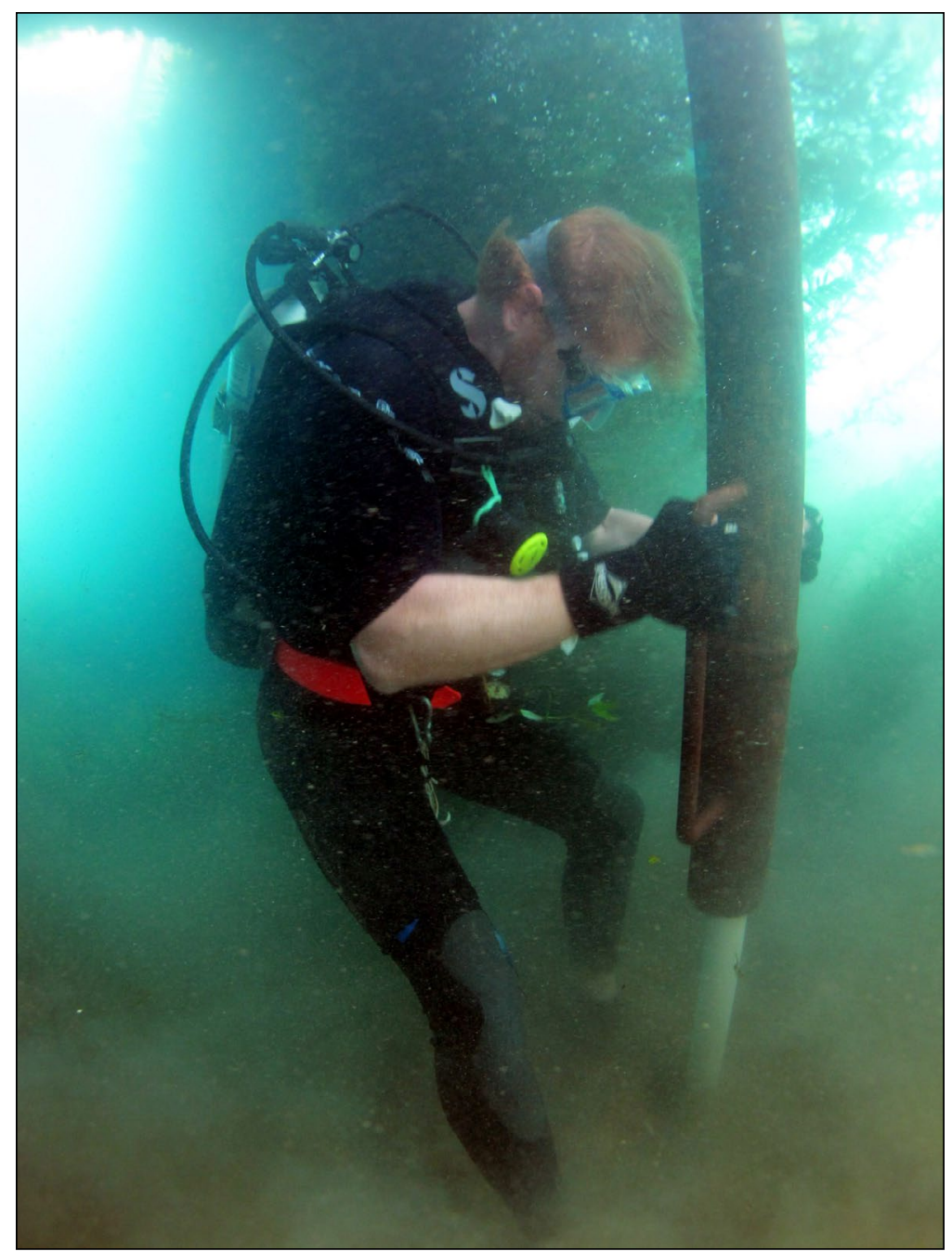

Figure 4-1. CAS archaeologist using post-driver to insert PVC pipe into lake bed sediments.

with respect to the lake bed and adjacent banks. (It was speculated prior to this reconnaissance investigation that the sub was not in contact with the lake bottom and thus its removal would not impact the surrounding sediments.)

The second reconnaissance-level underwater assessment examined the lake bottom of the upper Spring Lake area. The goal of this investigation was to identify locations on the lake bottom where cultural materials were clearly visible. This was accomplished through a series of dives in which lake bottom deposits were visually identified and charted on a map of the lake. Specific areas that were examined included not only the area around the sub, but also those between the sub location and the Landing, where project design plans currently call for a boat ramp to be installed so that the sub can be removed in sections by use of a barge.

\section{Coring}

Alluvial deposition processes and chronologies were investigated around the sub and also adjacent to the Landing for the purpose of determining whether intact strata were present in these locations that have or had the potential of containing archaeological materials. Alternatively, if analysis shows all strata in these areas to be mixed, heavily disturbed, or entirely modern, the general vicinity would have minimal potential for containing archaeological deposits that could merit further consideration during this undertaking. Working with Underwater Archaeologist Frederick Hanselmann (now of TxState) and following extensive research into subaqueous sediment coring methods, CAS archaeologists used a series of $2 \frac{1}{4}-$-inch PVC pipes in lengths ranging from 5 to $10 \mathrm{ft}$ in length. Sediment cores were acquired by driving a section of PVC pipe into lake bed sediments with a heavy-duty (ca. 30 lb) post driver (Figure 4-1). PVC pipes were removed either manually through physical force or, in the case of longer sections, through the use of a shallow draft barge with an A-frame wench 


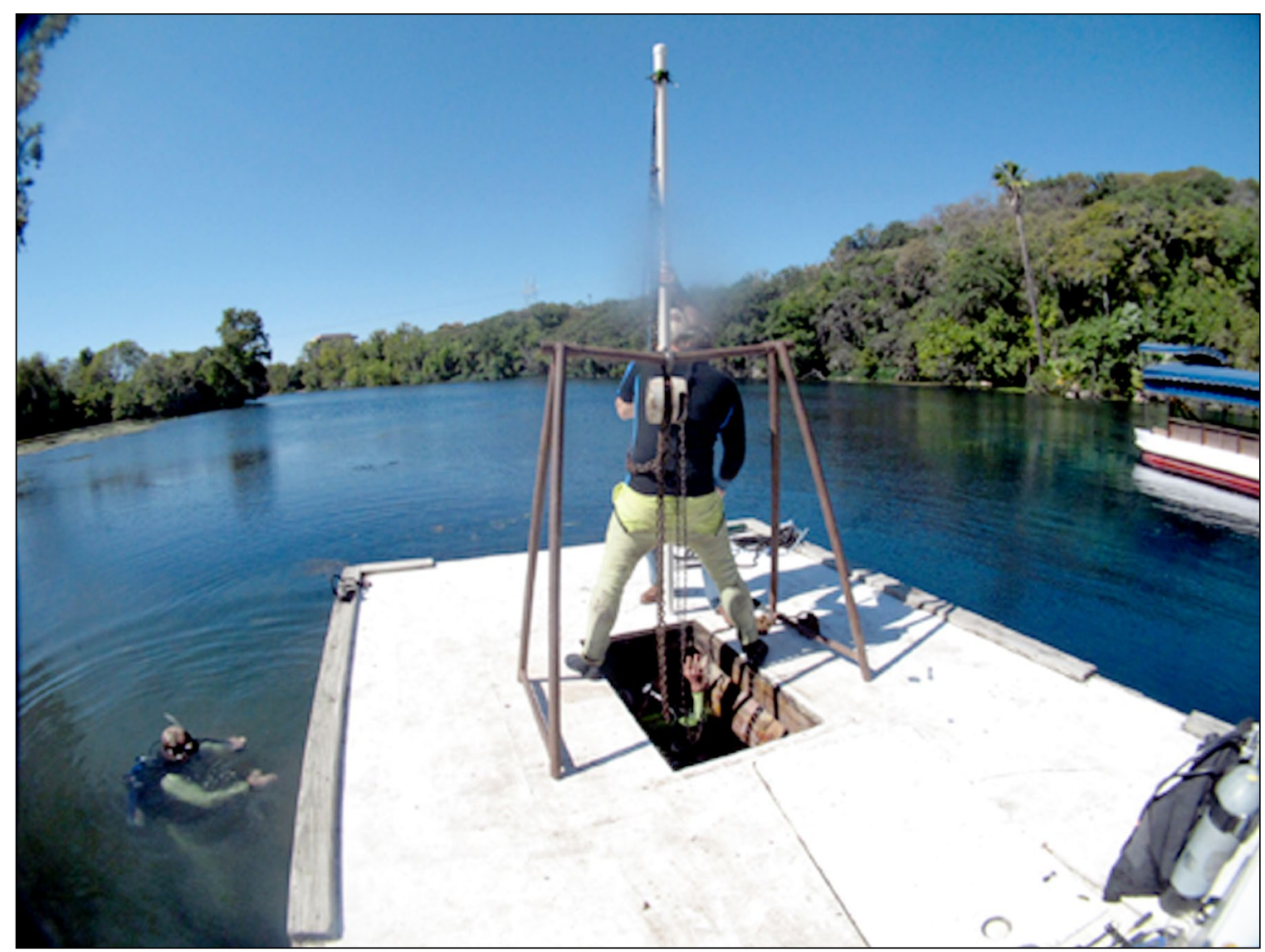

Figure 4-2. Extracting 10 foot-long cores with barge and A-frame wench.

system set up over a moon window in the barge floor (Figure 4-2).

During this phase of the underwater assessment, 12 cores were extracted, 10 of which were preliminarily assessed for geoarchaeological data to make recommendations about the likelihood of underwater deposits and potential impacts. Eight of the 10 analyzed cores were removed from around the sub; prior to the removal of any of these, modern pea gravels (deposited in modern times in an effort to prevent lake bed sediments from being stirred up during underwater performances) were first removed and samples were extracted from the sediments layers lying immediately below this deposit. Two cores were removed from near the Landing in areas that did not contain this modern stratum. In addition to descriptions from these 10 cores, a number of samples were selected from key stratigraphic points and submitted for dating.

\section{Test Unit}

An additional examination of sediments in front of the sub included a $50 \times 50-\mathrm{cm}$ test unit that was excavated to a depth of approximately $150 \mathrm{~cm}$ below the lake bottom. This test unit was excavated using an airlift and standard excavation tools (Figure 4-3); sediments were not screened for artifact recovery.

\section{Documentation and Laboratory Procedures}

\section{Mapping}

Locations of all shovel tests, test units, auger unit, backhoe trenches, and core extraction 


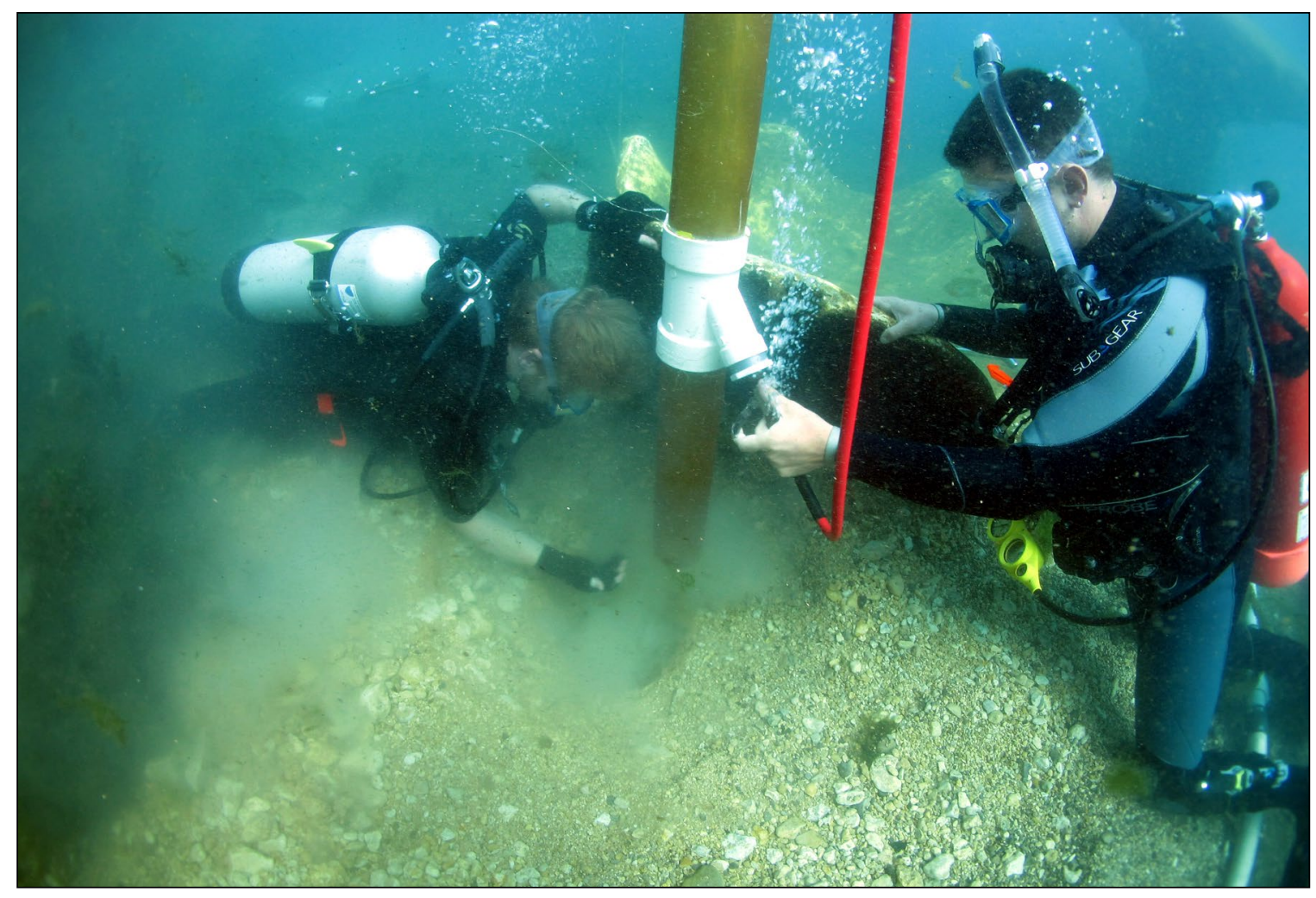

Figure 4-3. Underwater archaeologists using air lift to excavate test unit.

locations were recorded with a hand-held submeter accurate GPS unit. GIS information was then downloaded into a universal map of the overall project area.

\section{Recording}

All artifacts, samples for radiometric dating, botanical remains, and faunal samples encountered during this work were carefully collected and immediately stored in appropriate packaging (aluminum foil, plastic vials, and ziplock bags, with padding and protection as necessary) in order to maintain their integrity for later analysis and eventual storage. All collected materials were removed from the work site and returned to the CAS lab facility on a daily basis to ensure their safety and complete processing as fieldwork commenced. Comparisons were made between field inventory sheets and items processed in the laboratory to ensure accurate artifact coding. Artifacts were cleaned, sorted, and labeled, entered into a searchable database, and were subjected to the appropriate sampling and analysis procedures. All collected materials were given unique lot numbers by provenience, and were labeled with this number in addition to associated provenience information. All materials were prepared for permanent curation at the Archaeological Curation Facility at CAS.

\section{Curation}

All artifacts and records from this project will be curated at the Archaeological Curation Facility at CAS. Curation methods met or exceeded the requirements of the THC and the CTA. Collected artifacts were labeled, as necessary, with all pertinent information and placed in 4-mil ziplock bags. A field specimen inventory sheet was used 
to record all collected artifacts. This information was then entered in to a computerized database for inventory and analysis purposes. All artifacts were properly washed, analyzed, and stored until the project was completed.

Photographic logs were maintained for proper identification of all photographs. Digital images were maintained on CD-R discs with a gold metal reflective layer (phthalocyanine) and accompanied by a photo contact sheet displaying all photographs. The discs were labeled with the project number/name and date. All field maps, notes, and forms, laboratory materials, photographs, and any written documentations were curated in compliance with the standards of the THC and CTA. 


\section{Chapter 5}

\section{Results}

This chapter presents the results of terrestrial (subsurface survey and testing) and underwater (reconnaissance survey and coring) investigations of the APE. Terrestrial archaeological investigations consisted of pedestrian survey augmented by shovel tests, limited test units, an auger unit, and backhoe trench excavations. Underwater investigations included limited reconnaissance survey and extraction of sediment cores (see Chapter 5 for Methodology).

\section{Results of Terrestrial Investigations}

\section{Shovel Test Excavations}

The APE for the current undertaking was divided into three sections (Figure 5-1), Sections I, II, and III. Section I is location on the hillside bank on the northwest side of Spring Lake. The area is $75 \mathrm{ft}(22.86 \mathrm{~m})$ wide and extends from the River Systems Institute building to the parking lot of the Saltgrass Steak House Restaurant. Section

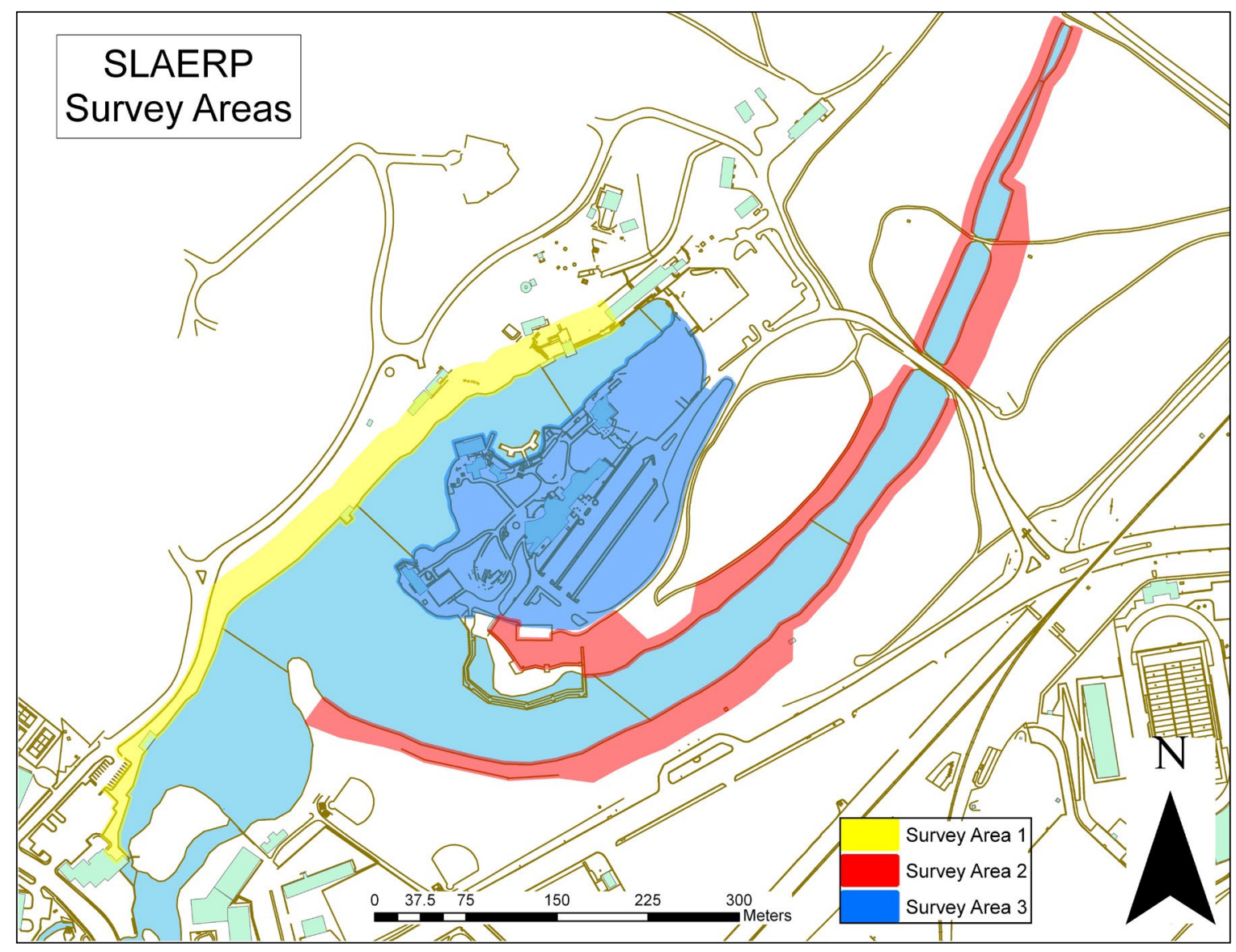

Figure 5-1. Spring Lake Section 206 Aquatic Ecosystem Restoration Project sections. 
II encompasses the APE along Sink Creek and varies between $20 \mathrm{ft}$ and $75 \mathrm{ft}(6.09 \mathrm{~m}$ and 22.86 $\mathrm{m})$ wide. This area extends along both banks of Sink Creek from its confluence with Spring Lake, through the university Golf Course, and ends at Bert Brown Street. Section III consists of the Aquarena Center buildings, grounds, and parking lots.

\section{Section I}

Section I, consisting of 2.99 acres, is characterized as a steep, sloping area along the northwestern side of Spring Lake. The area was once part of the Aquarena Springs Amusement Park and today contains trails leading to a River Walk, Grist Mill, Alligator Exhibit, Artist Studio, Sky Spiral, reconstructed Spanish Mission, Sky Ride, and a reconstruction of the Burleson Home. The trails and the former park attractions are now abandoned and overgrown with vegetation. The area is dense with tree and lower story undergrowth. Site 41HY37, a registered SAL, lies approximately $30-50 \mathrm{~m}$ to the northeast of Section I; this site will not be impacted by proposed modifications. Another SAL, 41HY161, lies to the southwest of Section I, is also outside the APE, and will not be impacted (See Appendix E, Figure E-2).

Shovel tests within Section I were excavated approximately $15 \mathrm{~m}$ apart (where possible) in relatively flat surface areas (areas with less than 20 percent slopes) (see Appendix D, Figure D-1). These areas were generally situated along an upper ridgeline along the northwestern boundary of the APE and along the lake side. Thirty-one shovel tests (ST01 through ST31) were excavated in Section I. Shovel tests were excavated to an average depth of $40 \mathrm{cmbs}$, where bedrock was generally encountered.

In total, 410 artifacts were collected from shovel tests in Section I. These artifacts consist of bone, building materials, charcoal, ceramics, glass, lithics, metal, organics, shell, and other. Collected building materials include concrete and asphalt; most of these materials are historic or modern in age. A ceramic wastewater pipe fragment, fragments of a flower pot, and floor tile fragments were also collected, in addition to fragments of vessel-shaped glass and bottles. These artifacts, including metal nails, pull tabs, a washer, metal scrap, and various types of plastic fragments, are most likely associated with prior use of the area as an amusement park. Three pieces of faunal bone were recovered, but only one (from ST17) was identifiable to species (deer). Organics included a wood fragment and two pecan nut shell fragments. Collected shell artifacts mostly included terrestrial snails. Lithic artifacts included four fragments of fire-cracked rock, five pieces of chert debitage, and one biface tool (possibly a scraper and/or graver; Figure $5-2)$.

Modern artifacts recovered from shovel test excavations in Section I are indicative of recent use of the area as an amusement park. Prehistoric artifacts consisting of lithic debitage and a possible scraper/graver were collected from the bottom of the sloping hillside of Section I and most likely represent down wash from the upper area of the hillside, where site $41 \mathrm{HY} 37$ is located. The boundaries of $41 \mathrm{HY} 37$ lie outside the APE and the site will not be impacted by proposed construction. Based on these results, no new or unknown archaeological sites or cultural deposits were encountered in Section I. CAS will recommend that construction/demolition in this area proceed as there is a low probability that intact cultural deposits will be impacted.

\section{Section II}

Section II includes 5.55 acres and is a level grassy area along the banks of Sink Creek. The majority of this section is within the university 


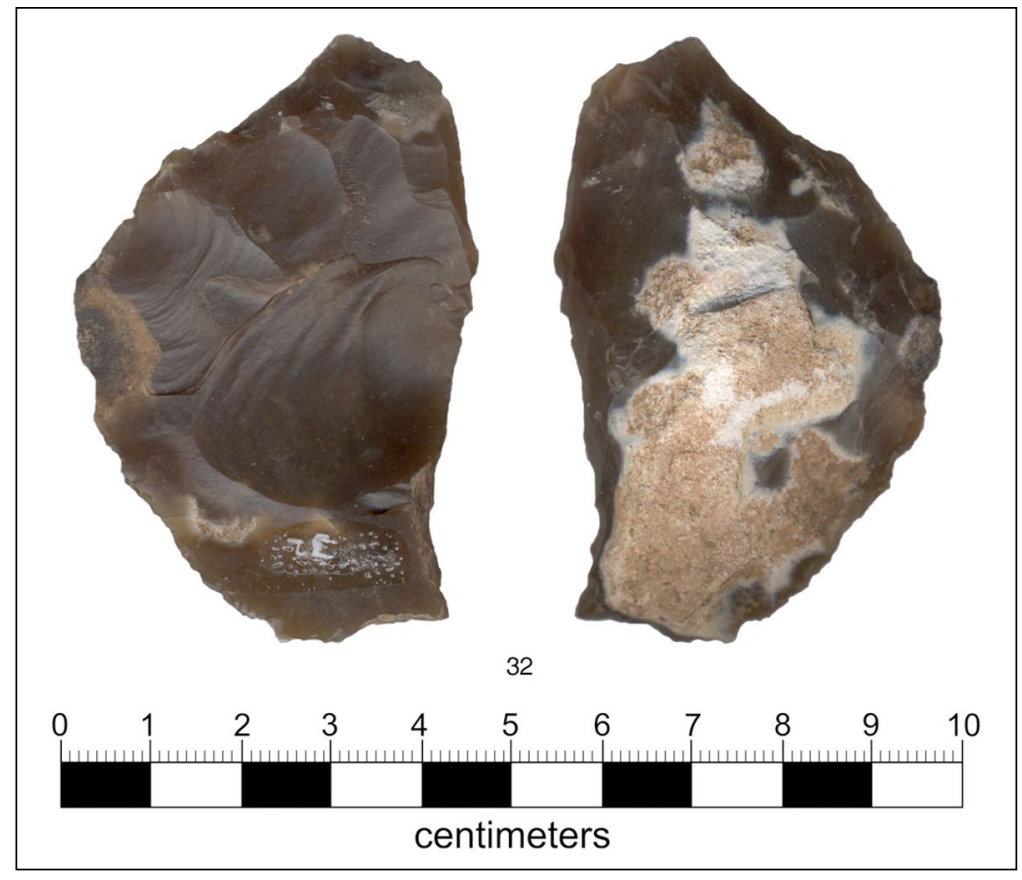

Figure 5-2. Possible scraper/graver recovered from ST31 in Section 1.
In total, 1,123 artifacts were collected during investigations in Section II. Artifacts were classified as bone, building material, charcoal, ceramic, glass, lithic, metal, organic, personal item, shell, and other artifacts. The majority of bone collected consisted of unidentifiable faunal remains; however, a fish scale (from ST132) and turtle shell fragment (from STS) were identified. Fragments of asphalt and brick collected were classified as building material. The majority of collected glass consisted of shaped bottle fragments. Metal fragments consisting of hardware, barbwire, scrap,

Golf Course property, with a smaller portion located adjacent to the East Athletic Fields and the Visitor Information Kiosk on Aquarena Springs Drive. A portion of site 41HY165, an SAL, lies within Section II (see Appendix E, Figure E-2). The area located within the TxState Golf Course contains medium-tall dense grasses, while the area next to the Information Kiosk and the East Athletic Field contain short grasses and dense tree and lower story undergrowth.

Shovel tests in Section II were excavated approximately $15 \mathrm{~m}$ apart along the edge of Sink Creek (see Appendix D, Figure D-2). In total, 119 shovel tests (ST32 through ST141, STN, STE, STW, STS, STNE, STNW, STSE, STSW, and STCENTER) were excavated in this section. Shovel tests were excavated to an average depth of $50 \mathrm{cmbs}$, at which point impenetrable clays were encountered. Many units encountered the water table between 20 and 30 cmbs; excavations continued in these cases to impenetrable clays. and pull tabs were also collected. Modern items consisted of plastic fragments and a pocket knife. Several bivalve shell fragments and snail shells were found in addition to organics, including wood, burnt wood, and pecan shell fragments. Lithics consisted of fire-cracked rock, chert chunks, debitage, bifaces, tools, and point fragments.

Building materials, ceramics, glass, metals, and plastic indicate modern or historic deposits; much of this recovery occurred adjacent to the Information Kiosk. Prior investigations in this area were conducted by CAS in 2000 and 2001, and found that "a single structure that appears to be a small house can be seen on a 1911 map of the area; the house appears to be in the immediate location of the Front Door Project" (Soucie and Nickels 2003:15). During the current investigation, a well and concrete slabs were also noted, corresponding to structures identified during the Front Door Drive Project. The historic 


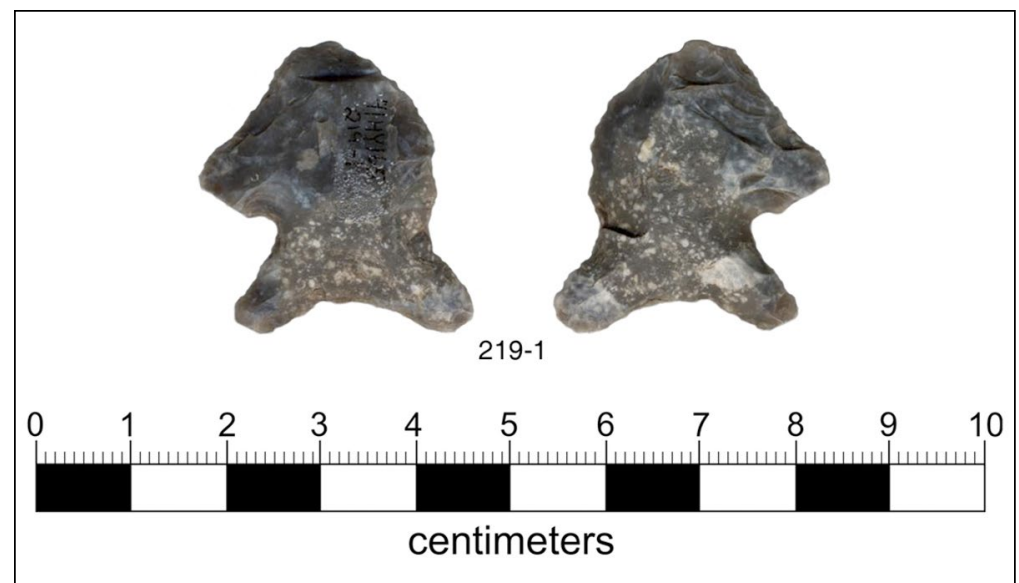

Figure 5-3. Possible Fairland point recovered from surface near eighth green.

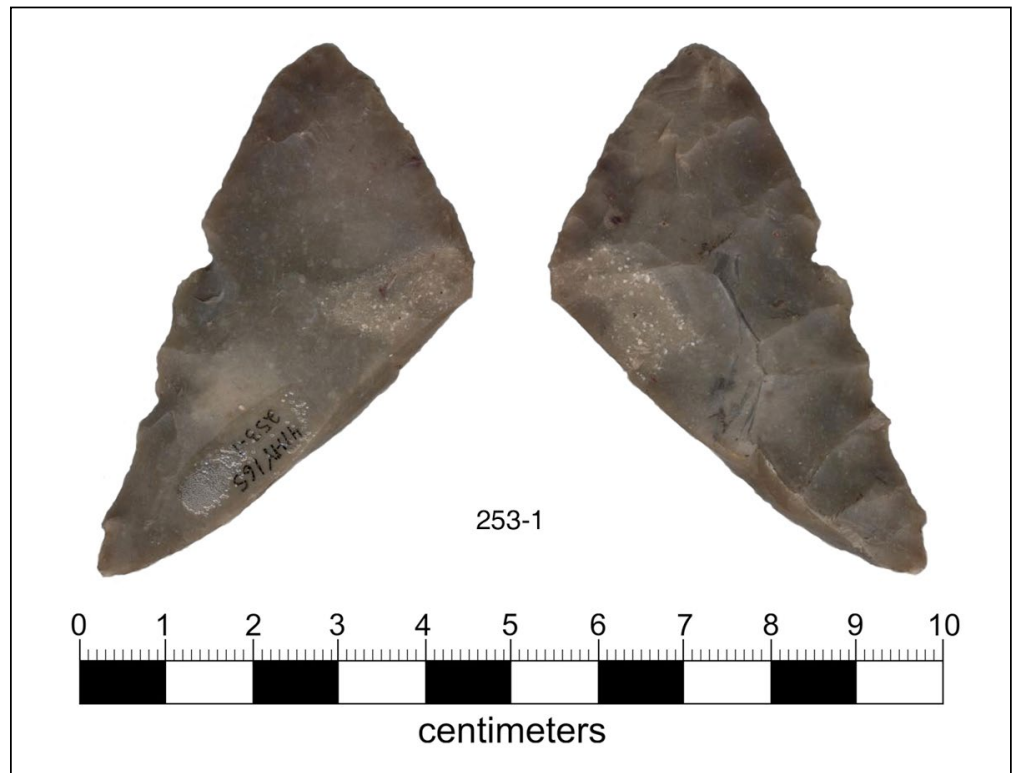

Figure 5-4. Biface fragment recovered from ST135 in the far western portion of Section II.

and/or modern debris recovered from the "Front Door" area during the current investigations most likely represent historic occupations of this area as noted by previous investigations.

The majority of collected lithic materials were recovered along the southern side of Sink Creek. This area extends from adjacent to the TxState Golf Course's eighth green along the banks of Sink Creek through the Front Door
Drive area, and follows along the East Athletic Fields ending at the small peninsula area extending into Spring Lake. Surface lithic scatter deposits were also noted in this area, including a possible Late to Transitional Archaic Fairland point found next to the eighth green (Figure 5-3) and other artifacts adjacent to the fence line between the Athletic Field and Sink Creek. Much of this area is within recorded SAL $41 \mathrm{HY} 165$.

The surface lithic scatter may correspond to prehistoric lithic debris that was noted during monitoring of irrigation trenching in the area of the eighth green in 2000 (Soucie et al. 2004), and also to deposits identified during the Front Door Drive Project conducted by CAS in 2000 and 2001 (Soucie and Nickels 2003). During the irrigation project, a trench was excavated along the eighth fairway, and a concentration of prehistoric lithic artifacts was noted along the length of this trench. During the current investigations, an extension of this deposit was encountered both on and below the surface extending from the eight green towards Sink Creek. This material continued from the eighth green through the area adjacent to the Visitor Information Kiosk, and also from the East Athletic Fields and Sink Creek to the end of the southern peninsula bordering the confluence of Sink Creek and Spring Lake (Figure 5-4). 
These prehistoric deposits are considered to be an extension of 41HY165. Both previous investigations within Section II (Front Door Drive Project and GolfCourse Trench Monitoring Project) identified these deposits as an extension of 41HY165 and recommended redrafting that site's boundaries to encompass these deposits.

\section{Section III}

Section III consists of 8.66 acres and is located on the peninsula with the Aquarena Center structures and parking lots. All of Section III lies within the boundaries of SAL 41HY160 (see Appendix E, Figure E-2). The area is characterized by level, mowed grass with large native and nonnative trees. It is bounded on the north and west sides by Spring Lake and Sink Creek, and on the southern and southeastern sides by the TxState Golf Course. The parking lot for the River Systems Institute lies to the northeast.

In total, 54 shovel tests (ST142 through ST196) were excavated approximately every 15 $\mathrm{m}$ surrounding the Aquarena Center structures and parking lots (see Appendix D, Figure D-3). These probes were excavated to an average depth of $60 \mathrm{cmbs}$, where impenetrable clays were generally encountered. Shovel tests located in close proximity to Spring Lake and Sink Creek generally encounter the water table between 20 and $30 \mathrm{cmbs}$; these tests continued until impenetrable clays were encountered or to a meter in depth.

In total, 400 artifacts were collected from shovel tests in Section III. Artifacts were classified as bone, building material, charcoal, glass, lithic, metal, organic, personal items, and shell. Building materials include fragments of brick and tile, while bone consisted of faunal remains. The glass classification contains vessel and window glass, in addition to glass marbles. Metals consisted of hardware, nails, a coin, scrap metal, and bottle caps and pull tabs. Organics included wood and seed fragments, while artifacts classified as other generally consisted of plastic fragments. A pair of earrings were recovered and classified under personal items. Snail shell composed the majority of the shell material. Artifacts classified as building materials, glass, metal, other, and personal items represent modern use of the area as an amusement park.

Approximately 160 lithic artifacts were collected from shovel tests in Section III. These include biface fragments $(n=4)$, cores $(n=2)$, debitage $(n=79)$, fire-cracked rock $(n=69)$, and projectile points $(n=2)$ (Figure 5-5). One projectile point (416-1) is a probable Darl and the other (421-1) resembles an Ensor type. Four pieces of gravel and/or pebbles were also collected. Recovered lithic artifacts indicate prehistoric occupations of the area. Shovel tests encountered prehistoric lithic deposits in locations adjacent to the Aquarena Center structures and parking lots, indicating that dense concentrations of prehistoric cultural deposits are most likely located along an area encompassing the central portion of the peninsula. Locations of dense prehistoric deposits identified during shovel tests were further examined through the excavation of $1 \times 1-m$ test units and backhoe trenches.

\section{Test Unit Excavations}

Three test units were excavated to further explore prehistoric deposits identified during shovel test excavations of Section II and Section III. Two test units (XU01 and XU02) were excavated within Section III (see Appendix D, Figure D-4), and one test unit (XU03) was excavated within Section II (see Appendix D, Figure D-5).

\section{XU01 and XU02}

Both XU01 and XU02 were located and excavated within Section II. These units were 


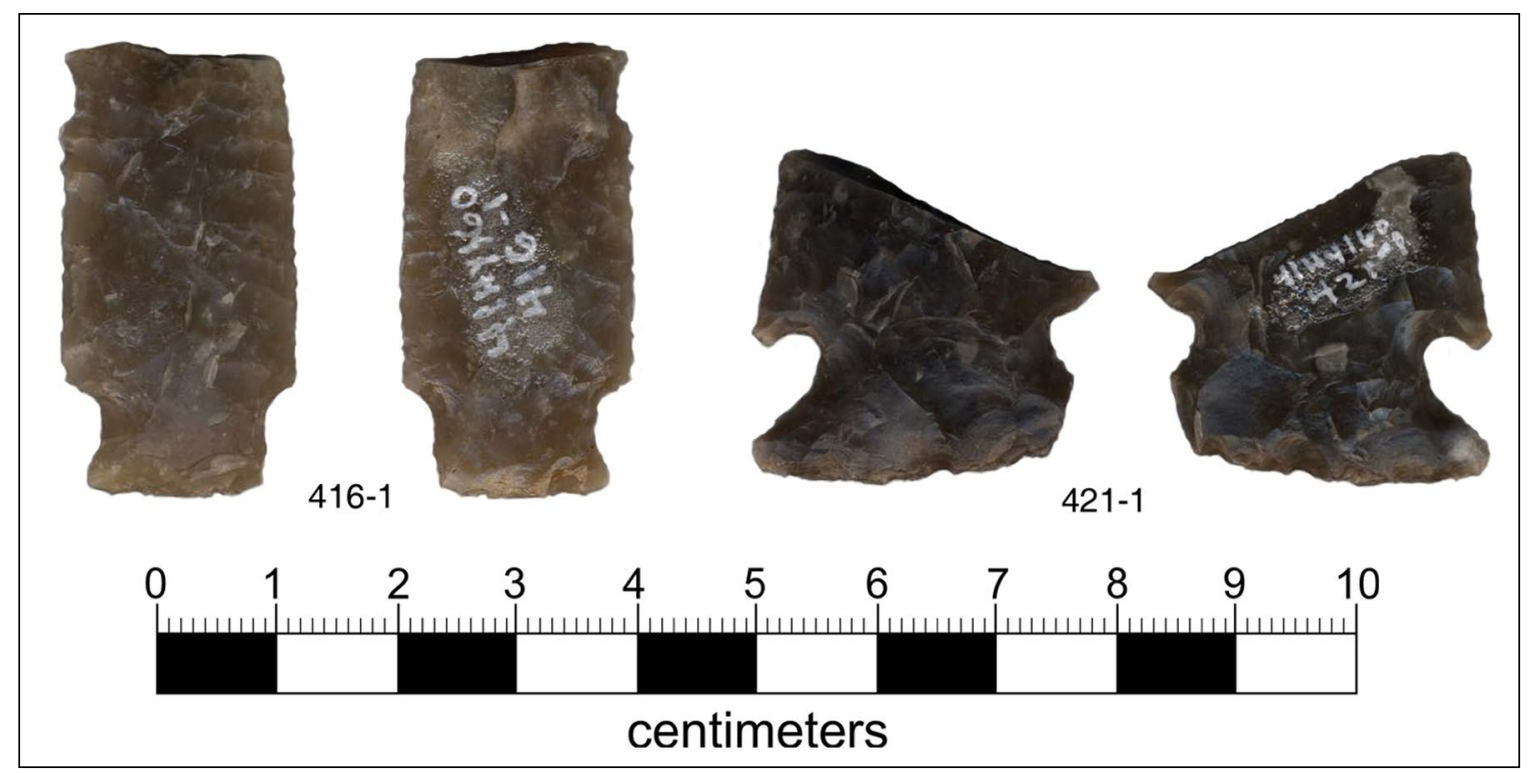

Figure 5-5. Probable Darl (left) and Ensor (right) point fragment recovered from Section III.

located in front of and between the Aquarena Center office building and the Aquarena aquarium building. XU01 was excavated to $70 \mathrm{cmbs}$, and XU02 was excavated to $40 \mathrm{cmbs}$. Both units were terminated upon uncovering two different waterlines. A water pipeline was uncovered in XU01 running diagonally through the unit from the southwest corner to the northeast corner at approximately $67 \mathrm{cmbs}$. The uncovered waterline in XU02 was encountered at approximately $40 \mathrm{cmbs}$ running parallel to the western wall through the western half of the test unit.

Numerous lithic artifacts were recovered from these units (XU01 $n=172$, XU02 $n=89$ ) and are considered to be indicative of a prehistoric presence in this area. However, due to the location of the encountered pipes within the test units, it is concluded that deposits excavated above these pipes are disturbed and do not contain intact cultural deposits. Therefore, recovered artifacts are not considered to be representative of intact, undisturbed cultural deposits. A 5-gallon bucket of soil was collected from each excavated level and subjected to water screening through $1 / 4$-inch and $1 / 8$-inch mesh. Bulk soil samples measuring
4 liters in volume were also collected from each level. These samples, however, were not processed by flotation or water screened due to the disturbed nature of their contexts.

\section{XU03}

Test unit XU03 was excavated $2 \mathrm{~m}$ south of ST138 within the boundaries of archaeological site 41HY165 (see Appendix D, Figure D-5). This site was the subject of archaeological field school investigations conducted between 1996 and 1998. Unit XU03 was excavated here during the current project as the vertical distributions of cultural deposits uncovered during the field school investigations were poorly understood. This unit was excavated in arbitrary $10-\mathrm{cm}$ levels to a depth of $150 \mathrm{cmbs}$. A burned rock layer indicative of either a hearth feature or the corner of a burned rock midden was encountered between 60 and $80 \mathrm{cmbs}$ (Figure 5-6). Two Late Archaic-style projectile points were recovered at $70 \mathrm{cmbs}$ and $70.5 \mathrm{cmbs}$ (Figure 5-7), and a large bison bone was collected from 62 to $67 \mathrm{cmbs}$. Cultural materials were recovered from all levels and excavations were halted at $150 \mathrm{cmbs}$, as continued excavations would be beyond current 


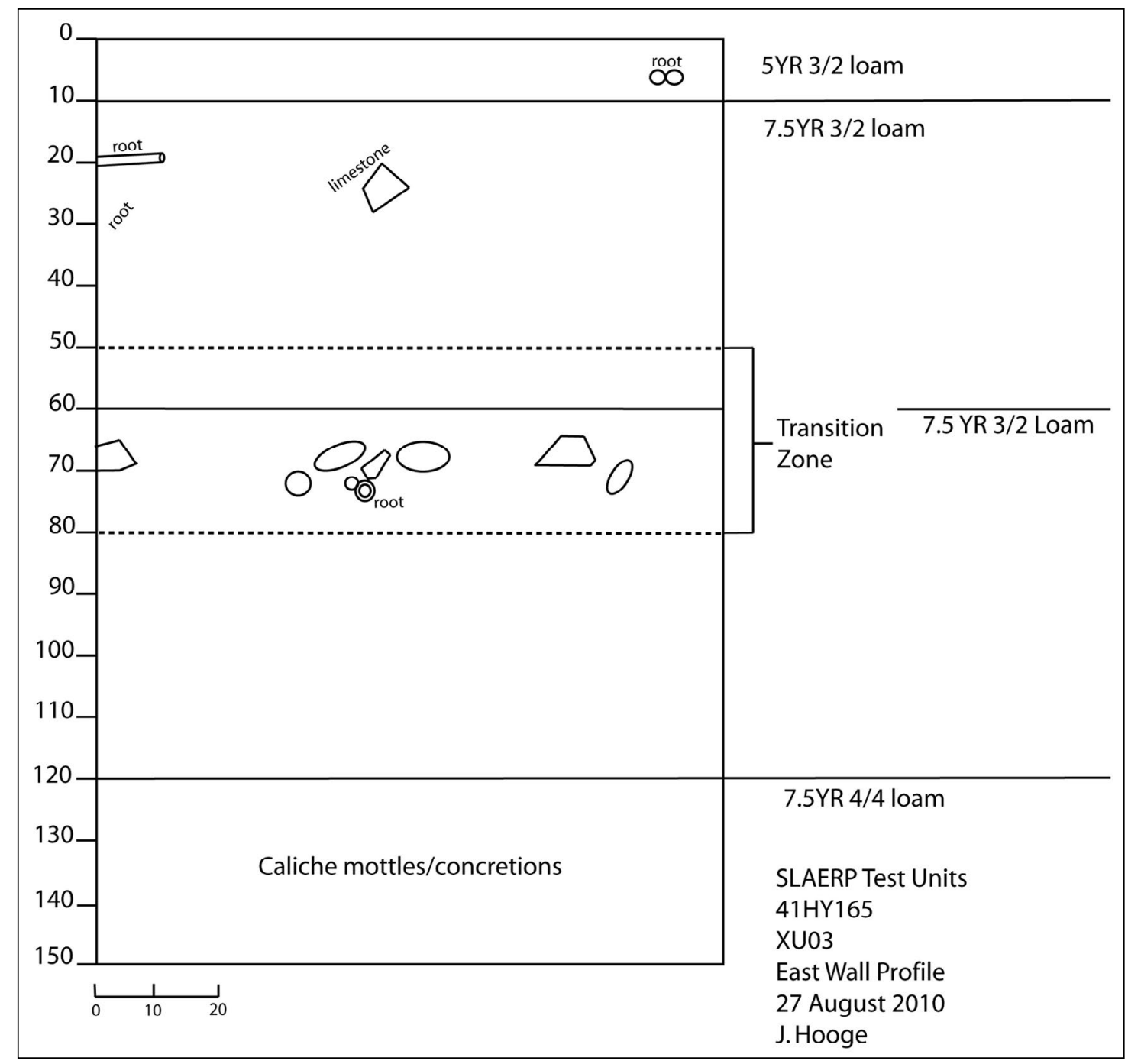

Figure 5-6. Profile of XU03 excavated within Section II.

safety standards. A 5-gallon bucket of soil was collected from each level and water screened through $1 / 4$-inch and $1 / 8$-inch mesh. In addition, 4-liter bulk soil samples were collected from each level. These samples were processed by flotation to recover small faunal remains, plant remains, and lithic debris. Among the materials recovered from this process was the microscopic tip of a projectile point, drill, or needle from Level 1 (Figure 5-8).

Historic and/or modern artifacts recovered from above $30 \mathrm{cmbs}$ suggest that the upper levels of this site maybe disturbed, even though prehistoric materials are clearly present here. Preliminary results from the excavation of this test unit indicate that intact cultural deposits are located within the boundaries of 41HY165 and extend at least from $30 \mathrm{cmbs}$ to beyond $150 \mathrm{cmbs}$.

\section{Backhoe Trench Excavations}

Four backhoe trenches were excavated in Section III in the following locations: 1) between the southern section of the parking lot and the access road 2) between the northern section of the parking lot and the access road, 3) on the median between the parking lot access road and 


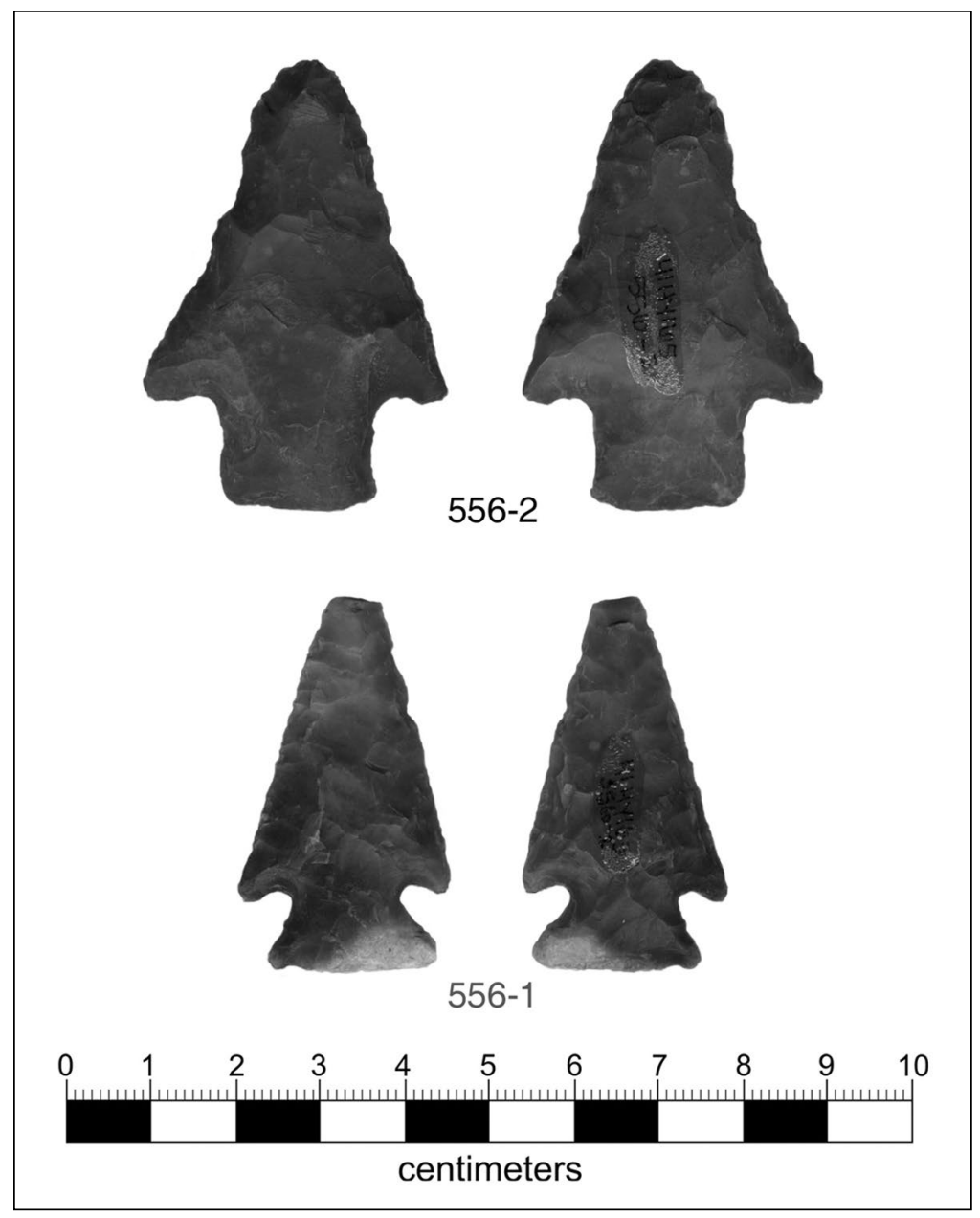

Figure 5-7. Late Archaic points recovered from XU03, within Section II.

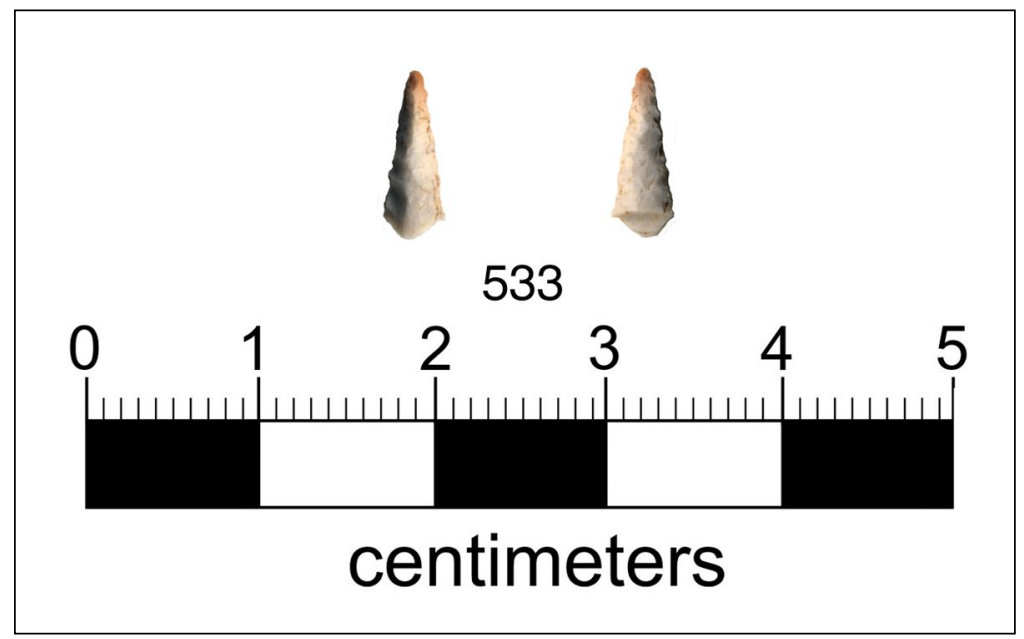

Figure 5-8. Tip of point, drill, or needle recovered from Level 1 of XU03. the golf course access road, and 4) in the northern picnic grounds (Appendix D, Figure D-6). These locations were identified during shovel test investigations as having the potential for deeply buried, stratigraphically intact deposits that would be negatively affected by the proposed undertaking. Trenches were excavated to examine the depositional history/context and to further confirm the potential of this area to contain intact archaeological deposits.

Groundwater was encountered at varying depths, and severely limited the excavation and subsequent observation of each backhoe trench. As the backhoe trench excavations targeted the narrow peninsula formed above the confluence of the San Marcos River and Sink Creek, soils encountered did not conform to either of the mapped soil series, but rather appeared as a combination of the two.

In each of the backhoe trenches, a single longitudinal exposure was chosen for profile description. Adjacent walls were also inspected for additional evidence, particularly in cases where anomalies, features, intrusions, and other important features or data were present. Zones are the basic unit of description and 
consist of distinct geological deposits, distinct soil horizons, or a combination of the former where both are present and upper and lower boundaries are distinguishable. Zone attributes including color, texture, structure, and inclusions, as well as horizon designation, lower boundaries, and depths, which were recorded and are presented in detail in Figures 5-9 and 5-10.

\section{Backhoe Trench Locations}

All four backhoe trenches were excavated on the nearly-flat terrace adjacent to the headwaters of San Marcos River just above its confluence with Sink Creek. Backhoe trenches (BHTs) 1 and 3 were oriented parallel to the potential direction of stream flow (potential is used in the case of floods and the natural behavior of the streams prior to damming), whereas BHT
2 and BHT 4 were oriented perpendicularly (see Appendix D, Figure D-6). Orientation and distribution of backhoe trench excavations were chosen to optimize artifact recovery (i.e., near shovel tests that yielded cultural material), while simultaneously exposing sediments and soils over a broad area.

BHT 1 was the southernmost excavation, and it was also the closest to the confluence of the two streams. BHT 1 was located adjacent to the southeast corner of the parking lot near Tee Box 7 of the University Golf Course. This trench measures $6 \mathrm{~m}$ long, $1 \mathrm{~m}$ wide, and just over 1 $\mathrm{m}$ deep. BHT 2 was excavated approximately $60 \mathrm{~m}$ north-northeast of BHT 1. BHT 2 was also situated adjacent to the parking lot, but was excavated perpendicular to the potential flow

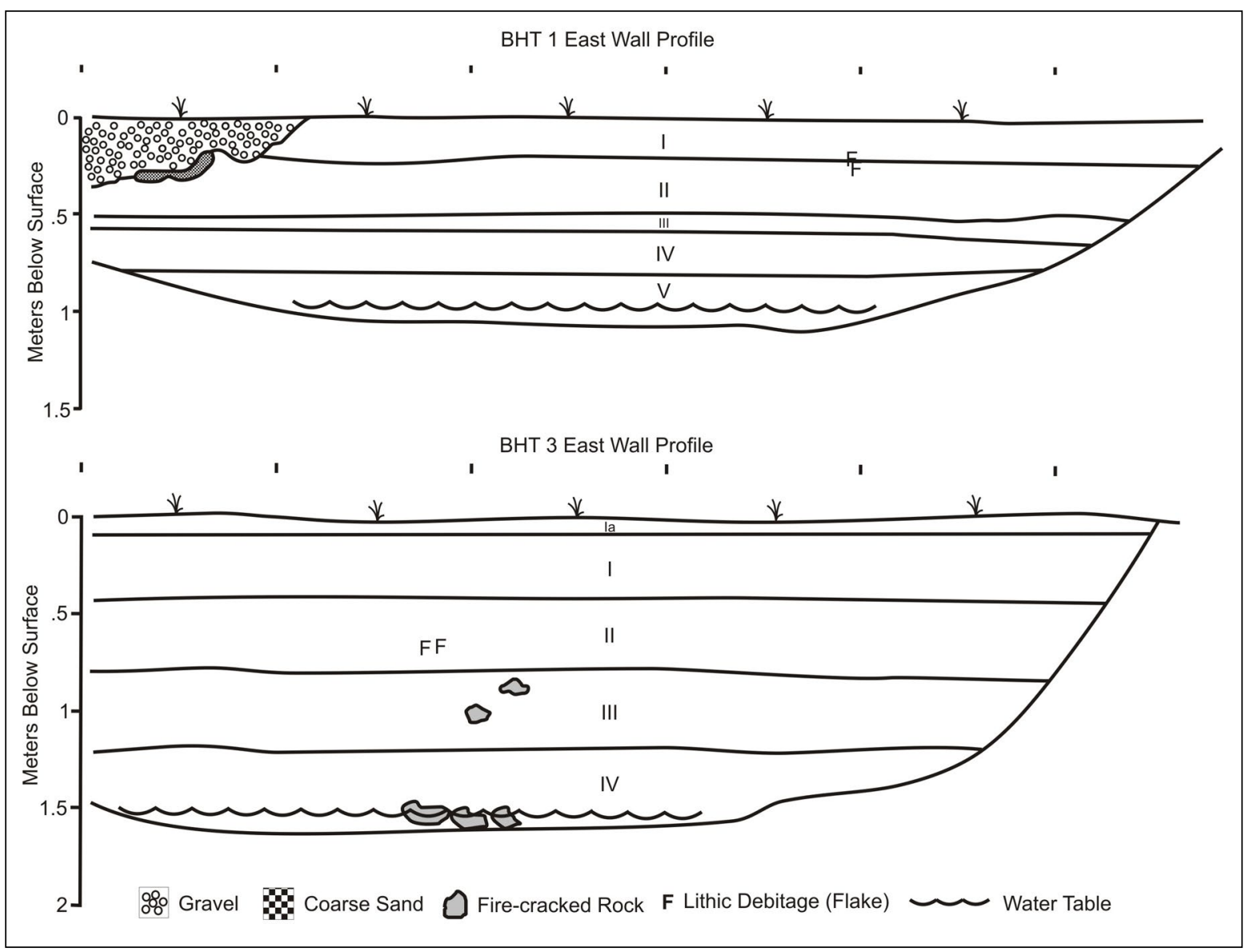

Figure 5-9. Profiles of BHT 1 and BHT 3. 


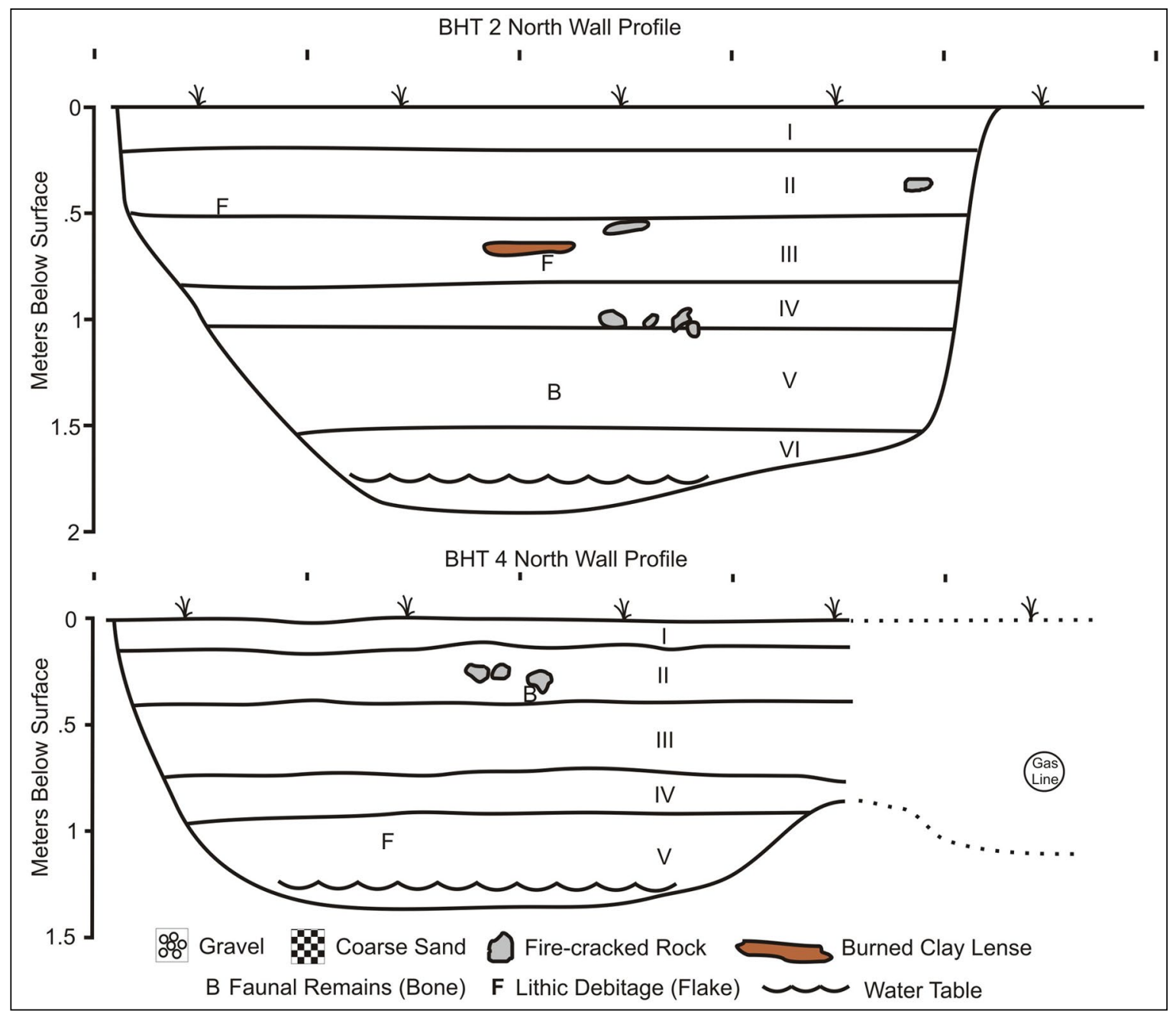

Figure 5-10. Profiles of BHT 2 and BHT 4

of the streams. BHT 2 was approximately $4 \mathrm{~m}$ long, $1 \mathrm{~m}$ wide, and $2 \mathrm{~m}$ deep. About $120 \mathrm{~m}$ north of BHT 2, BHT 3 was excavated parallel to the potential direction of stream flow and between two roads providing access to the parking lot. BHT 3 was approximately $5.5 \mathrm{~m}$ long, $1 \mathrm{~m}$ wide, and about $1.65 \mathrm{~m}$ deep. BHT 4 was excavated $30 \mathrm{~m}$ west-northwest of BHT 3 in a picnic area situated between a parking lot access road (to the east) and the top of Spring Lake (west). This trench was excavated perpendicular to the potential flow direction, and it was approximately $3.5 \mathrm{~m}$ long, 1 $\mathrm{m}$ wide, and $1.4 \mathrm{~m}$ deep.

\section{Observations: Soils and Sediments}

As much as $14 \mathrm{~cm}$ at the top of each profile exposure was disturbed as a result of routine maintenance. Evidence for this included crumby, weakly (if at all) structured organic-rich sediment and a relatively increased amount of coarse fragments. This zone is designated Ap, for plow zone (this zone is not interpreted as having been plowed). Other modern perturbations included a very gravelly zone overlying a coarse sandy zone in the northeastern corner of BHT 1. Gravels and coarse sand extended from the surface to approximately $35 \mathrm{cmbs}$, and have very abrupt boundaries. The origin and/or purpose of this intrusion are not clear. Aside from a gas 
line discovered in BHT 4, these two anomalies (i.e., Ap and gravel/coarse sand) were the only signs of modern disturbance, and otherwise sediments and soils observed in the four trenches are consistent with each other and with the soils mapped in the area.

Beneath the Ap, A horizons extended to 50 cmbs in BHTs 1 and 2 to approximately $80 \mathrm{cmbs}$ in BHTs 3 and 4. A horizons were generally weakly to moderately developed, and fine to medium subangular blocky in structure. They contained very less than five percent coarse fragments, and ranged in texture from clayey loam to silty clay, very dark gray (10YR 3/1) to very dark brown in color (10YR 2/2). Shell fragments, common roots and rootlets, and worm excrement provide evidence of bioturbation. However, no signs of severe shrink-swell dynamics were observed.

Below the A horizons and above the water table in each trench, B horizons were observed. B horizons were composed of clay loam to clay, very dark gray to very dark brown in color, and they had slightly stronger and larger subangular blocky structure than those in A horizons. In BHTs 1 and 2, the B horizon was marked by secondary calcium carbonates in the form of filaments near the top and also by mottling near the bottom of the exposures. BHTs 3 and $4 \mathrm{did}$ not exhibit secondary carbonate accumulation or mottling, but did have a marked increase in clay content. B horizons of BHTs 3 and 4 contained increased shell fragments and uncommon roots, and worm excrement was noted as deep as 90 cmbs in BHT 4. Shell, roots, and worm excrement presence are the only signs of noncultural subsoil disturbance. Sediments comprising the backhoe trench's profiles contained a very low amount of coarse fragments that were not culturally derived. Due to high water tables, excavations could not proceed beyond these depths, and no $\mathrm{C}$ horizons were observed.
Given the setting on a terrace between two streams and low amounts of gravels, it is likely that these sediments were low-energy deposits resulting from floods. Also, given the vegetation patterns adjacent to the perennial springs, it may also be the case that a portion of the sediments are formed in situ of weathering organic material.

\section{Observations: Cultural Materials}

Varying amounts of cultural materials were observed in each backhoe trench. Most artifacts were recovered without provenience. A number of artifacts were, however, observed in trench profiles; these are recorded by provenience. In the southern portion of the examined profile of BHT 1 (away from the gravel and coarse sand intrusions described above), two flakes were observed at approximately $25 \mathrm{cmbs}$. These flakes were situated at the boundary between the Ap and $\mathrm{A}$ horizons. No other artifacts were observed in situ within BHT 1.

In the northern wall of BHT 2, fire-cracked rock was observed between approximately 35 and $110 \mathrm{cmbs}$, with a distinct cluster in the center of the wall at approximately 110 cmbs. Above (67-75 cmbs) and to the left of the fire-cracked rock cluster, there was a distinct lens of burned clay. The burned clay is yellowish-red (5YR 4/6), and a sample of the material also contains small fragments of unidentifiable burned bone. A low number of flakes were also observed in proximity to the fire-cracked rock cluster and burned clay. Unidentifiable faunal remains were observed as deep as $137 \mathrm{cmbs}$, and lithic debitage was observed as shallow as $50 \mathrm{cmbs}$. No diagnostic artifacts were observed in situ or in excavated sediment, and so without radiometric dating, it is not possible to estimate cultural periods associated with these artifacts.

Similar to BHT 2, BHT 3 also contained insitu fire-cracked rock and lithic debitage. Fire- 
cracked rock was present from approximately 75 to $155 \mathrm{cmbs}$ (the maximum depth of excavation), and other cultural materials, primarily lithic debitage, were observed from about $65 \mathrm{cmbs}$ to the bottom of the trench. Artifacts appeared to be in two horizontal concentrations, one at approximately $70 \mathrm{cmbs}$ and the other near the bottom of the trench, with a relatively light scatter of artifacts between. BHT 3 also yielded a projectile point and a biface; these are without provenience (Figure 5-11).
BHT 4 contained undisturbed, intact deposits of fire-cracked rock and lithic debitage. Fire-cracked rock was observed between about 30 and $135 \mathrm{cmbs}$ (trench bottom). Unidentified faunal remains and lithic debitage were also observed in the same range of depth. These findings are consistent with the distribution of artifacts observed and recovered from previous excavations in this area. However, no temporally diagnostic artifacts were recovered from this trench.

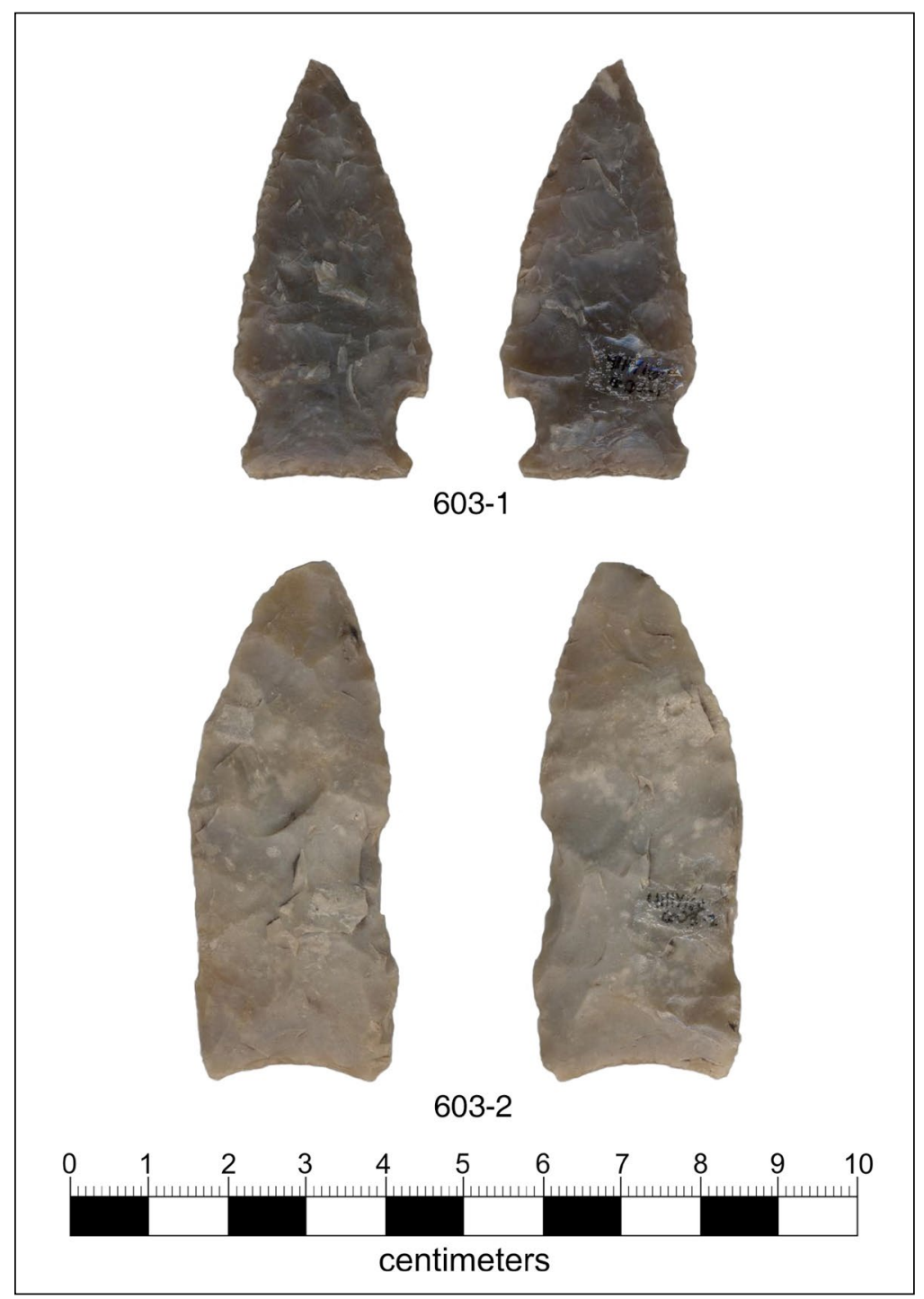

Figure 5-11. Late Archaic-period projectile point and biface recovered from BHT 3.

\section{Backhoe Trench Excavation Conclusions}

Backhoe trench excavations were conducted across Section III of the APE, and were located based on the results of shovel test investigations previously described. The objectives of this component of the project were to 1) gain an understanding of the depositional processes present in the project area in order to examine potential integrity of buried cultural deposits, and 2) identify previously unrecorded archaeological deposits. From the soils and sediments exposed in these trenches, depositional processes that shaped this part of the APE include low-energy alluviation (i.e., a distance from the main flow of flood waters) and in situ weathering of organic material. These depositional regimes have the potential to preserve intact cultural deposits. An archaeological concern with clayey soils of this nature, however, is that shrink- 
swell behavior may lead to movement of artifacts. However, proximity to a perennial water source appears to have somewhat ameliorated extreme soil moisture variability that can lead to this type of disturbance. The sediments and soils also reveal that the upper approximately $14 \mathrm{~cm}$ have been recently disturbed and therefore may lack integrity in certain localities. Below this initial zone (Ap), perturbations are localized (i.e., occur with utility lines and other infrastructure), and sediments and soils appear to be mostly intact with varying, albeit low, amounts of bioturbation caused by roots and worm activity. Cultural materials were observed in and recovered from all backhoe trenches, and intact cultural deposits were identified in BHT 2, 3, and 4. However, lacking provenienced diagnostic artifacts, these cultural deposits are not anchored in time.

\section{Auger Investigations}

An auger pit was excavated in the location of a proposed lift station to be associated with new infrastructure following the removal of existing buildings (see Appendix D, Figure D-7). The pit measured $38.1 \mathrm{~cm}$ in diameter and $431.8 \mathrm{~cm}$ deep, and was excavated at the western edge of the parking lot in the center of the western end of the peninsula. Insofar as possible, sediments were excavated in 61-cm (2-ft) levels. Approximately 50 percent of all of the excavated sediments from each 2-ft level were screened and described.

From the surface to approximately $30 \mathrm{cmbs}$, sediments appeared relatively modern, and included a mix of yellowish-brown very gravelly clay fill and asphalt (Figure 5-12). Beneath this modern cap, black silty clay extended to 63.5 cmbs. Deposits at approximately 63.5-144.78 cmbs were composed of very dark gray silty clay with 10 percent coarse fragments. Nearing $144.78 \mathrm{cmbs}$, the sediment became increasingly moist to the point of saturation. Beneath the water table, sediment was very dark gray sandy clay and contained approximately 15 percent coarse fragments to a depth of $177.8 \mathrm{cmbs}$. Between 177.8 and $218.44 \mathrm{cmbs}$ sediment was similar to that in the level above; however, scattered subangular pebbles and cobbles (5-8 $\mathrm{cm}$ in diameter) were encountered. To a depth of $325.12 \mathrm{cmbs}$, sediment encountered was very dark grayish-brown silty clay with 15 percent coarse fragments and 10-20 percent distinct dark yellowish-brown mottles. From $325.12 \mathrm{cmbs}$ to depth $(431.8 \mathrm{cmbs})$, there was strong brown clay with 25 percent distinct dark yellowish-brown and dark grayish-brown mottles and approximately 10 percent coarse fragments. Overall, these sediments were similar to others encountered in the vicinity of the springs, and aside from the uppermost $30 \mathrm{~cm}$, appear intact.

The auger unit is easily the deepest exposure achieved during all investigations conducted on the peninsula during this project. As such, finding comparable soils data from other exposures is difficult or impossible. Still, different lines of contextual data are available from nearby. Backhoe trenches east of this auger test terminated at the water table, approximately $1.5 \mathrm{~m}$ below the surface, and did not reach deeper sediments excavated by auger. Backhoe trenches did, however, contain cultural material in intact contexts. Sediment cores removed from off shore (see below) revealed deposits similar to, if not the same as, the bottom zone (325.12-431.8 cmbs) seen in the auger. In the subaqueous cores, this stratum is topped by disconformities, with millennia of "missing" or eroded sediment. Given the above factors, the presence of cultural material nearby, and the depth of impact for the proposed construction at this location, there is potential to encounter a long record of artifacts. However, no artifacts were recovered or observed in the auger, and it is not presently confirmed that cultural deposits are present here. 


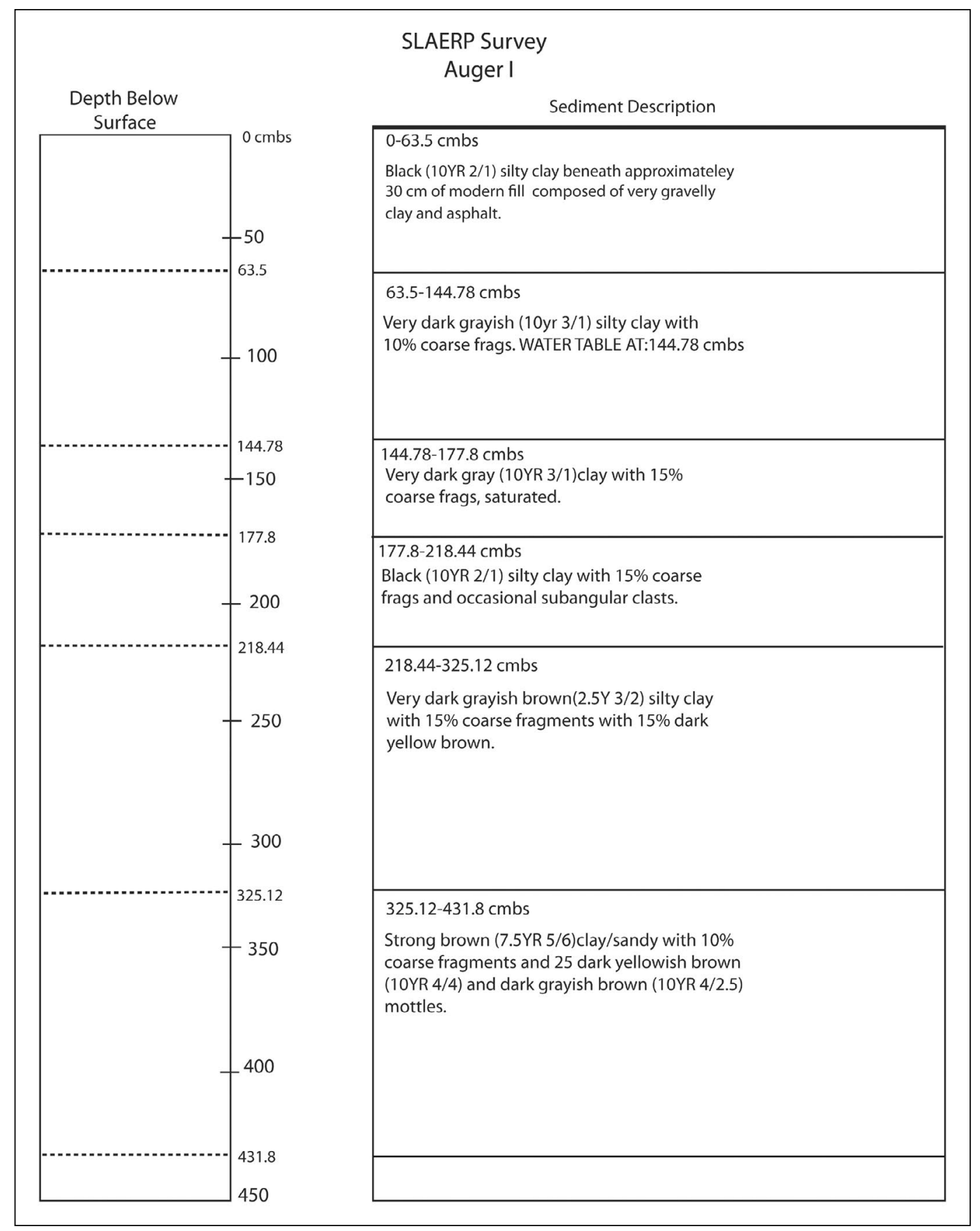

Figure 5-12. Auger unit technical description.

\section{Results of Underwater Investigations}

CAS also conducted underwater investigations in areas that will potentially be impacted by the proposed undertaking. These areas were detailed in Chapter 4, and include submerged land formations in front of and behind the Submarine Theatre (sub), and submerged land formations located at the far western end of the peninsula adjacent to the Landing. Investigations consisted of visual inspections, extraction and description of several sediment cores, submission 
of selected sediment and organic samples for dating, and excavation of a test unit.

\section{Reconnaissance - Submarine Theatre}

Prior to coring and excavations, the entire circumference of the sub was examined. Throughout the process of designing project specifications, it was uncertain whether the bottom of the sub was in physical contact with the lake bed and whether there was the potential for impacts to arise from the removal of the sub. Examination clearly showed that the bottom of the sub is in fact in direct contact with the lake bed in a number of places around its perimeter, though it is resting a slight distance above the lake bed in a few locations (Figure 5-13). Generally, the

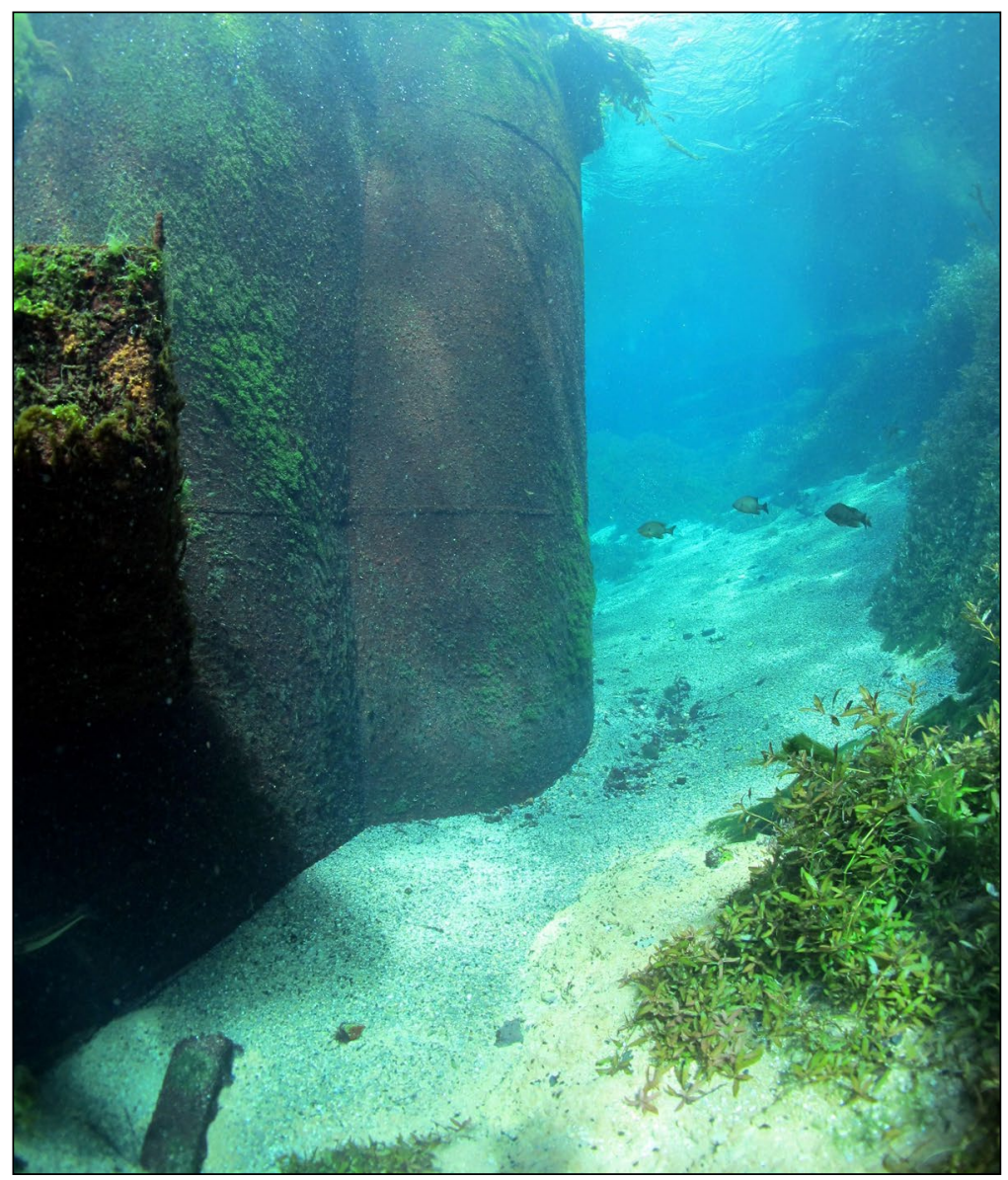

Figure 5-13. Rear of sub showing direct continuous contact between the lake bed and the base of the submerged structure. entire rear or back side of the sub contacts lake bed sediments, while intermittent places along the sub's front are also in contact with sediments (Figure 5-14).

During the visual assessment, a deposit of pea gravel was identified across the entire area in front of the sub. This material was deposited in modern times while Aquarena Springs was in use as an amusement park in an effort to prevent lake bed sediments from being stirred up during underwater performances. Very little to no pea gravel was noted across the rear of the sub. Depths of this layer of gravel vary at present from only a couple of inches to as much as $2 \mathrm{ft}$. Where it is present, this deposit of pea gravel has the ability to effectively cap underlying intact deposits, and may offer an important degree of protection from potential impacts through the course of the removal of the sub.

This visual reconnaissance survey clearly determined that the sub is in contact with the lake bottom. CAS concludes that the removal of this structure has the potential to impact underlying sediments. However, this reconnaissance did not establish whether sediments are intact, or whether they contain cultural materials. To address these issues, sediment cores were extracted and a test unit was excavated in front of the sub. These are discussed below.

\section{Reconnaissance - Upper Spring Lake}

A visual reconnaissance survey was also conducted of 


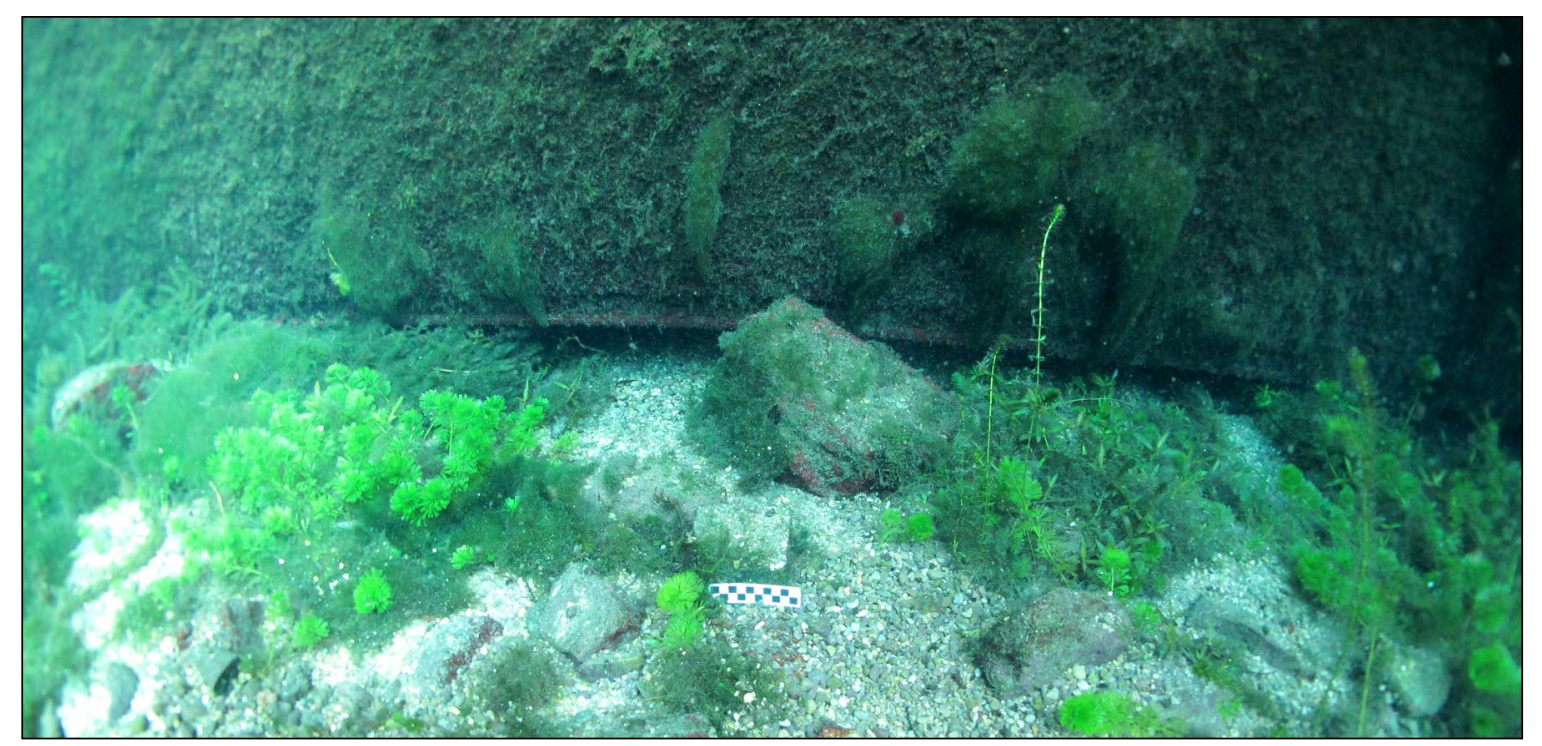

Figure 5-14. Part of the front of the sub where contact with lake bed sediments is intermittent.

upper Spring Lake through a series of dives (Figure 5-15). While the heavy vegetation in the lake precluded an assessment of all lake bed sediments, areas surrounding the numerous springs remain relatively free of vegetation and can be visually inspected. Archaeologists observed vast quantities of lithic debitage and chipping debris in these areas, and documented preforms, blade cores, scrapers, and intact bifaces and projectile points dating from the Middle and Late Archaic to Late Prehistoric period, in the limestone sands (Figures 5-16, 5-17, 5-18). These artifacts were generally distributed across the entire

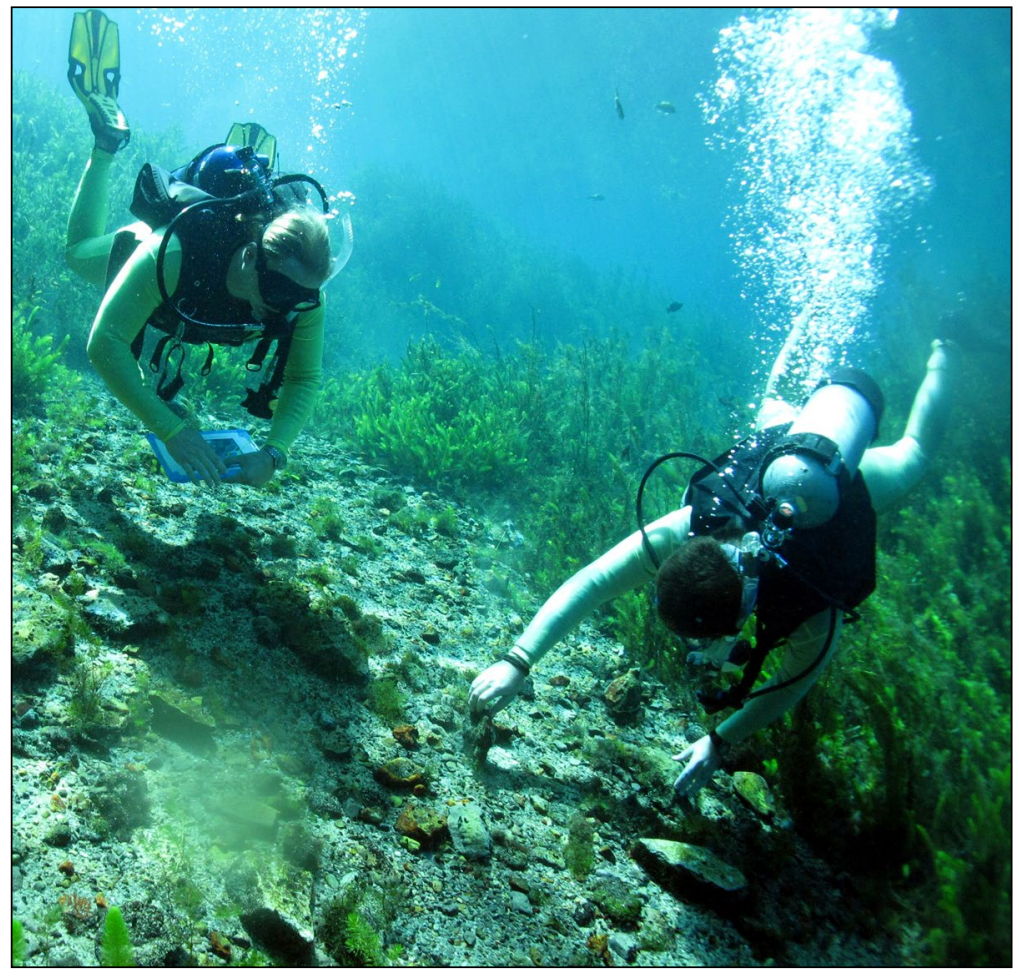

Figure 5-15. Underwater archaeologists conducting underwater reconnaissance survey. area of upper Spring Lake, but several locations of dense concentrations were noted along the lake bottom and eroding out of bank walls (Figure 5-19). These deposits are believed to be an extension of $41 \mathrm{HY} 160$.

\section{Test Unit}

A $50 \times 50-\mathrm{cm}$ test unit was excavated at Site No. 1 in front of the sub (see Appendix D, Figure D-8). The unit was excavated to 


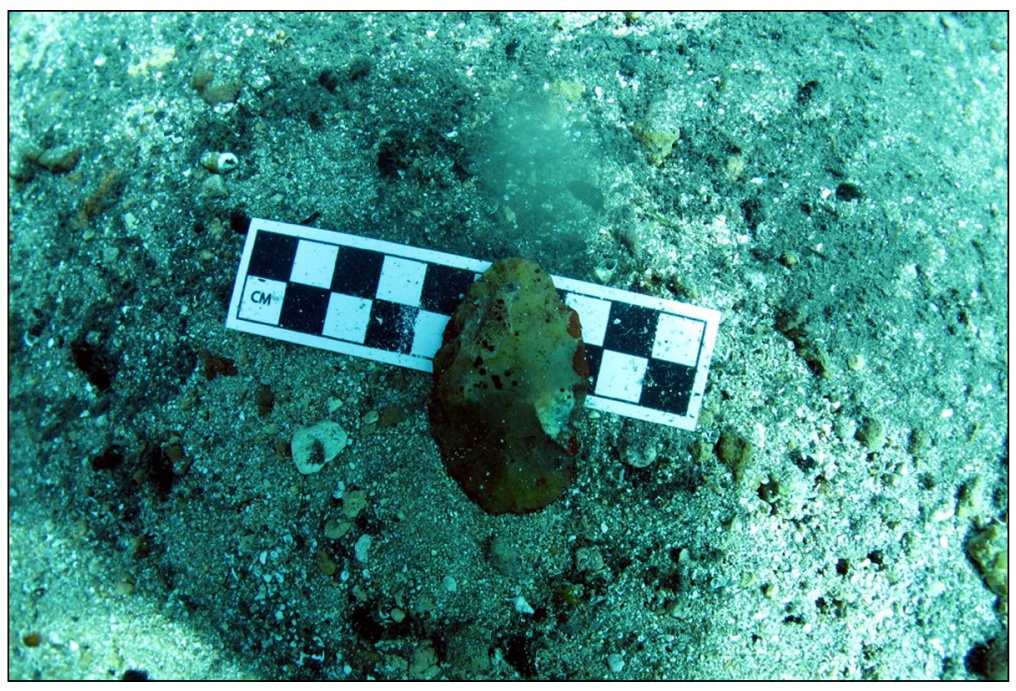

Figure 5-16. Chipped stone biface on bottom of Spring Lake.

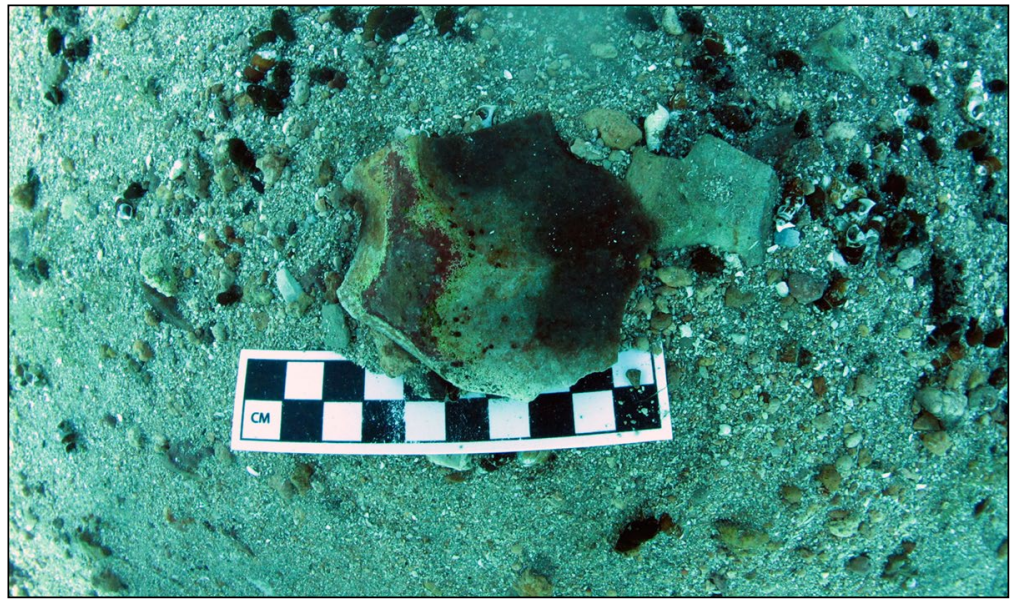

Figure 5-17. Possible scraper found on lake bed. approximately $1.4 \mathrm{~m}$ below the lake bottom (Figure 5-20) in order to visually assess the stratigraphy of sediments underneath the sub. The unit revealed three main depositional strata. The bottommost of these three strata was composed of poorly sorted, clast-supported, subround cobbles as large as $20 \mathrm{~cm}$ in diameter, encased in reddish sandy matrix. The middle unit is composed of grayish clay containing organic material and poorly sorted, matrixsupported, subround cobbles, ranging from 1 millimeter $(\mathrm{mm})$ to $10 \mathrm{~cm}$ in diameter. Organic matter in the middle stratum included pieces of wellpreserved wood, a fragment of which was radiocarbon dated to $13,320-13,190$ cal BP $(2 \sigma)$. Upper and lower boundaries of the approximately $40-\mathrm{cm}-$ thick middle stratum were abrupt. Overlying the middle

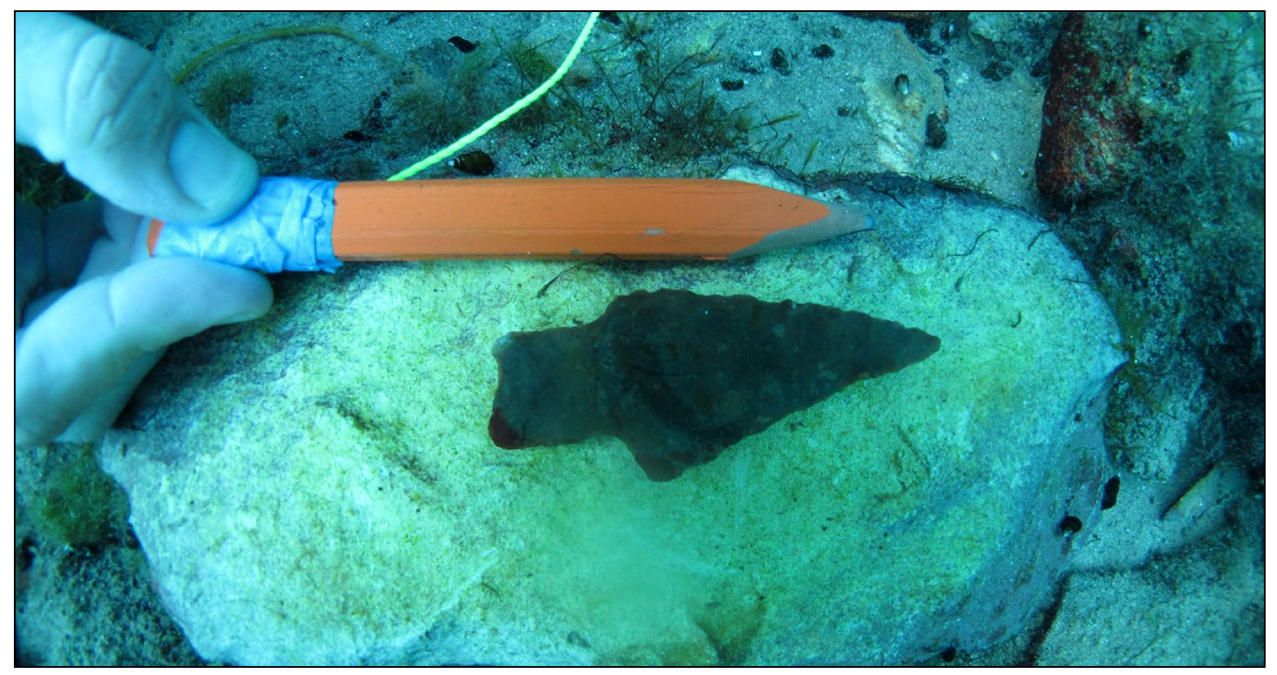

Figure 5-18. Probable Middle Archaic point. 


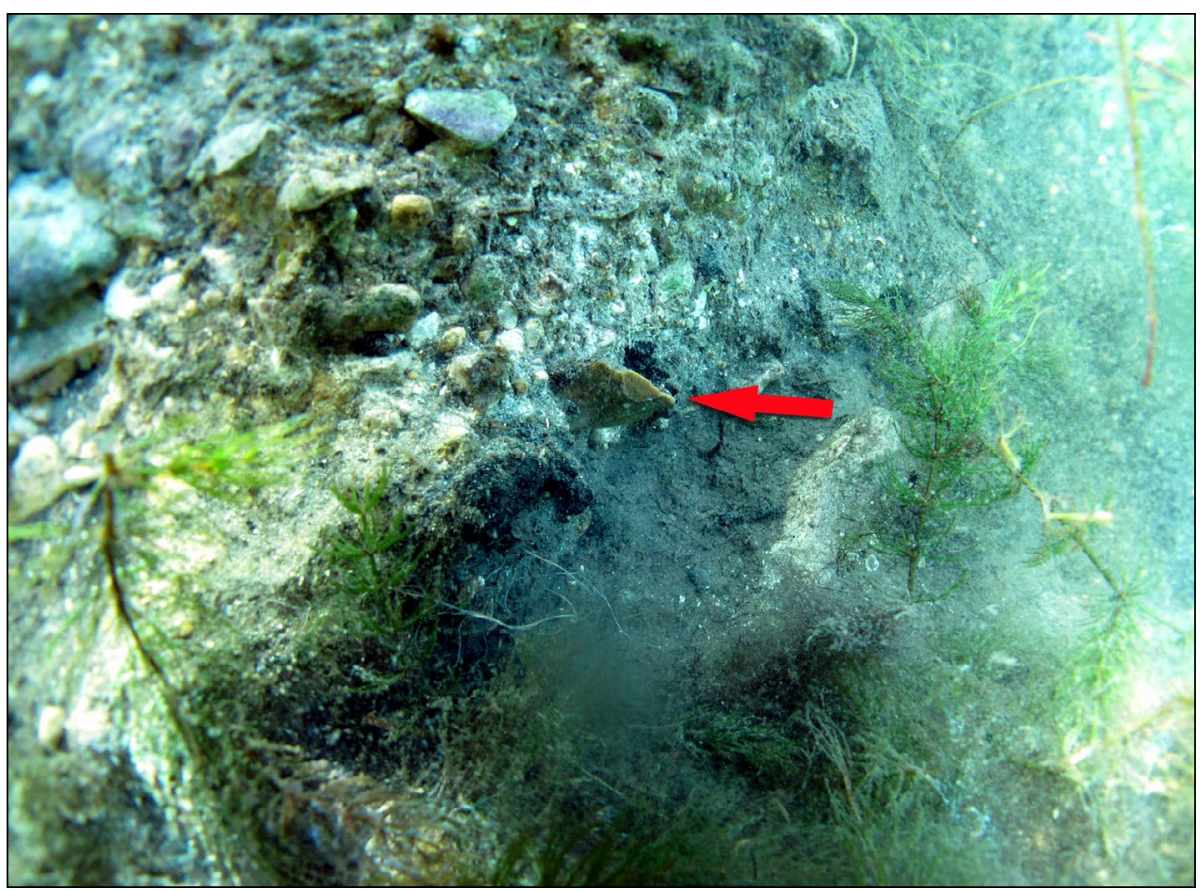

Figure 5-19. Cultural material eroding from bank.

deposit was another depositional stratum containing an increased amount of gravels. Unlike the bottom stratum, this upper stratum contained bedded, moderately sorted, matrixto clast-supported, subround gravels encased in reddish to yellowish clays.

Together, these three depositional strata represent disparate alluvial facies, which are believed to represent ancient features (e.g., gravel bar, floodplain/marsh) closely associated with the channel of the San Marcos River. These features may be attributable to fluctuation in discharge from the adjacent springs, and/or different periods/amounts of influence from Sink Creek (and/or its watershed). Sink Creek currently merges with Spring Lake and the San Marcos River about $150 \mathrm{~m}$ downstream from the project area. In any case, the upper and bottom deposits are stream-derived gravels, whereas the organicrich middle stratum is a floodplain/marsh deposit.

\section{Core Extractions}

To further explore the nature of the sediments beneath the sub, several sediment cores were extracted in front of and adjacent to the sub, and also near the Landing where a boat ramp is to be constructed (Figure 5-21). Before this work started, deposits of pea gravels were removed from each location (if present) so that samples could be extracted as closely as possible from the sediments that remained below the gravel layer(s).

Core samples were taken from locations along the front of the sub designated Site 2 (2 cores), Site 3 (3 cores), Site 4 (1 core), and Site 6 (1 core) (Table 5-1, see Appendix D, Figure D-8). The core from Site 6 was extracted with great difficulty, so no additional core was taken from Site 5 (adjacent to and within the same sediment type as Site 6), as had been initially planned. Additionally, Site 1 is the location of a test unit extending $\sim 145 \mathrm{~cm}$ beneath the lake bed (see Figure 5-20). 


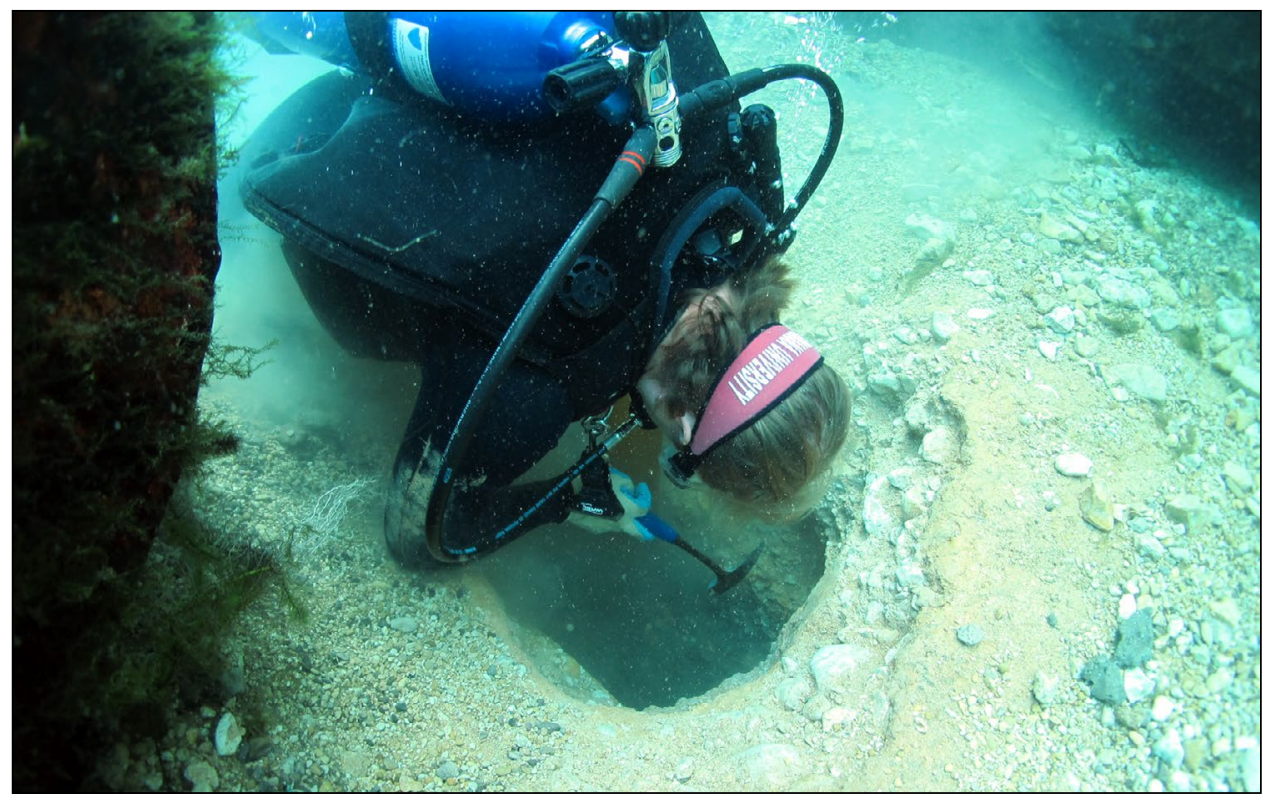

Figure 5-20. Test unit in excavation in front of sub.

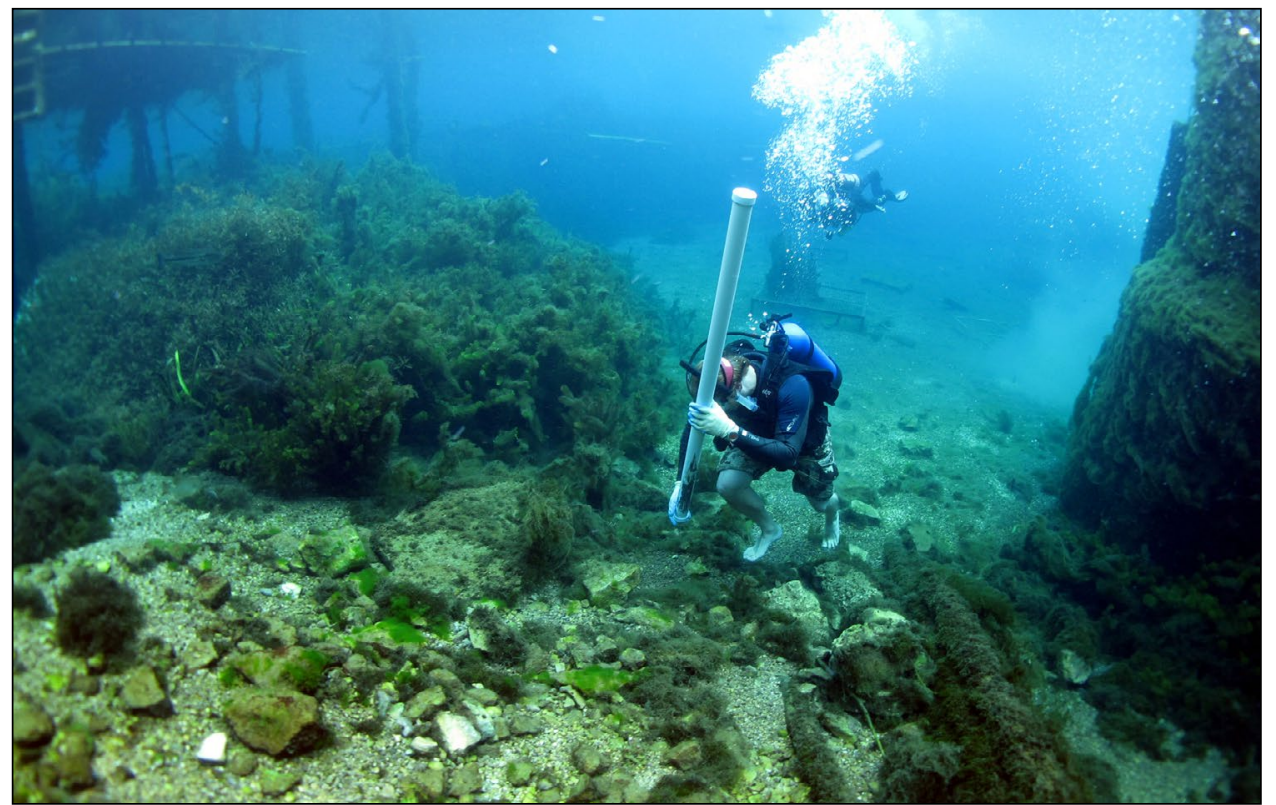

Figure 5-21. Archaeologist removing one of the sediment cores from near the sub.

The extracted cores revealed intact, bedded strata in the sediments underlying the sub. Descriptions of these strata are presented in Appendix B, Table B-1. Five sediment and organic samples from these cores were submitted to Beta Analytic for radiocarbon dating and are presented Appendix B, Table B-2.
Sediments recovered from the first set of cores contain differing characteristics than those observed in the test unit. A surprising aspect of these sediments is that they did not contain the same gravelly strata noted in the unit. This evidence suggests that the upper gravelly stratum exposed in the pit represents a gravel bar, as 
Table 5-1. Proveniences of

Extracted Cores.

\begin{tabular}{cc}
\hline Site Number & $\begin{array}{c}\text { Number of } \\
\text { Cores }\end{array}$ \\
\hline 1 & 0 \\
2 & 2 \\
3 & 3 \\
4 & 1 \\
5 & 0 \\
6 & 1 \\
7 & 1 \\
8 & 1 \\
9 & 1 \\
10 & 1 \\
11 & 1 \\
12 & 1 \\
\hline
\end{tabular}

indicated earlier. Cores extracted from Sites 2 and 3 (Figure 5-22), located on either side of the excavated pit and at elevations corresponding with the upper gravelly unit, contained similar (to each other) fining-upwards sequences of dark sediments with basal small $(<2 \mathrm{~cm}$ diameter), moderate- to well-sorted, clast-supported, subround gravels. These gravels are noted in Figure 5-22 as "Gravelly marker stratum." The fining-upwards sequence present in the three cores is currently interpreted as a floodplain/ marshy environment. Bulk sediment samples, one from below the gravelly zone in a core from Site 3 and one from the top of the finingupwards sequence in a core from Site 2, frame the deposit between 2790-2730 BP and 1510$1460 \mathrm{cal}$ BP $(2 \sigma)$. It is possible that the younger age, derived from the top of the fining sequence, could be older. A concern with radiocarbon dating sediments in lacustrine environments involves the introduction of older material (and older carbon) to the sediment sampled (Goudie et al. 1981). CAS acknowledges that this margin of error exists; however, as these sediments appear to represent a formerly terrestrial environment, as the lake has been in existence for a relatively short amount of time (ca. 150 years, see Nickels and Bousman 2010), and as pea-gravel has covered these sediments for at least half of the time they were submerged, they are considered to be intact and relatively free of disturbance.

On the far eastern side of the sub, Core 7 from Site 6 contained different sediments. Here, two distinctly different strata are marked by an abrupt interface; the lower was yellowish clayey matrix with strong ped development and nodular calcium carbonate, and the upper is darker in color and contains a small amount of matrixsupported, subround gravel. Development of ped structure and secondary carbonates can be a function of time (Birkeland 1999; Schaetzl and Anderson 2005), and though currently submerged, these sediments and soils were clearly terrestrial in their past. Two samples were extracted from this core: one from the top of the lower stratum, and the other from the top of the upper stratum. An age of 19,300-19,020 cal BP $(2 \sigma)$ marks a minimum age of deposition and soil formation of the lower stratum, and it also serves as a maximum age of the upper stratum. The sample from the top of the upper stratum provides a minimum age of 7680-7580 cal BP $(2 \sigma)$. The age of these sediments, in addition to their relative elevations, indicates that they were once on a terrace above the river channel.

The investigation of sediments immediately in front of the sub show that this location, close to a number of different alluvial environments (e.g., terrace, marsh, channel), was once more dynamic than today and contains complex stratigraphy. While sediments and soils encountered in front of (spring-side) and to the east of the sub date to periods that are relevant to archaeology in Central Texas $(<12,000$ years BP), these sediments represent environments (e.g., marsh and river channel) that are not conductive to preserving intact archaeological deposits. 


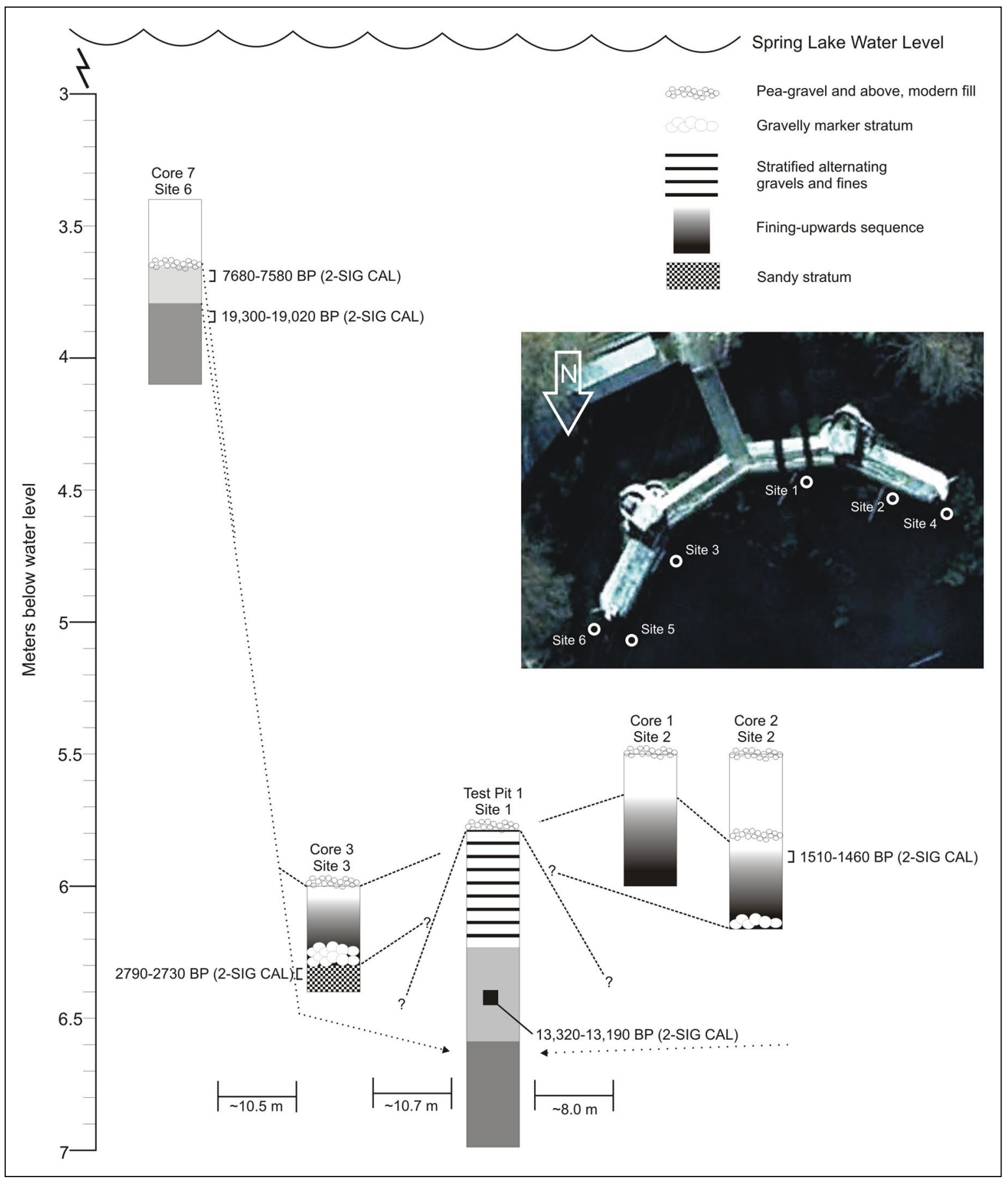

Figure 5-22. Stratigraphic reconstruction based on results from coring, excavation, and radiocarbon analysis adjacent to the spring-side portion of sub.

A second set of four sediment cores were extracted from Sites 7, 8, 9, and 10 (west to east) located behind the sub and adjacent to Spring Lake's southern bank (see Appendix D, Figure D-8). These cores all contain at least one stratum similar to that of Site 6 (from initial coring investigations), which yielded radiocarbon dates of $7630 \pm 50$ and 19,260 \pm 140 cal BP $(2 \sigma)$. This common stratum, compared to the overlying sediment, is considerably lighter or yellowish 
in color, has blocky structure, contains clay coats, and also contains calcium carbonate nodules, irrefutable evidence of having once been terrestrial. Site 7's core contained only this stratum, whereas cores from Sites 8, 9, and 10 contained approximately $11-25 \mathrm{~cm}$ of this older deposit overlain by relatively dark and organicrich sediment. The overlying sediment in each of these cores could be divided into two strata: at the top of each core was a spongy layer with tremendous amounts of well-preserved organic material (15-35 cm thick), and below, lying directly atop the older deposit, was clayey sediment with varying amounts of organic material, shells, and coarse fragments $(10-25 \mathrm{~cm}$ thick). Two radiocarbon samples were collected from this suite of cores; one from the yellowish stratum at Site 9, and the other from the directly overlying sediment at Site 10. The yellowish sediment yielded a date of 10,370 \pm 130 cal BP $(2 \sigma)$, and the sediment above yielded a date of $1080 \pm 100$ cal BP $(2 \sigma)$. These dates corroborate the younger, mid-Holocene, age yielded from Site 6 , and suggest that the strata directly overlying the yellowish sediment are also prehistoric, and thus, potentially terrestrial in origin.

Two additional cores were extracted from Sites 11 and 12 located at the west end of the peninsula to determine the likelihood that the proposed construction of the boat ramp would disturb deposits with the potential to contain cultural remains. Cores extracted from this location also contain the contact between yellowish and dark, organic-rich sediments. These two cores are similar to the sediments near the sub in that they contain the yellowish sediment at the bottom and spongy sediment at the top. They differ, however, in the middle strata. Dark, organic-rich sediment just above the contact zone is clearly bedded. Two radiocarbon samples were taken from Site 11's core, one from just below the contact, and one from just above. These samples yielded dates of $8235 \pm 25 \mathrm{cal}$ BP $(2 \sigma)$ and $1235 \pm 65$ cal BP $(2 \sigma)$, respectively. Both dates are prehistoric and suggest that these sediments were formerly terrestrial. Bedding of the dark, organic-rich sediment above the contact zone, however, indicates that this location was frequently flooded. As the San Marcos River's discharge is regulated by the springs at the headwaters of the river (and bedding is not clearly seen in contemporary sediment from near the theater), it seems that the bedding of sediments is a function of Sink Creek floods.

Sediments encountered in this second suite of cores, extracted from behind the sub and from the west end of the peninsula near the Landing, are relevant to culturally significant periods and represents formerly terrestrial environments. Though no artifacts were encountered in any of the cores, their proximity to significant sites suggests that the paucity of artifacts should not be taken as an indication that no archaeological materials are here. 


\section{Chapter 6}

\section{Summary, Discussion, AND RECOMMENDATIONS}

An archaeological cultural resources survey for the SLAERP was conducted in response to the MOA signed by the USACE, THC, and TxState. This MOA calls for an archaeological assessment of the APE to determine the extent of intact cultural deposits within the project area. A testing program was developed and implemented by CAS that included both terrestrial and underwater investigations. Terrestrial investigations consisted of pedestrian survey, shovel test excavation, test unit excavation, auger pit excavation, and backhoe trench excavation. Underwater investigations included reconnaissance survey, test unit excavation, and extraction of sediment cores. Four archaeological sites, 41HY160, 41HY165, 41HY161, 41HY147, have been previously recorded within the project area; however, none of these sites were completely surveyed when they were recorded, and as a result the boundaries of all sites within the APE are poorly and imprecisely known. Therefore, it was recognized that there is a high probability that ground-disturbing activities will encounter additional, yet-unknown cultural resources at or just below the surface that may appear to be outside the previously charted boundaries of any particular site.

As the previously recorded sites located within the APE have never been completely surveyed or delineated prior to this undertaking, efforts focused on identifying the distribution of remains across the entire APE with the understanding that newly encountered deposits are associated with one of the four previously recorded SALs (41HY160, 41HY161, 41HY165, 41HY147) and do not represent new sites. Results of the archaeological survey, therefore, were used to define locations labeled as Archaeologically Sensitive Areas within existing SALs. ASAs are areas that (1) represent intact and near-surface archaeological deposits that are associated with one of the SALs, (2) have the very high likelihood of containing significant deposits, and (3) will be adversely affected by the proposed undertaking. As a result of this work, the site boundaries for 41HY160 and 41HY165 were modified to include archaeological materials encountered outside of and adjacent to the previous site boundaries. These new boundaries indicate the nearly continuous presence of prehistoric remains across the APE, confirming that these sites actually represent a single extensive complex of archaeological deposits associated with the freshwater springs that presently form Spring Lake. As proposed, the undertaking will not affect $41 \mathrm{HY} 147$ or 41HY161.

Based on pending impacts indicated in the 65 percent project design documents together with the results of the survey, six areas identified as "Archaeologically Sensitive" contain or possess a high probability to contain cultural deposits that would be negatively impacted by the proposed undertaking (see Appendix E, Figure E-3). Each of these archaeologically sensitive areas is associated with either $41 \mathrm{HY} 160$ or $41 \mathrm{HY} 165$, although, given the continuous nature of deposits 
in the APE, CAS concludes that distinctions between these trinomials are less meaningful than previously believed. The results of the survey and subsurface testing that are presented in this report will inform the HPTP. That document (forthcoming) will present recommendations for mitigating documented resources that will be affected by the proposed undertaking. The HPTP will be submitted for review as a separate report.

\section{Summary}

\section{$41 H Y 161$}

SAL 41HY161 lies just outside of the SLAERP survey area, to the southwest of Section I (see Appendix E, Figure E-2). No cultural deposits were noted in the portion of Section I adjacent to site 41HY161, and therefore the boundary of this site was not modified. As the site lies outside of the APE, it will not be impacted by the proposed undertaking. No recommendations are warranted.

\section{$41 H Y 147$}

41HY147, also a SAL, is located along a large submerged terrace adjacent to the western bank and within Spring Lake and survey Section I. This location was also determined to be outside of any pending impacts and therefore not subject to survey investigations. As the location of site appears to be imprecisely mapped on the Texas Archeological Sites Atlas, its location was remapped using the sketch map submitted with the original archaeological site form and visual assessments (see Appendix E, Figure E-4). According to the 65 percent design plans for the SLAERP, site $41 \mathrm{HY} 147$ will not be impacted. Therefore, no recommendations for this site are warranted at this time.

\section{$41 H Y 160$}

SAL 41HY160 occupies the peninsula between Spring Lake and Sink Creek, upon which Aquarena Center and a portion of the TxState Golf Course is located. According to the Texas Archeological Site Atlas, no site boundaries existed for this site prior to the current survey effort; however, all previous archaeological investigations conducted on the peninsula attributed encountered archaeological deposits to 41HY160. As a result of the archaeological survey, CAS has redrawn the boundaries of site $41 \mathrm{HY} 160$ to include archaeological deposits encountered during both terrestrial and underwater investigations on and adjacent to the peninsula, as well as archaeological deposits noted during previous investigations (see Appendix E, Figure E-4). Large quantities of lithic debitage noted during the underwater reconnaissance survey of upper Spring Lake are now attributed to SAL 41HY160. Much of this debris is present on the lake bed where vegetation permits good visibility, while abundant materials were also noted eroding from the peninsula's banks. Four ASAs (ASA 1, ASA 2, ASA 5, and ASA 6) were identified within SAL $41 \mathrm{HY} 160$ during investigations (see discussion on ASAs below; Table 6-1). CAS recommends the development of mitigative measures to offset the potential loss of information from these locations within SAL 41HY160 that may result from the proposed undertaking.

Table 6-1. ASAs and Associated

SALs.

\begin{tabular}{cc}
\hline ASA & SAL \\
\hline ASA 1 & 41 HY160 \\
ASA 2 & 41 HY160 \\
ASA 3 & 41 HY165 \\
ASA 4 & 41 HY165 \\
ASA 5 & 41 HY160 \\
ASA 6 & 41 HY160 \\
\hline
\end{tabular}


$41 H Y 165$

Located at the confluence of Sink Creek and Spring Lake, SAL 41HY165 sits on a small peninsula that extends out into the eastern half of the lake and follows along the lake margins to the southwest and along Sink Creek to the northeast (see Appendix E, Figure E-4). The site boundaries were also redrawn to include deposits encountered during the current survey. Two ASAs (ASA 3 and ASA 4) were identified and attributed to SAL 41HY165 during survey investigations (see Table 6-1 and discussion below). CAS also recommends the development of mitigative measures to offset the potential loss of important archaeological information that may result from the proposed undertaking.

\section{Discussion}

\section{Archaeologically Sensitive Areas}

The current boundaries of SALs 41HY160 and 41HY165 were redrawn as a result of survey investigations. These new boundaries indicate the nearly continuous presence of prehistoric remains across the APE, confirming that these sites actually represent a single extensive complex of archaeological deposits. Consequently, investigative efforts focused on identifying the distribution of remains across the entire APE to determine the extent of intact cultural deposits within the project area, with the understanding that newly encountered deposits are associated with one of the previously recorded SALs. These deposits were designated as Archaeologically Sensitive Areas. Six ASAs were identified during survey investigations.

Two areas containing dense concentrations of intact cultural deposits, ASAs 1 and 2, were encountered during shovel test excavations within Section III. These intact prehistoric lithic deposits cluster around the Aquarena Aquarium
Building and the grassy area adjacent to the parking lots within the northeastern portion of Section III. These intact deposits were attributed to SAL 41HY160 (see Table 6-1, Appendix E, Figure E-3).

ASAs 3 and 4 were identified during shovel test investigations of Section II and are associated with SAL 41HY165 (see Appendix E, Figure E-3). ASA 3 first appeared as a surface scatter of lithic material. Shovel tests excavated in this location revealed intact subsurface deposits. These deposits are located along the southern side of Sink Creek in an area adjacent to the TxState Golf Course's eighth green. Shovel tests excavated in the location of ASA 3 encountered lithic deposits to a depth of $100 \mathrm{cmbs}$. ASA 4, also identified by a surface scatter of lithic material, is located along the southern bank of Sink Creek. The area extends from the "Front Door"/Information Kiosk area, along the East Athletic Fields, and ends at the small peninsula that extends into Spring Lake. Shovel tests excavated here encountered prehistoric deposits to a depth of $80 \mathrm{cmbs}$. The presence of buried, stratigraphically intact cultural deposits in this area was confirmed by the third test unit (XU03), which encountered deposits to a depth of 150 cmbs.

The distribution of prehistoric lithic debitage, bifaces, tools, and projectile points encountered in all these areas was further examined to determine the vertical and horizontal extent of cultural deposits. These distributions were plotted in ArcGIS to create layers displaying cultural deposits at $0-20 \mathrm{cmbs}, 20-40 \mathrm{cmbs}$, 40-60 cmbs, 60-80 cmbs, and 80-100 cmbs (see Appendix E, Figures E-5 through E-9). Together, these distributions reveal the depths of intact cultural deposits in areas that were first identified during shovel test and confirmed by backhoe trench and test unit excavations. These cultural 
deposits have a high potential to be impacted by the proposed undertaking.

As most of the proposed impacts associated with the current undertaking are not projected to impact below $40 \mathrm{cmbs}$, the horizontal and vertical distribution of deposits between 0 and $40 \mathrm{cmbs}$ was also evaluated. These areas (see Appendix E, Figure E-10) will be most directly affected by proposed sod removal, and by construction vehicle traffic and staging as demolition proceeds across the APE.

In addition to these terrestrial investigations, underwater reconnaissance, testing, and sediment coring have concluded that there is a high probability that culturally significant and intact cultural deposits may also be impacted by proposed modifications along shoreline areas and on the bottom of Spring Lake. Areas of concern include the area around the sub and between the sub and the lake bank, and the underwater terrace area located at the western end of the peninsula. These are designated ASAs 5 and 6, respectively, and are attributed to SAL 41HY160 (see Table 6-1, see Appendix E, Figures E-3 and E-11). Cultural material was observed on the lake bottom adjacent to the sub area (see Figures 5-16 though 5-19) and close to the location of the proposed boat ramp during reconnaissance survey (Figures 6-1 through 6-3). While it was not conclusively determined that intact cultural deposits are present in these two areas, our examination of the sediments in these locations indicates a high probability for intact cultural deposits, and revealed undisturbed and highly significant cultural resources nearby.

ASA 5 is defined based on the extensive geologic data derived from a series of sediment cores and complemented by a suite of six radiocarbon assays on organic soil and other materials. This area encompasses what was once the performance area in front of the sub,

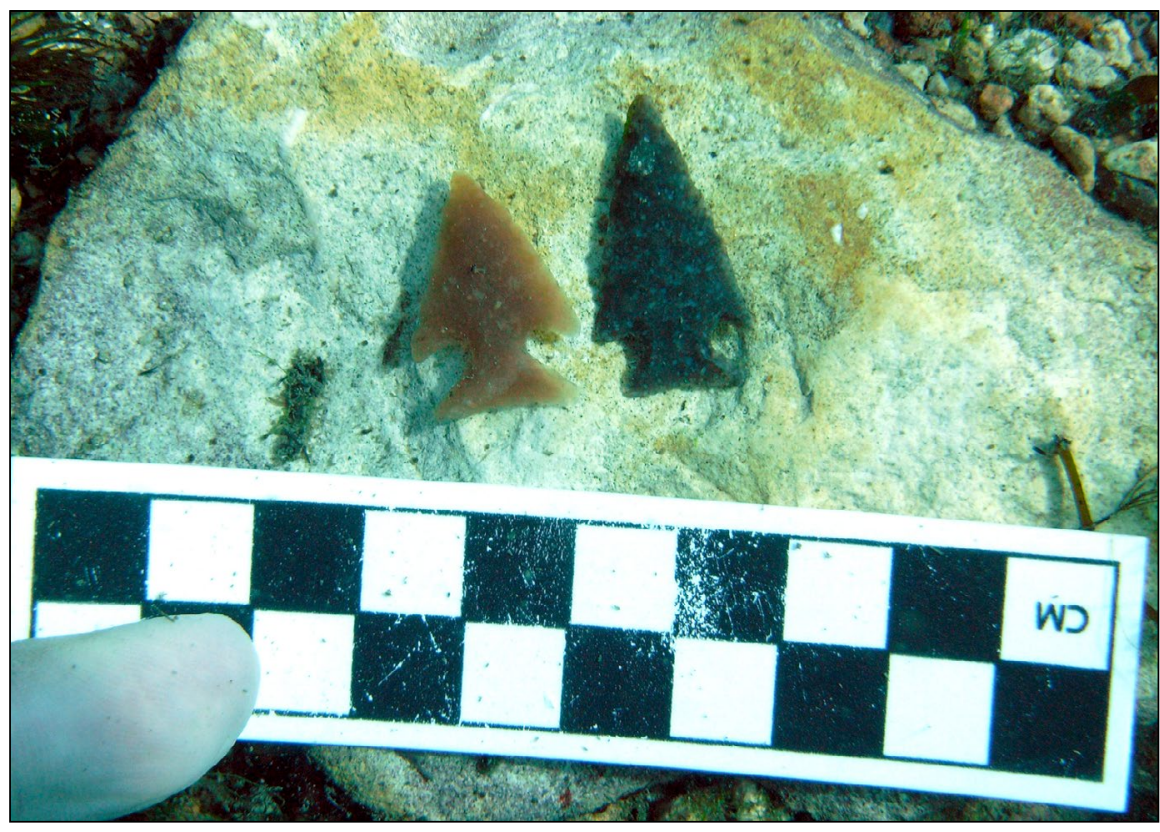

Figure 6-1. Projectile points documented at Deep Hole adjacent to proposed boat ramp location. 


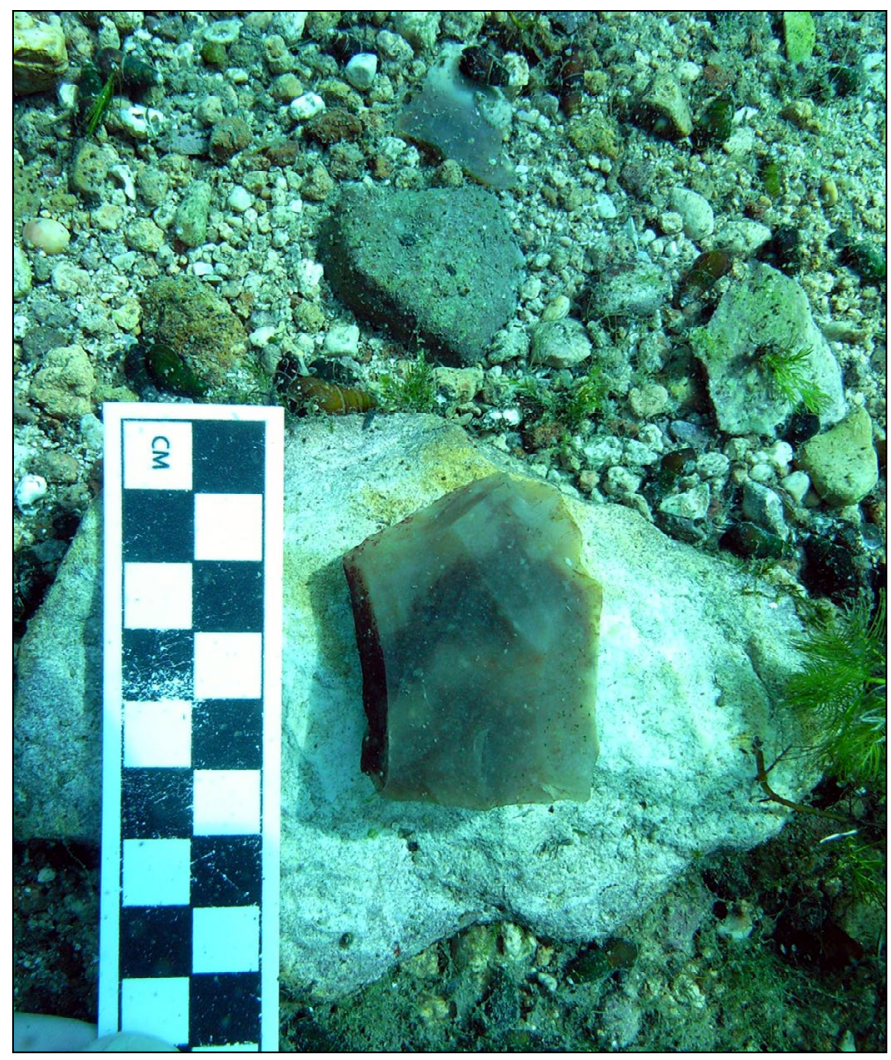

Figure 6-2. Core documented at Deep Hole adjacent to proposed boat ramp location.

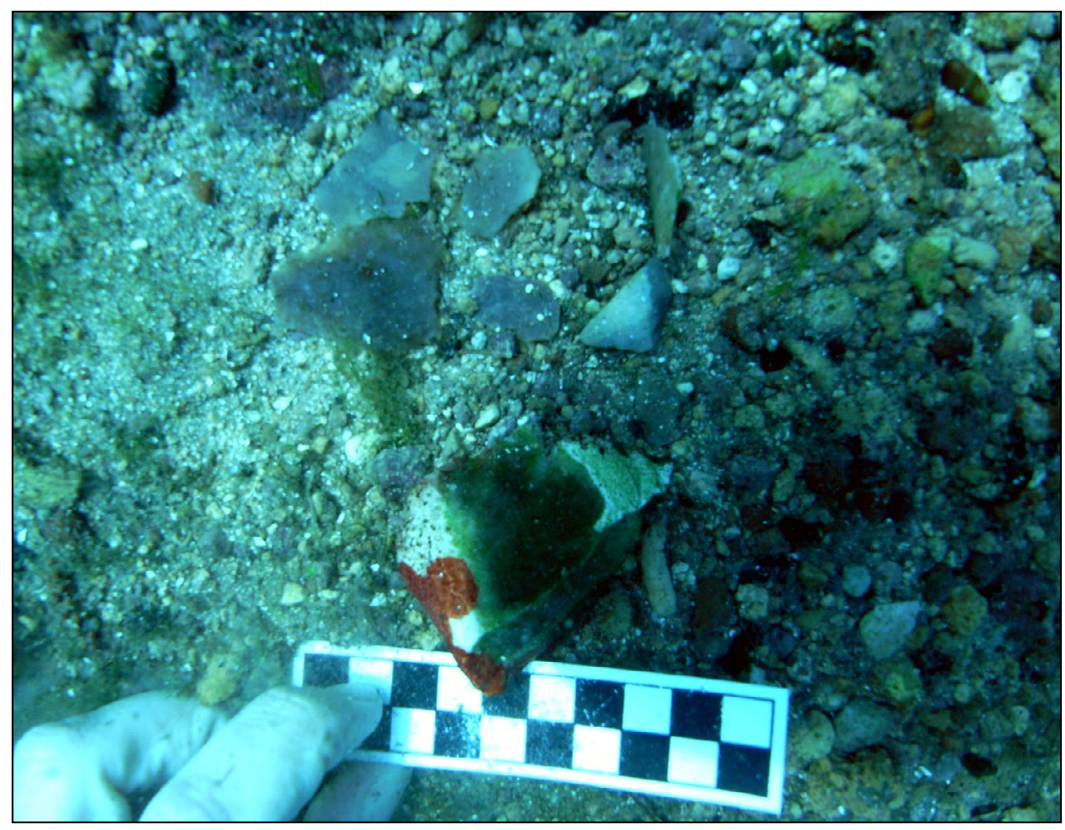

Figure 6-3. Lithic debitage documented at Deep Hole adjacent to proposed boat ramp location. 
and includes all areas to the rear of the sub extending to the bank of Spring Lake. During our work in this locality, no artifacts or cultural materials were observed either on the lake bed or in sediment exposures in the test pit or through coring. However, strata are clearly intact and time-ordered, and reflect typical depositional sequences associated with stream-side settings. Cultural deposits have been recorded nearby and should be expected to occur here as well.

ASA 6 is defined at the end of the Landing and encompasses the spring referred to as Deep Hole (see Appendix D, Figure D-8, and Appendix E, Figure E-11). According to project design information, this area is to be impacted by the construction of a boat ramp extending into the water that will accommodate a barge that will be used to remove dismantled pieces of the sub from the lake. A pair of sediment cores (cores 11 and 12, see Appendix D, Figure D-8) taken from between the shoreline and Deep Hole reveal intact stratigraphy corresponding with portions of the stratigraphic sequence established by cores from around the sub. These two cores were taken from what appears to be a deep, intact alluvial terrace that immediately overlooks Deep Hole. There is abundant cultural material on the lake bed near the spring including projectile points, cores, chipping debris, and more (see Figures 6-1 through 6-3).

\section{Recommendations}

Based on the survey and assessment results presented here, intact cultural resources are clearly present across parts of the APE that will be impacted by the proposed undertaking. In some underwater areas, resources are considered likely to be present though remain unconfirmed. With these results in mind, CAS recommends the development of mitigative measures to offset the loss of important cultural information in identified Archaeologically Sensitive Areas that correspond with parts of SALs $41 \mathrm{HY} 160$ and 41HY165. Mitigative measures proposed for the Spring Lake Aquatic Ecosystem Restoration Project will be presented in the Historic Properties Treatment Plan for the Spring Lake Section 206 Aquatic Ecosystem Restoration Project (forthcoming).

In addition, the site boundaries of archaeological site 41HY165 should be extended to include cultural deposits identified during the recent subsurface survey and testing investigations. As no site boundaries currently exist for archaeological site 41HY160, site boundaries should be established to reflect the limits of current and previous investigations as well as the underwater deposits observed in the northeastern portion of Spring Lake. These site boundaries, depicted in Appendix E, Figure E-4, are based on the results of the current effort. 


\section{References Cited}

Aery, D. A.

2007 Organization of Lithic Technology in Archaic Texas: An Example from 41 HY160 in San Marcos, Texas. Unpublished Master's thesis, Department of Anthropology, Texas State University-San Marcos.

Arnn, John W., III

2005 Chronology, Technology, and Subsistence: Is That All There Is? Council of Texas Archeologists Newsletter 29(2):17-28.

2007 Transformation and Persistence of Indigenous Cultural Identity during the Early Colonial and Late Prehistoric Periods in Texas. Unpublished PhD dissertation, University of Kentucky, Lexington. University Microfilms, Ann Arbor.

Arnn, John W., III, and Karl W. Kibler

1999 Archeological Survey and Geomporphological Assessment for the Proposed Spring Lake Water Line, Hays County, Texas. Technical Reports No. 41. Prewitt and Associates, Inc., Austin.

Batte, C. C.

1984 Soil Survey of Comal and Hays Counties, Texas. United States Department of Agriculture, Soil Conservation Service, in cooperation with the Texas Agricultural Experiment Station.

Birkeland, Peter W.

1999 Soils and Geomorphology. Oxford University Press, Oxford.

Black, Stephen L.

1989 Central Texas Plateau Prairie. In From the Gulf Coast to the Rio Grande: Human Adaptation in the Central, South, and Lower Pecos Texas, edited by Thomas R. Hester, Stephen L. Black, D. Gentry Steele, Ben W. Olive, Anne A. Fox, Karl J. Reinhard, and Leland C. Bement, pp. 17-38. Research Series No. 33. Arkansas Archeological Survey, Fayetteville.

1995 Archeological and Ethnohistorical Background. In Archeological Investigations at the Loma Sandia Site (41LK28): A Prehistoric Campsite in Live Oak County, Texas, Vol. 1, by Anna Jean Taylor and Cheryl Lynn Highley, pp. 31-45. Studies in Archeology No. 20. Texas Archeological Research Laboratory, The University of Texas at Austin.

Black, Stephen L., and Al J. McGraw

1985 The Panther Springs Creek Site: Cultural Change and Continuity in the Upper Salado Creek Drainage, South-Central Texas. Archaeological Survey Report No. 100. Center for Archaeological Research, The University of Texas at San Antonio. 
Bolton, Herbert E.

1970 [1915] Texas in the Middle Eighteenth Century: Studies in Spanish Colonial History and Administration, Vol. 3. University of California Publications in History. University of California, Berkeley.

Bousman, C. Britt, and David L. Nickels, assemblers

2003 Archaeological Testing of the Burleson Homestead at 41HY37, Hays County, Texas. Archaeological Studies Report No. 4. Center for Archaeological Studies, Texas State University-San Marcos.

Bousman, C. Britt, Barry W. Baker, and Anne C. Kerr

2004 Paleoindian Archeology in Texas. In The Prehistory of Texas, edited by Timothy K. Perttula, pp. 15-97. Texas A\&M Press, College Station.

Bousman, C. B., M. B. Collins, P. Goldberg, T. Stafford, J. Guy, B. W. Baker, D. G. Steele, M. Kay, G. Fredlund, P. Dering, S. Dial, V. Holliday, D. Wilson, P. Takac, R. Balinsky, M. Masson, and J. F. Powell

2002 The Paleoindian-Archaic Transition: New Evidence from Texas. Antiquity 76:980-990.

Brune, Gunner

2005 Springs of Texas, Vol 1. Texas A\&M University Press, College Station.

Campbell, T. N., and T. J. Campbell

1985 Indian Groups Associated with Spanish Missions of the San Antonio Missions National Historical Park. Special Report No. 16. Center for Archaeological Research, The University of Texas at San Antonio.

Clark, Jean

1979 Unnamed Form. Texas Historical Commission Texas Archeological Sites Atlas, s.v. “41HY37,” http://nueces.thc.state.tx.us/ (accessed July 6, 2009).

Collins, Michael B.

1994 Evidence of Early Archaic Occupation. In Archaic and Late Prehistoric Human Ecology in the Middle Onion Creek Valley, Hays County, Texas, by Robert A. Ricklis and Michael B. Collins, pp. 67-100. Studies in Archeology 19. Texas Archeological Research Laboratory, The University of Texas at Austin.

1995 Forty Years of Archaeology in Texas. Bulletin of the Texas Archeological Society 66:361400.

2004 Archeology in Central Texas. In The Prehistory of Texas, edited by Timothy K. Perttula, pp. 101-126. Texas A\&M University Press, College Station.

Collins, Michael B., and Kenneth M. Brown

2000 The Gault Gisement: Some Preliminary Observations. Current Archeology in Texas 2(1):163166. 
Crumley, Carole L., editor

1994 Historical Ecology: Cultural Knowledge and Changing Landscapes. School of American Research Press, Santa Fe.

de la Teja, Jesús F.

1995 San Antonio de Bexár: A Community on New Spain's Northern Frontier. University of New Mexico Press, Albuquerque.

Dillehay, Thomas D.

1974 Late Quaternary Bison Population Changes on the Southern Plains. Plains Anthropologist 19(64):180-196.

Dobie, Dudley R.

1932 The History of Hays County, Texas. Unpublished Master's thesis, The University of Texas at Austin.

Dunn, William E.

1911 Apache Relations in Texas, 1718-1750. Southwestern Historical Quarterly 14:198-274.

Fisher, Lewis F.

1998 The Spanish Missions of San Antonio. Maverick Publishing Company, San Antonio.

Ford, O. A., and A. S. Lyle

1998 Archaeological Investigation of a Spring Lake Lot for Joe's Crab Shack Parking. Archaeological Survey Report No. 277. Center for Archaeological Research, The University of Texas at San Antonio.

Foster, William C.

1995 Spanish Expeditions into Texas 1689-1768. University of Texas Press, Austin.

Garber, J. F., S. Bergman, B. Dickinson, R. Hays, III, J. Simpson, and J. Stefanoff

1983 Excavations at Aquarena Springs, San Marcos, Texas. La Tierra 10:2:28-38.

Garber, J. F., and D. M. Glassman

1992 Excavation of Human Remains from the Fish Pond Site, 41HY161, in San Marcos, Hays

County, Texas. Texas Antiquities Permit Number 338. Department of Sociology and Anthropology, Southwest Texas State University, San Marcos.

Garber, J. F., and M. D. Orloff

1984 Excavations at 41HY37: An Archaic Site on the Balcones Escarpment in San Marcos, Texas. La Tierra 11:3:31-37. 
Giesecke, J.

1998 Faunal Analysis from 41HY165: An Independent Study. Manuscript on file, Anthropology Department, Southwest Texas State University, San Marcos.

Goelz, M.

1999 Geoarchaeological Assessment of the Texas Rivers Center, San Marcos Springs. Technical Reports, No. 40. Prewitt \& Associates, Inc., Austin.

Goode, Glenn T.

1989 Archaeological Testing and Recommendations for the Kennedy Bluffs Site, 41BP19, in Bastrop County, Texas, Appendix II. In Excavations at 41BP19, the Kennedy Bluffs Site, Bastrop County, Texas, edited by Leland C. Bement, pp. 155-180. Contract reports in Archaeology, Report 5. Texas State Department of Highways and Public Transportation, Highway Design Division, Austin.

Goudie, Andrew, Malcom Anderson, Tim Burt, John Lewin, Keith Richards, Brian Whalley, and Peter Worsley

1981 Geomorphological Techniques. George Allen \& Unwin, London.

Habig, Marion A.

1977 The Alamo Mission: San Antonio de Valero, 1718-1793. Franciscan Herald Press, Chicago.

Hall, Grant D.

1981 Allens Creek: A Study in the Cultural Prehistory of the Brazos River Valley, Texas. Texas Archaeological Survey Research Report No. 61. The University of Texas at Austin.

Hester, Thomas R.

1983 Late Paleo-Indian Occupations at Baker Cave, Southwestern Texas. Bulletin of the Texas Archeological Society 53:101-119.

1995 The Prehistory of South Texas. Bulletin of the Texas Archeological Society 66:427-459.

2004 The Prehistory of South Texas. In The Prehistory of Texas, edited by Timothy Perttula, pp. 127-151. Texas A\&M University Press, College Station.

Holliday, Vance T.

1997 Paleoindian Geoarchaeology of the Southern High Plains. University of Texas Press, Austin.

Houk, Brett, and Jon Lohse

1993 Archeological Investigations at the Mingo Site, Bandera County, Texas. Bulletin of the Texas Archeological Society 61:193-247.

Huebner, Jeffery A.

1991 Late Prehistoric Bison Populations in Central and Southern Texas. Plains Anthropologist 36(137):343-358. 
Johnson, LeRoy, Jr.

1994 The Life and Times of Toyah-Culture Folk; the Buckhollow Encampment Site 41KM16, Kimble County, Texas. Office of State Archeologist Report 38. Texas Department of Transportation and the Texas Historical Commission, Austin.

Johnson, LeRoy, Jr., and T. N. Campbell

1992 Sanan: Traces of a Previously Unknown Aboriginal Language in Colonial Coahuila and Texas. Plains Anthropologist 37(140):185-212.

Johnson, LeRoy, Jr., and Glenn T. Goode

1994 A New Try at Dating and Characterizing Holocene Climates, as well as Archeological Periods, on the Eastern Edwards Plateau. Bulletin of the Texas Archeological Society 65:1-51.

Johnson, Eileen, and Vance T. Holliday,

1984 Comments on "Large Springs and Early American Indians" by Joel L. Shiner. Plains Anthropologist 29(103):65-70.

Jones, Richard

2002 Archaeological Trench Monitoring Near Prehistoric Site 41HY161, Hays County, Texas. Technical Report No. 3. Center for Archaeological Studies, Texas State University-San Marcos.

Kelley, J. Charles

1947 The Lehmann Rock Shelter: A Stratified Site of the Toyah, Uvalde, and Round Rock Foci. Bulletin of the Texas Archeological and Paleontological Society 18:115-128.

Leezer, Carole, Julian A. Sitters, and Sarah Scogin

2010 Archaeological Assessment and Monitoring for Construction of a New Boiler Station at Jowers Center and Sewell Park, Texas State University-San Marcos, Hays County, Texas. Technical Report No. 38. Center for Archaeological Studies, Texas State University-San Marcos.

Lemke, Ashley, and Cinda Timperley

2008 Preliminary Analysis of Turtle Material from the Gault Site, Texas. Current Research in the Pleistocene 25:115-117.

Lohse, Jon C.

1999 Lithics from the San Antonio de Valero Mission: Analysis of Materials for the 1979 Excavations of the Alamo. Bulletin of the Texas Archeological Society 70:265-279.

Lukowski, Paul D., with contributions by Robert F. Scott IV and Richard F. Shoup

1988 Archaeological Investigations at 41BX1, Bexar County, Texas. Archaeological Survey Report No. 135. Center for Archaeological Research, The University of Texas at San Antonio. 
Lyle, A., C. Horrell, S. A. Tomka, and D. A. Cargill

2000 Archaeological Testing at the Headwaters of the San Marcos River: Southwest Texas State University Raw Water Supply Project. Archaeological Survey Report No. 293. Center for Archaeological Research, The University of Texas at San Antonio.

McClure, W. L.

1970 Archeological Site Survey Record-State of Texas. Texas Historical Commission Texas

Archeological Sites Atlas, s.v. “41HY37,” http://nueces.thc.state.tx.us/ (accessed July 6, 2009).

McGraw, Al J., John W. Clarke, Jr., and Elizabeth A. Robbins (editors)

1991 A Texas Legacy: The Old San Antonio Road and the Caminos Reales, A Tricentennial History, 1691-1991. Texas State Department of Highways and Public Transportation, Austin.

Munoz, Cynthia M., Raymond Mauldin, and Robert J. Hard

2011 Stable Isotope Analysis of Human Skeletal Remains from 41HY163, with Comparative Analyisis of Remains from 41HY161. In Prehistoric Life, Labor, and Residence in SoutheastCentral Texas: Results of Data Recovery at 41HY163, the Zatopec Site, San Marcos, Texas, edited by Jon C. Lohse, pp. 343-350. Archaeological Studies Report No. 18. Center for Archaeological Studies, Texas State University-San Marcos.

Newcomb, William W., Jr.

1961 The Indians of Texas From Prehistoric to Modern Times. University of Texas Press, Austin. 1993 Historic Indians of Central Texas. Bulletin of the Texas Archeological Society 64:1-63.

Nickels, David L., and C. Britt Bousman (assemblers)

2010 Texas River Center Archaeology, Test Excavations at 41HY160, Hays County, Texas. Archaeological Studies Report No. 13. Center for Archaeological Studies, Texas State University-San Marcos.

Nordt, L.

2010 Chapter 6: Geology, Landscape Evolution, and Geoarchaeology. In Texas River Center Archaeology, Test Excavations at 41HY160, Hays County, Texas, assembled by David L. Nickels and C. Britt Bousman, pp. 47-60. Archaeological Studies Reports No. 13. Center for Archaeological Studies, Texas State University-San Marcos.

Oksanen, Eric

2006 Proposed Fiber Optic Conduit Route at the Aquarena River Center and Golf Course, San Marcos, Hays County, Texas. Technical Report No. 22. Center for Archaeological Studies, Texas State University-San Marcos.

2008 Archaeological Investigations at the Icehouse Site, 41HY161: A Revaluation of Early Archaic Technology, Subsistence, and Settlement along the Balcones Escarpment and Central Texas. Unpublished Master's thesis, Department of Anthropology, Texas State University-San Marcos. 
Patterson, Leland W.

1995 The Archeology of Southeast Texas. Bulletin of the Texas Archeology Society 66:239-264.

Prewitt, Elton R.

1974 Preliminary Archeological Investigations in the Rio Grande Delta Area of Texas. Bulletin of the Texas Archeological Society 45:55-65.

Ramsey, D.

1997 Archaeological Survey of Aquarena Springs Park, Hays County, Texas. Manuscript on file, Anthropology Department, Southwest Texas State University, San Marcos.

Ricklis, Robert A.

1994 Toyah Components: Evidence for Occupation in the Project Area During the Latter Part of the Late Prehistoric Period. In Archaic and Late Prehistoric Human Ecology in the Middle Onion Creek Valley, Hays County, Texas, by Robert A. Ricklis and Michael B. Collins, pp. 207-316. Studies in Archeology 19. Texas Archeological Research Laboratory, The University of Texas at Austin.

2005 Analysis of Findings at the Buckeye Knoll Site (41TV98), Victoria County, Texas. Quarterly Report No. 5. Report submitted to the United States Army Corps of Engineers. Electronic document, http://www.swg.usace.army.mil/pe/41VT98/ (accessed 1 September, 2009).

Ringstaff, C. W.

2000 A Study of Landform Evolution and Archaeological Preservation at Site 41HY165, San Marcos, Texas. Unpublished Master's thesis, Department of Geography, Southwest Texas State University, San Marcos.

Schaetzl, Randall, and Sharon Anderson

2005 Soils: Genesis and Geomorphology. Cambridge University Press, Cambridge.

Shiner, J. L.

1979 Survey and Testing of the Ice House Site: San Marcos, Hays County, Texas. Unpublished manuscript on file, Southern Methodist University, Dallas.

1981 History, Economy, and Magic at a Fresh Water Spring. In The Realms of Gold, Proceedings of the Tenth Conference on Underwater Archaeology, edited by W. A. Cockrell, pp. 202-203. Fathom Eight, San Marino, California.

1983 Large Springs and Early American Indians. Plains Anthropologist 28:99:1-7.

1984 A Reply of Johnson and Holliday. Plains Anthropologist 29:103:71-72.

Soucie, Shawn, and David L. Nickels

2003 Archaeological Monitoring of a Tree Planting Project and Installation of the Front Door Welcoming Drive for Texas State University-San Marcos, Hays County, Texas. Technical Report No. 11. Center for Archaeological Studies, Texas State University-San Marcos. 
Soucie, Shawn, David L. Nickels, Kevin L. Shubert, and Colby J. Mischefsky

2004 Archaeological Trench Monitoring at the Aquarena Springs Golf Course, San Marcos, Hays County, Texas. Technical Report No. 16. Center for Archaeological Studies, Texas State University-San Marcos.

Stanford, Dennis, and Frank Broilo

1981 Frank's Folsom Campsite. The Artifact 19(3-4):1-11.

Story, Dee Ann

1985 Adaptive Strategies of Archaic Cultures of the West Gulf Coastal Plain. In Prehistoric Food Production in North America, edited by Richard I. Ford, pp. 19-56. Anthropological Papers No. 75. Museum of Anthropology, University of Michigan, Ann Arbor.

Stull, Kyra, and Michelle D. Hamilton

2011 Descriptive Analysis of Skeletal Remains of Three Individuals from Zatopec, with Comparative Analysis of Two Additional Sets from 41HY161. In Prehistoric Life, Labor, and Residence in Southeast-Central Texas: Results of Data Recovery at 41HY163, the Zatopec Site, San Marcos, Texas, edited by Jon. C. Lohse, pp. 337-342. Archaeological Studies Report No. 18. Center for Archaeological Studies, Texas State University-San Marcos.

Takac, P. R.

1990 "Homes Bases" and the Paleoindian/Archaic transition in Central Texas. Paper presented at the 55th Annual SAA Meeting, Las Vegas, Nevada.

1991a Underwater Excavations at Spring Lake: A Paleoindian site in Hays County, Texas. Current Research in the Pleistocene 8:46-48.

1991b Paleoindian Occupations at Spring Lake, Hays Co., Texas. Dissertation Research Proposal. Submitted to the Faculty, Department of Anthropology, Southern Methodist University, Dallas.

Texas Historical Commission [THC]

1987 State Archeological Landmark Form. Texas Historical Commission Texas Archeological Sites Atlas, s.v. “41HY161,” http://nueces.thc.state.tx.us/ (accessed July 6, 2009).

1999a State Archeological Landmark Form. Texas Historical Commission Texas Archeological Sites Atlas, s.v. “41HY37,” http://nueces.thc.state.tx.us/ (accessed July 6, 2009).

1999b State Archeological Landmark Form. Texas Historical Commission Texas Archeological Sites Atlas, s.v. “41HY147,” http://nueces.thc.state.tx.us/ (accessed July 6, 2009).

1999c State Archeological Landmark Form. Texas Historical Commission Texas Archeological Sites Atlas, s.v. “41HY160," http://nueces.thc.state.tx.us/ (accessed July 6, 2009).

Turner, Ellen S., and Thomas R. Hester

1993 A Field Guide to Stone Artifacts of Texas Indians. 2nd ed. Texas Monthly Field Guide Series. Gulf Publishing Company, Houston. 
Weir, Frank A.

1976 The Central Texas Archaic. Unpublished PhD dissertation, Anthropology Department, Washington State University, Pullman.

Wenke, Robert J.

1990 Patterns in Prehistory: Humankind's First Three Million Years. 3rd ed. Oxford University Press, Oxford, England.

Yelacic, David M., and Jon. C. Lohse

2010 Results of Archaeological Survey at the 251-acre Spring Lake Preserve, San Marcos, Hays County, Texas. Technical Report No. 41. Center for Archaeological Studies, Texas State University-San Marcos.

Yelacic, David M., R. Zac Selden, and Jon C. Lohse

2008 Results of Archaeological Monitoring at the Fish Ponds, Texas State University-San Marcos, Hays County, Texas. Technical Report No. 33. Center for Archaeological Studies, Texas State University-San Marcos. 


\section{Appendix A}

\section{Core Descriptions}

\section{David Yelacic}

The following tables supply technical descriptions for a total of ten sediment cores extracted around and near the submersible theatre along the southern bank of Spring Lake. Coring methods consisted of driving 2.5-inch PVC pipe into the lake bed with a very large post driver (slide hammer), capping and removing the sediment cores and transporting them to the Center for Archaeological Studies, draining excess water within each core, and exposing the sediment with longitudinal cuts on opposite sides of each PVC pipe. Once exposed, characteristics, including depth, color, texture, structure, consistency, and geologic, pedogenic, and biogenic features of the sediments were recorded. Measurements below are recorded in centimeters from the bottom to the top of each core, because of the core not being completely full and sediment consistently being present at the bottom-it is not clear whether the sediment was compacted by the physics of core-driving, or if the sediment at the bottom of each core acted as a plug displacing sediment below.

\section{Core 1, Site 2}

Location: Site 2 is on the north side of the westernmost portion of the sub.

\begin{tabular}{|c|c|c|}
\hline Zone & $\begin{array}{l}\text { Depth } \\
\text { (cmbs) }\end{array}$ & Description \\
\hline 1 & $41-48$ & $\begin{array}{c}\text { Black (7.5YR 2.5/1) silty loam; no apparent structure; very abrupt smooth lower } \\
\text { boundary; violently effervescent, common dark yellowish-brown (10YR 4/6) mottles; } \\
<2 \% \text { coarse fragments; common fine shell fragments }\end{array}$ \\
\hline 2 & $29-41$ & $\begin{array}{c}\text { Very dark grayish-brown }(10 \mathrm{YR} 3 / 2) \text { silty clay; no apparent structure; abrupt smooth } \\
\text { lower boundary; violently effervescent; }<1 \% \text { coarse fragments; very wet after sitting out } \\
\text { for a day }\end{array}$ \\
\hline 3 & $19-29$ & $\begin{array}{l}\text { Black (7.5YR 2.5/1) silty loam; no apparent structure; abrupt smooth lower boundary; } \\
\text { violently effervescent; }<2 \% \text { coarse fragments; common fin shell fragments }\end{array}$ \\
\hline 4 & $13-19$ & $\begin{array}{c}\text { Very dark gray }(7.5 \mathrm{YR} 3 / 1) \text { silty loam; no apparent structure; very abrupt smooth lower } \\
\text { boundary; violently effervescent; }<1 \% \text { coarse fragments; at least one visible piece of } \\
\text { well-preserved organic matter }\end{array}$ \\
\hline 5 & $13-5$ & $\begin{array}{l}\text { Very dark brown (10YR } 2 / 2) \text { silty loam; no apparent structure; abrupt smooth lower } \\
\text { boundary; violently effervescent; }<5 \% \text { coarse fragments; common fine shell fragments }\end{array}$ \\
\hline 6 & $5-0$ & $\begin{array}{l}\text { Very dark gray (10YR 3/1) silty loam; violently effervescent; }<1 \% \text { coarse fragments; } \\
\text { common fine shell fragments }\end{array}$ \\
\hline
\end{tabular}




\section{Core 2, Site 2}

Location: Site 2 is on the north side of the westernmost portion of the sub.

Remarks: This is the second core extracted from this location.

\begin{tabular}{|c|c|c|}
\hline Zone & $\begin{array}{l}\text { Depth } \\
\text { (cmbs) }\end{array}$ & Description \\
\hline 1 & $50-62$ & $\begin{array}{c}\text { Very dark grayish-brown (10YR 3/2) silty loam; no apparent structure; very abrupt lower } \\
\text { boundary; violently effervescent; few rootlets; <1\% coarse fragments; few fine shell } \\
\text { fragments }\end{array}$ \\
\hline 2 & $49-50$ & $\begin{array}{l}\text { Light brownish-gray (2.5Y 6/2) sandy loam; no apparent structure; very abrupt smooth } \\
\text { lower boundary; violently effervescent; }<1 \% \text { coarse fragments; very thin laminae on top } \\
\text { and bottom (Zone } 4 \text { ) of organic matter (Zone } 3 \text { ) }\end{array}$ \\
\hline 3 & $46-49$ & $\begin{array}{l}\text { Black (10YR 2/1) clay loam; no apparent structure; very abrupt smooth lower boundary; } \\
\text { violently effervescent; }<1 \% \text { coarse fragments; organic rich! }\end{array}$ \\
\hline 4 & $44-46$ & $\begin{array}{l}\text { Light brownish-gray ( } 2.5 \mathrm{Y} \text { 6/2) sandy loam; no apparent structure; very abrupt smooth to } \\
\text { wavy(?) lower boundary; violently effervescent; }<1 \% \text { coarse fragments; similar to Zone } 2\end{array}$ \\
\hline 5 & $35-44$ & $\begin{array}{c}\text { Very dark brown ( } 10 \mathrm{YR} 2 / 2) \text { silt loam; no apparent structure; abrupt smooth lower } \\
\text { boundary; violently effervescent; <5\% coarse fragments; small gravels near upper } \\
\text { boundary; common fine shell fragments }\end{array}$ \\
\hline 6 & $26-35$ & $\begin{array}{l}\text { Very dark grayish-brown (10YR 3/2) clay loam; no apparent structure; abrupt smooth } \\
\text { lower boundary; violently effervescent; Same as Zone 2, Core 1, Site 2; sampled: SLC-2- } \\
\qquad 2-1(28-35 \mathrm{~cm}, 144.79 \mathrm{~g})\end{array}$ \\
\hline 7 & $18-26$ & $\begin{array}{l}\text { Very dark gray }(10 \mathrm{YR} 3 / 1) \text { clay loam; no apparent structure; abrupt smooth lower } \\
\text { boundary; violently effervescent; }<1 \% \text { coarse fragments; some possible organic material; } \\
\text { wetter than other sediments, taking into account that all have been exposed for }>24 \text { hours }\end{array}$ \\
\hline 8 & $4-18$ & $\begin{array}{l}\text { Very dark grayish-brown (10YR 3/2) clayey loam; no apparent structure; very abrupt } \\
\text { smooth lower boundary; violently effervescent; few rootlets; common fine shell } \\
\text { fragments; sampled: SLC-2-2-6 }(5-12 \mathrm{~cm}, 83.88 \mathrm{~g})\end{array}$ \\
\hline 9 & $0-4$ & $\begin{array}{c}\text { Very dark grayish-brown (10YR } 3 / 2) \text { silty loam; weak to moderate fine subangular blocky } \\
\text { structure; violently effervescent; clay coats on clasts; }>20 \% \text { coarse fragments; common } \\
\text { strong brown ( } 7.5 \text { YR } 5 / 8) \text { mottling or transition to reddish gravelly stratum-not enough } \\
\text { sediment to be sure }\end{array}$ \\
\hline
\end{tabular}




\section{Core 3, Site 3}

Location: Site 3 is located on the north side of the eastern portion of the sub.

\begin{tabular}{|c|c|c|}
\hline Zone & $\begin{array}{l}\text { Depth } \\
\text { (cmbs) }\end{array}$ & Description \\
\hline 1 & $27-40$ & $\begin{array}{c}\text { Very dark gray (10YR 3/1) clay loam; no apparent structure; abrupt smooth lower } \\
\text { boundary; violently effervescent; clay coats on clasts; } 15 \% \text { coarse fragments; common } \\
\text { dark yellowish-brown (10YR } 4 / 4) \text { mottles }\end{array}$ \\
\hline 2 & $18-27$ & $\begin{array}{l}\text { Very dark gray (10YR 3/1) silty loam; no apparent structure; abrupt smooth lower } \\
\text { boundary; violently effervescent; clay and carbonate(?) cotas on clasts; } 20 \% \text { coarse } \\
\text { fragments; common yellowish-brown (10YR 5/6) mottles; sample: SLC-3-3-7 (18-25 cm, } \\
158.30 \mathrm{~g})\end{array}$ \\
\hline 3 & $10-18$ & $\begin{array}{l}\text { Very dark gray (10YR 3/1) clay loam; no apparent structure; very abrupt smooth lower } \\
\text { boundary; violently effervescent; clay and carbonate(?) coats on clasts; }>50 \% \text { coarse } \\
\text { fragment, matrix supported; common dark yellowish-brown (10YR 4/4) mottles }\end{array}$ \\
\hline 4 & $3-10$ & $\begin{array}{l}\text { Very dark grayish-brown (10YR 3/2) sandy loam; no apparent structure; very abrupt } \\
\text { smooth lower boundary; violently effervescent; < } 1 \% \text { coarse fragments; few yellowish- } \\
\text { brown (10YR 5/6) mottles; sample: SLC-3-3-2 }(0-8 \mathrm{~cm}, 106.26 \mathrm{~g})\end{array}$ \\
\hline 5 & $0-3$ & $\begin{array}{l}\text { Light olive brown (10YR 5/3) silty loam; no apparent structure; violently effervescent; } \\
\text { clay and carbonate(?) coats on clasts; } 50 \% \text { coarse fragments, matrix supported }\end{array}$ \\
\hline
\end{tabular}

\section{Core 7, Site 6}

Location: Site 6 is located off the north end of the westernmost portion of the sub; contrasting to the other core locations, this one had thick vegetation.

Remarks: This particular sample was especially difficult to remove.

\begin{tabular}{|c|c|c|}
\hline Zone & $\begin{array}{l}\text { Depth } \\
\text { (cmbs) }\end{array}$ & Description \\
\hline 1 & $58-69$ & $\begin{array}{l}\text { Dark grayish-brown (10YR 4/2) silty loam; no apparent structure; very abrupt lower } \\
\text { boundary; violently effervescent; } 10 \% \text { coarse fragments common strong brown ( } 7.5 \mathrm{YR} \\
5 / 6) \text { mottles }\end{array}$ \\
\hline 2 & $53-58$ & $\begin{array}{l}\text { Very dark brown (10YR } 2 / 2) \text { loam; no apparent structure; very abrupt lower boundary; } \\
80 \% \text { coarse fragments, clast supported; interpreted as historic/modern pea-gravel fill }\end{array}$ \\
\hline 3 & $31-53$ & $\begin{array}{l}\text { Dark yellowish-brown (10YR 4/6) clay loam; strong medium subangular blocky; firm; } \\
\text { very abrupt lower boundary; violently effervescent; clay coats on clasts; fine carbonate } \\
\text { nodules; } 30 \% \text { coarse fragments; sample: SLC-7-6-3 ( } 40-48 \mathrm{~cm}, 192.78 \mathrm{~g})\end{array}$ \\
\hline 4 & $0-31$ & $\begin{array}{c}\text { Dark yellowish-brown (10YR 4/6) clay loam; strong medium subangular blocky; } \\
\text { extremely firm; violently effervescent; fine carbonate nodules; <15\% coarse fragments; } \\
\text { this zone was only damp when opened-very compact and exhibiting well-developed ped } \\
\text { structure; sample: SLC-7-6 }(20-27 \mathrm{~cm}, 198.96 \mathrm{~g})\end{array}$ \\
\hline
\end{tabular}




\section{**Note that the following six core descriptions are the result of a second phase of coring, which included investigating the bank-side of the sub as well as the end of the peninsula.**}

\section{Core 8, Site 7}

Location: Site 7 is located behind the west end of the sub.

Remarks: Sediment is contained in the bottom foot of a 4-ft coring tube (tube was inserted much more).

\begin{tabular}{|c|c|c|}
\hline Zone & $\begin{array}{l}\text { Depth } \\
\text { (cmbs) }\end{array}$ & Description \\
\hline 1 & $0-32$ & $\begin{array}{c}\text { Strong brown (7.5YR 4/6) clay; moderate medium blocky structure; friable; violently } \\
\text { effervescent; fine nodular and filamental carbonate increased in lower } 12 \mathrm{~cm} ;<1 \% \\
\text { coarse fragments; common clay coats on ped faces and in pore spaces; }<1 \% \text { possible } \mathrm{Mn} \\
\text { nodules; } 30 \% \text { oxidation features }\end{array}$ \\
\hline
\end{tabular}

\section{Core 9, Site 8}

Location: Site 8 was located just west of access bridge on south side of the sub.

Remarks: Sediment contained in the bottom third of 4-ft coring tube (tube was inserted much more).

\begin{tabular}{|c|c|c|}
\hline Zone & $\begin{array}{l}\text { Depth } \\
\text { (cmbs) }\end{array}$ & Description \\
\hline 1 & $35-48$ & $\begin{array}{l}\text { Dark yellowish-brown (10YR 4/4) clay; weak medium blocky structure; friable; abrupt } \\
\text { lower boundary; violently effervescent; common faint clay coats on ped faces; } 3 \% \text { coarse } \\
\text { fragments; round pebbles at very top of core-interpreted as historic/modern pea-gravel } \\
\text { fill }\end{array}$ \\
\hline 2 & $21-35$ & $\begin{array}{l}\text { Dark brown (7.5YR } 3 / 4) \text { clay; moderate medium blocky structure; friable; clear lower } \\
\text { boundary; violently effervescent; filament carbonate; common fain clay coats on ped } \\
\qquad \text { faces; }<2 \% \text { coarse fragments; }\end{array}$ \\
\hline 3 & $11-21$ & $\begin{array}{l}\text { Yellowish-brown (10YR 5/6) clay; moderate medium blocky structure; friable; clear lower } \\
\text { boundary; filament and fine nodular carbonates; common faint clay coats on ped faces; } \\
\qquad 10 \% \text { coarse fragments (carbonate nodules) }\end{array}$ \\
\hline 4 & $0-11$ & $\begin{array}{l}\text { Yellowish-brown (10YR } 5 / 6) \text { clay; moderate medium blocky structure; friable; common } \\
\text { clay coats on ped faces; } 10 \% \mathrm{Mn} \text { concretions; }<1 \% \text { coarse fragments }\end{array}$ \\
\hline
\end{tabular}




\section{Core 10, Site 9}

Location: Site 9 is located on the southeast side of the sub, to the east of the access bridge. Remarks: Sediment is contained in the lower approximately $2 \mathrm{ft}$ of a 6 -ft core tube.

\begin{tabular}{|c|c|c|}
\hline Zone & $\begin{array}{l}\text { Depth } \\
\text { (cmbs) }\end{array}$ & Description \\
\hline 1 & $63-73$ & $\begin{array}{l}\text { Approximately } 80 \% \text { black clay (10YR } 2 / 1 \text { ) clay loam and } 20 \% \text { dark yellowish-brown } \\
\text { (10YR 4/4) clay, a mixture of Zones } 3 \text { and } 4 \text {, respectively; structureless; friable; abrupt } \\
\text { lower boundary; } 40 \% \text { coarse fragments, including historic/modern pea-gravel fill }\end{array}$ \\
\hline 2 & $38-63$ & $\begin{array}{c}\text { Approximately } 55 \% \text { black clay }(10 \mathrm{YR} 2 / 1) \text { clay loam and } 45 \% \text { dark yellowish-brown } \\
\text { (10YR 4/4) clay, a mixture of Zones } 3 \text { and } 4 \text {, respectively; structureless; friable; abrupt } \\
\text { lower boundary; }<5 \% \text { coarse fragments }\end{array}$ \\
\hline 3 & $28-38$ & $\begin{array}{c}\text { Black (10YR 2/1) clay loam; structureless to very weak fine blocky structure; very friable; } \\
\text { very abrupt lower boundary; } 10 \% \text { coarse fragments; common shell fragments, }<2 \mathrm{~mm}, 1 \\
\text { bivalve, } 1 \text { fine ramshorn; contains at least one charcoal fleck }\end{array}$ \\
\hline 4 & $12-28$ & $\begin{array}{l}\text { Dark yellowish-brown (10YR 4/4) clay; weak medium blocky structure; friable; abrupt } \\
\text { lower boundary; uncommon discontinuous faint fine redox features (masses/depletions); } \\
<1 \% \text { coarse fragments; sample: SLC-9-3 }(22-26 \mathrm{~cm}, 52.82 \mathrm{~g})\end{array}$ \\
\hline 5 & $0-12$ & $\begin{array}{c}\text { Dark yellowish-brown (10YR } 4 / 4) \text { clay; moderate medium blocky structure; friable; } 10 \% \\
\text { carbonate fine nodules and filaments; }<10 \% \text { redox features (masses/coats); }<10 \% \text { clay } \\
\text { faint clay coats; }<3 \% \text { coarse fragments }\end{array}$ \\
\hline
\end{tabular}

\section{Core 11, Site 10}

Location: Site 10 is the easternmost sample, and is located between the glass-bottom boat dock and the east end of the sub.

Remarks: Sediment is contained in the lower $2.5 \mathrm{ft}$ of a 6 - $\mathrm{ft}$ core tube.

\begin{tabular}{|c|c|c|}
\hline Zone & $\begin{array}{l}\text { Depth } \\
\text { (cmbs) }\end{array}$ & Description \\
\hline 1 & $50-75$ & $\begin{array}{l}\text { Black (5Y 2.5/2) clay loam; structureless; friable; abrupt lower boundary; effervescent; } \\
\text { abundant roots; } 5 \% \text { coarse fragments; modern accumulation }\end{array}$ \\
\hline 2 & $34-50$ & $\begin{array}{c}\text { Very dark grayish-brown (2.5Y 3/2) clay loam; structureless; very friable; abrupt lower } \\
\text { boundary; effervescent; } 20 \% \text { coarse fragments, common roots; including historic/modern } \\
\text { pea-gravel fill; great amount of well-preserved organic matter }\end{array}$ \\
\hline 3 & $27-34$ & $\begin{array}{l}\text { Very dark grayish-brown ( } 2.5 \text { Y } 3 / 2) \text { clay loam; structureless; very friable; abrupt smooth } \\
\text { lower boundary; effervescent; similar to Zone } 2 \text {, but without gravel }\end{array}$ \\
\hline 4 & $17-27$ & $\begin{array}{l}\text { Black (10YR 2/1) clay loam; weak medium blocky structure; very friable; effervescent; } \\
\text { very abrupt and irregular lower boundary; } 3 \% \text { coarse fragments; sample: SLC-10-4 } \\
\qquad(20-24 \mathrm{~cm}, 41.69 \mathrm{~g})\end{array}$ \\
\hline 5 & $12-17$ & Approximately $65 \%$ Zone 6 and $35 \%$ Zone 4 \\
\hline 6 & $0-12$ & $\begin{array}{l}\text { Strong brown ( } 7.5 \text { YR } 4 / 6 \text { ) clay; weak medium blocky structure; firm; common fine } \\
\text { carbonate nodules; uncommon faint redox features; }<2 \% \text { coarse fragments }\end{array}$ \\
\hline
\end{tabular}




\section{Core 12, Site 11}

Location: Site 11 is approximately $10 \mathrm{~m}$ off the west end of the peninsula.

Remarks: Sediments contained in the bottom approximately $4 \mathrm{ft}$ of a 10 -ft core.

\begin{tabular}{|c|c|c|}
\hline Zone & $\begin{array}{l}\text { Depth } \\
\text { (cmbs) }\end{array}$ & Description \\
\hline 1 & $96-136$ & $\begin{array}{l}\text { Black (5Y 2.5/2) loam; structureless; loose; clear lower boundary; spongey texture; } \\
\text { abundant roots; } 1 \% \text { coarse fragments }\end{array}$ \\
\hline 2 & $75-96$ & $\begin{array}{l}\text { Very dark gray }(2.5 \mathrm{Y} 3 / 1) \text { loam; stuctureless; loose (very wet); clear lower boundary; } \\
\text { common roots; }<1 \% \text { coarse fragments; } 2-5 \% \text { snails, hydrobiidae and very small physidae } \\
\text { (both freshwater); spongey }\end{array}$ \\
\hline 3 & $52-75$ & Same as Zone 2; clear lower boundary \\
\hline 4 & $23-52$ & $\begin{array}{l}\text { Black (10YR 2/1) clay loam; weak fine blocky structure; very friable; abrupt lower } \\
\text { boundary; common roots; <2\% coarse fragments; common well-preserved organic } \\
\text { material; } 5 \% \text { snail shell fragments, including hydrobiidae; few faint fine mottles lighter in } \\
\text { color }\end{array}$ \\
\hline 5 & $22-23$ & $\begin{array}{l}\text { Very dark gray ( } 2.5 \mathrm{Y} 3 / 1) \text { clay loam; structureless; very friable (wet); very abrupt lower } \\
\text { boundary; < } 1 \% \text { coarse fragments; slightly lighter and much "cleaner" than Zones } 6 \text { and } 8\end{array}$ \\
\hline 6 & $20-22$ & $\begin{array}{l}\text { Very dark gray (10YR } 3 / 1) \text { clay; weak fine blocky structure; very friable (wet); abrupt } \\
\text { lower boundary; } 10 \% \text { coarse fragments; sagdidae snail present (terrestrial) }\end{array}$ \\
\hline 7 & $18-20$ & Same as Zone 5; abrupt lower boundary \\
\hline 8 & $14-18$ & $\begin{array}{c}\text { Same as Zone 6; very abrupt irregular lower boundary; contains weathered/burned } \\
\text { limestone gravel ( }<5 \mathrm{~mm} \text { dia.); valloniidae snail present (terrestrial), } 5 \% \text { snail fragments; } \\
\text { sample: SLC-11-2 (14-18 cm, } 37.35 \mathrm{~g})\end{array}$ \\
\hline 9 & $0-14$ & $\begin{array}{c}\text { Olive brown }(2.5 \mathrm{Y} 4 / 4) \text { clay; moderate fine-medium blocky structure; very friable; } \\
\text { common fine carbonate filament and nodules; } 1 \% \text { coarse fragments; few fine faint redox } \\
\text { features; sample: SLC- } 11-1(8-12 \mathrm{~cm}, 59.37 \mathrm{~g})\end{array}$ \\
\hline
\end{tabular}




\section{Core 13, Site 12}

Location: Site 12 is located approximately $5 \mathrm{~m}$ northwest of Site 11, off the western end of the peninsula Remarks: Sediment is contained in bottom $4 \mathrm{ft}$ of 10 -ft core.

\begin{tabular}{|c|c|c|}
\hline Zone & $\begin{array}{l}\text { Depth } \\
\text { (cmbs) }\end{array}$ & Description \\
\hline 1 & $99-146$ & $\begin{array}{c}\text { Black (5Y 2.5/2) loam; stuctureless; loose (very wet); abrupt lower boundary; }<1 \% \text { coarse } \\
\text { fragments; abundant roots; } 1 \% \text { shell fragments; spongey }\end{array}$ \\
\hline 2 & $94-99$ & $\begin{array}{c}\text { Black (10YR 2/1) clay loam; structureless; loose; abrupt lower boundary; few roots; }<1 \% \\
\text { coarse fragments; aromatic and spongey }\end{array}$ \\
\hline 3 & $92-94$ & $\begin{array}{c}\text { Dark olive gray (5Y 3/2) loam; structureless; loose; abrupt lower boundary; }<1 \% \text { coarse } \\
\text { fragments; sludgey, aromatic, spongey }\end{array}$ \\
\hline 4 & $76-92$ & $\begin{array}{c}\text { Very dark grayish-brown }(2.5 \mathrm{Y} 3 / 2) \text { loam; structureless; loose; clear lower boundary; } \\
\text { abundant roots; < } 1 \% \text { coarse fragments; paucity of snail; } 1 \text { very well preserved fragment } \\
\text { of wood, generally organic rich; spongey texture and very wet after being exposed for } 2 \\
\text { days }\end{array}$ \\
\hline 5 & $45-76$ & $\begin{array}{c}\text { Black (7.5YR 2.5/1) clay loam; structureless; loose; clear lower boundary; contains well- } \\
\text { preserved wood fragments; } 5 \% \text { snail shell fragments, possible hydrobiidae; }<1 \% \text { coarse } \\
\text { fragments }\end{array}$ \\
\hline 6 & $26-45$ & Same as Zone 5; abrupt lower boundary \\
\hline 7 & $22-26$ & $\begin{array}{l}\text { Very dark grayish-brown (10YR 3/2) clay; structureless; loose; very abrupt lower } \\
\text { boundary; few distinct fine very pale brown (10YR 8/2) mottles; few distinct mottles of } \\
\text { Zone 8; common fine shell fragments; 3\% coarse fragments }\end{array}$ \\
\hline 8 & $0-22$ & $\begin{array}{c}\text { Olive brown ( } 2.5 \mathrm{Y} 4 / 4) \text { clay; moderate fine blocky structure; very friable; filamental } \\
\text { carbonates; few root pseudomorphs, gleyed with gray clay hypocoat; } 2 \% \text { coarse } \\
\text { fragments }\end{array}$ \\
\hline
\end{tabular}




\section{Appendix B}

\section{RADiOCARbon Results}

\begin{tabular}{|c|c|c|c|c|c|c|}
\hline $\begin{array}{c}\text { Site } \\
\text { Number }\end{array}$ & $\begin{array}{c}\text { Core } \\
\text { Number }\end{array}$ & Depth & Marker Strata & $\begin{array}{l}\text { Sample } \\
\text { Type }\end{array}$ & $\begin{array}{c}\text { Sample } \\
\text { ID (Beta-) }\end{array}$ & $\begin{array}{l}\text { Results (2-Sigma } \\
\text { Calibration) }\end{array}$ \\
\hline 1 & $\mathrm{n} / \mathrm{a}$ & $40-45^{*}$ & $\begin{array}{l}\text { Organic-rich deposit between } \\
\text { gravelly beds }\end{array}$ & Wood & 282624 & $\begin{array}{c}11370-11240 \text { cal BC } \\
(13320-13190 \text { cal BP })\end{array}$ \\
\hline 2 & 2 & $26-35$ & Top of fining-up sequence & $\begin{array}{l}\text { Organic } \\
\text { Sediment }\end{array}$ & 282620 & $\begin{array}{c}\text { cal AD } 440-490 \\
(1510-1460 \mathrm{cal} \mathrm{BP}) / \\
\text { cal AD } 520-640 \\
(1430-1310 \mathrm{cal} \mathrm{BP})\end{array}$ \\
\hline 3 & 3 & $0-8$ & $\begin{array}{l}\text { Sandy deposit beneath fining- } \\
\text { up sequence }\end{array}$ & $\begin{array}{l}\text { Organic } \\
\text { Sediment }\end{array}$ & 282621 & $\begin{array}{c}840-780 \text { cal BC } \\
(2790-2730 \text { cal BP })\end{array}$ \\
\hline 7 & 6 & $40-48$ & $\begin{array}{l}\text { Deposit with soil development } \\
\text { (structure, pedogenic } \\
\text { carbonate) and } 30 \% \text { coarse } \\
\text { fragments }\end{array}$ & $\begin{array}{l}\text { Organic } \\
\text { Sediment }\end{array}$ & 282622 & $\begin{array}{l}5730-5630 \text { cal BC } \\
(7680-7580 \text { cal BP) }\end{array}$ \\
\hline 7 & 6 & $20-27$ & $\begin{array}{l}\text { Deposit with most prominent } \\
\text { soil development (structure, } \\
\text { pedogenic carbonate) and } \\
<15 \% \text { coarse fragments }\end{array}$ & $\begin{array}{l}\text { Organic } \\
\text { Sediment }\end{array}$ & 282623 & $\begin{array}{c}17350-17070 \text { cal BC } \\
(19300-19020 \text { cal BP })\end{array}$ \\
\hline 9 & 10 & $22-26$ & $\begin{array}{l}\text { Yellowish brown clay beneath } \\
\text { unconformity }\end{array}$ & $\begin{array}{l}\text { Organic } \\
\text { Sediment }\end{array}$ & 287890 & $\begin{array}{c}8550-8280 \mathrm{cal} \mathrm{BC} \\
(10500-10240 \mathrm{cal} \mathrm{BP})\end{array}$ \\
\hline 10 & 11 & $20-24$ & $\begin{array}{l}\text { Black clay loam above } \\
\text { unconformity }\end{array}$ & $\begin{array}{l}\text { Organic } \\
\text { Sediment }\end{array}$ & 287891 & $\begin{array}{c}\text { cal AD } 720-740 \\
(1230-1210 \mathrm{cal} \mathrm{BP}) / \\
\text { cal AD } 770-970 \\
(1180-980 \mathrm{cal} \mathrm{BP})\end{array}$ \\
\hline 11 & 12 & $14-18$ & $\begin{array}{l}\text { Very dark gray clay loam } \\
\text { above unconformity }\end{array}$ & $\begin{array}{l}\text { Organic } \\
\text { Sediment }\end{array}$ & 287892 & $\begin{array}{c}6460-6340 \mathrm{cal} \mathrm{BC} \\
(8410-8290 \mathrm{cal} \mathrm{BP}) / \\
6310-6260 \mathrm{cal} \mathrm{BC} \\
(8260-8210 \mathrm{cal} \mathrm{BP})\end{array}$ \\
\hline 11 & 12 & $8-12$ & $\begin{array}{l}\text { Olive brown clay beneath } \\
\text { unconformity }\end{array}$ & $\begin{array}{l}\text { Organic } \\
\text { Sediment }\end{array}$ & 287893 & $\begin{array}{l}\text { cal AD 650-780 } \\
(1300-1170 \text { cal BP) }\end{array}$ \\
\hline
\end{tabular}

Note: Depths are recorded in centimeters $(\mathrm{cm})$ above bottom of cores.

*Depth of this core is recorded in centinmeters below the lake bed. 


\section{Appendix C}

\section{RAdiocarbon Results}

\begin{tabular}{|c|c|c|c|c|c|c|}
\hline $\begin{array}{c}\text { Site } \\
\text { Number }\end{array}$ & $\begin{array}{c}\text { Core } \\
\text { Number }\end{array}$ & Depth & Marker Strata & $\begin{array}{l}\text { Sample } \\
\text { Type }\end{array}$ & $\begin{array}{c}\text { Sample } \\
\text { ID (Beta-) }\end{array}$ & $\begin{array}{l}\text { Results (2-Sigma } \\
\text { Calibration) }\end{array}$ \\
\hline 1 & $\mathrm{n} / \mathrm{a}$ & $40-45^{*}$ & $\begin{array}{l}\text { Organic-rich deposit between } \\
\text { gravelly beds }\end{array}$ & Wood & 282624 & $\begin{array}{c}11370-11240 \text { cal BC } \\
(13320-13190 \text { cal BP })\end{array}$ \\
\hline 2 & 2 & $26-35$ & Top of fining-up sequence & $\begin{array}{l}\text { Organic } \\
\text { Sediment }\end{array}$ & 282620 & $\begin{array}{l}\text { cal AD } 440-490 \\
(1510-1460 \text { cal BP }) / \\
\text { cal AD 520-640 } \\
(1430-1310 \text { cal BP })\end{array}$ \\
\hline 3 & 3 & $0-8$ & $\begin{array}{l}\text { Sandy deposit beneath fining- } \\
\text { up sequence }\end{array}$ & $\begin{array}{l}\text { Organic } \\
\text { Sediment }\end{array}$ & 282621 & $\begin{array}{c}840-780 \text { cal BC } \\
(2790-2730 \text { cal BP })\end{array}$ \\
\hline 7 & 6 & $40-48$ & $\begin{array}{c}\text { Deposit with soil development } \\
\text { (structure, pedogenic } \\
\text { carbonate) and } 30 \% \text { coarse } \\
\text { fragments }\end{array}$ & $\begin{array}{l}\text { Organic } \\
\text { Sediment }\end{array}$ & 282622 & $\begin{array}{l}5730-5630 \mathrm{cal} \mathrm{BC} \\
(7680-7580 \mathrm{cal} \mathrm{BP})\end{array}$ \\
\hline 7 & 6 & $20-27$ & $\begin{array}{l}\text { Deposit with most prominent } \\
\text { soil development (structure, } \\
\text { pedogenic carbonate) and } \\
<15 \% \text { coarse fragments }\end{array}$ & $\begin{array}{l}\text { Organic } \\
\text { Sediment }\end{array}$ & 282623 & $\begin{array}{c}17350-17070 \mathrm{cal} \mathrm{BC} \\
(19300-19020 \mathrm{cal} \mathrm{BP})\end{array}$ \\
\hline 9 & 10 & $22-26$ & $\begin{array}{l}\text { Yellowish brown clay beneath } \\
\text { unconformity }\end{array}$ & $\begin{array}{l}\text { Organic } \\
\text { Sediment }\end{array}$ & 287890 & $\begin{array}{c}8550-8280 \mathrm{cal} \mathrm{BC} \\
(10500-10240 \mathrm{cal} \mathrm{BP})\end{array}$ \\
\hline 10 & 11 & $20-24$ & $\begin{array}{c}\text { Black clay loam above } \\
\text { unconformity }\end{array}$ & $\begin{array}{l}\text { Organic } \\
\text { Sediment }\end{array}$ & 287891 & $\begin{array}{c}\text { cal AD } 720-740 \\
(1230-1210 \text { cal BP }) / \\
\text { cal AD } 770-970 \\
(1180-980 \text { cal BP })\end{array}$ \\
\hline 11 & 12 & $14-18$ & $\begin{array}{l}\text { Very dark gray clay loam } \\
\text { above unconformity }\end{array}$ & $\begin{array}{l}\text { Organic } \\
\text { Sediment }\end{array}$ & 287892 & $\begin{array}{c}6460-6340 \text { cal BC } \\
(8410-8290 \mathrm{cal} \mathrm{BP}) / \\
6310-6260 \mathrm{cal} \mathrm{BC} \\
(8260-8210 \text { cal BP })\end{array}$ \\
\hline 11 & 12 & $8-12$ & $\begin{array}{l}\text { Olive brown clay beneath } \\
\text { unconformity }\end{array}$ & $\begin{array}{l}\text { Organic } \\
\text { Sediment }\end{array}$ & 287893 & $\begin{array}{l}\text { cal AD 650-780 } \\
(1300-1170 \text { cal BP })\end{array}$ \\
\hline
\end{tabular}

Note: Depths are recorded in centimeters $(\mathrm{cm})$ above bottom of cores.

*Depth of this core is recorded in centinmeters below the lake bed. 


\section{Appendix D}

\section{Test Location Maps}

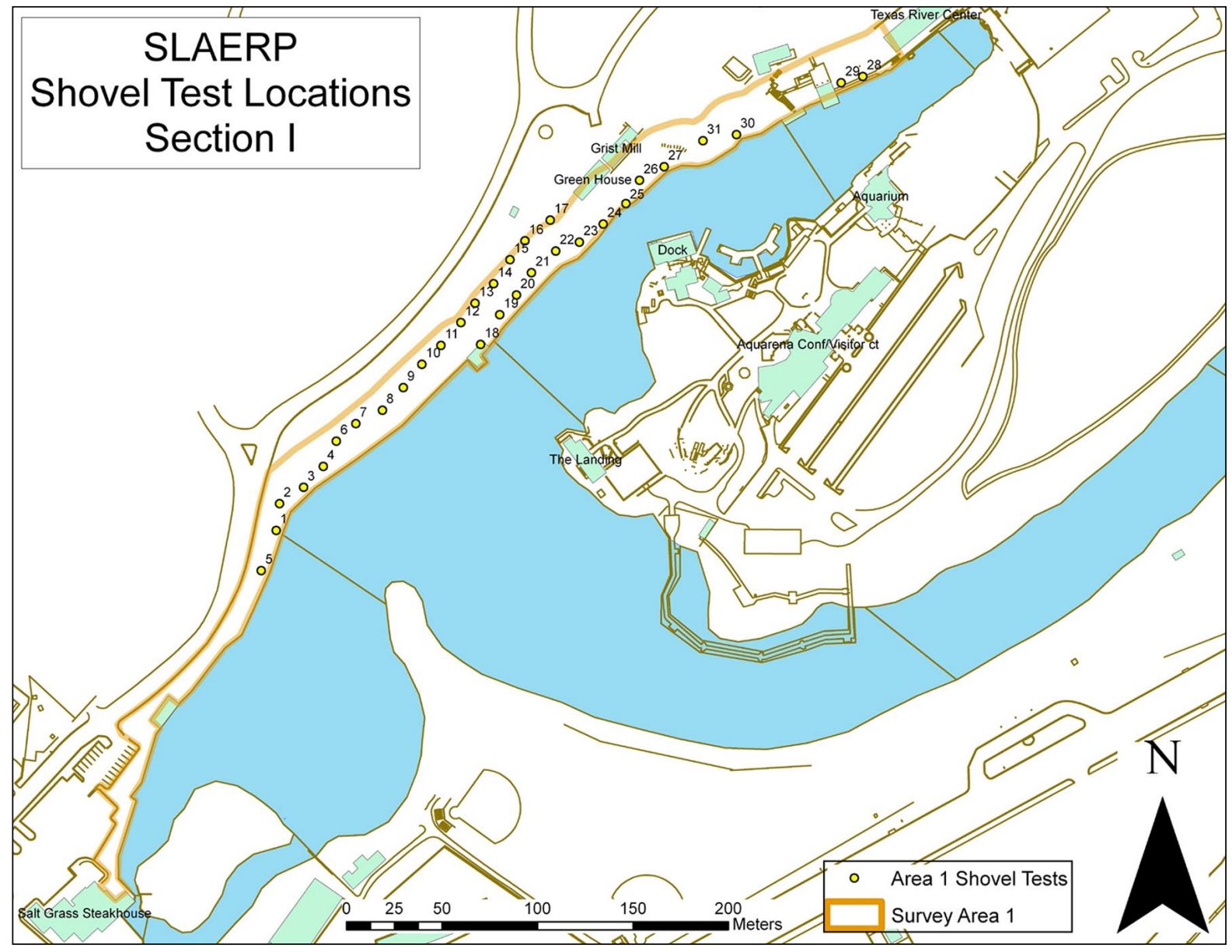

Figure D-1. Section I shovel test locations. 


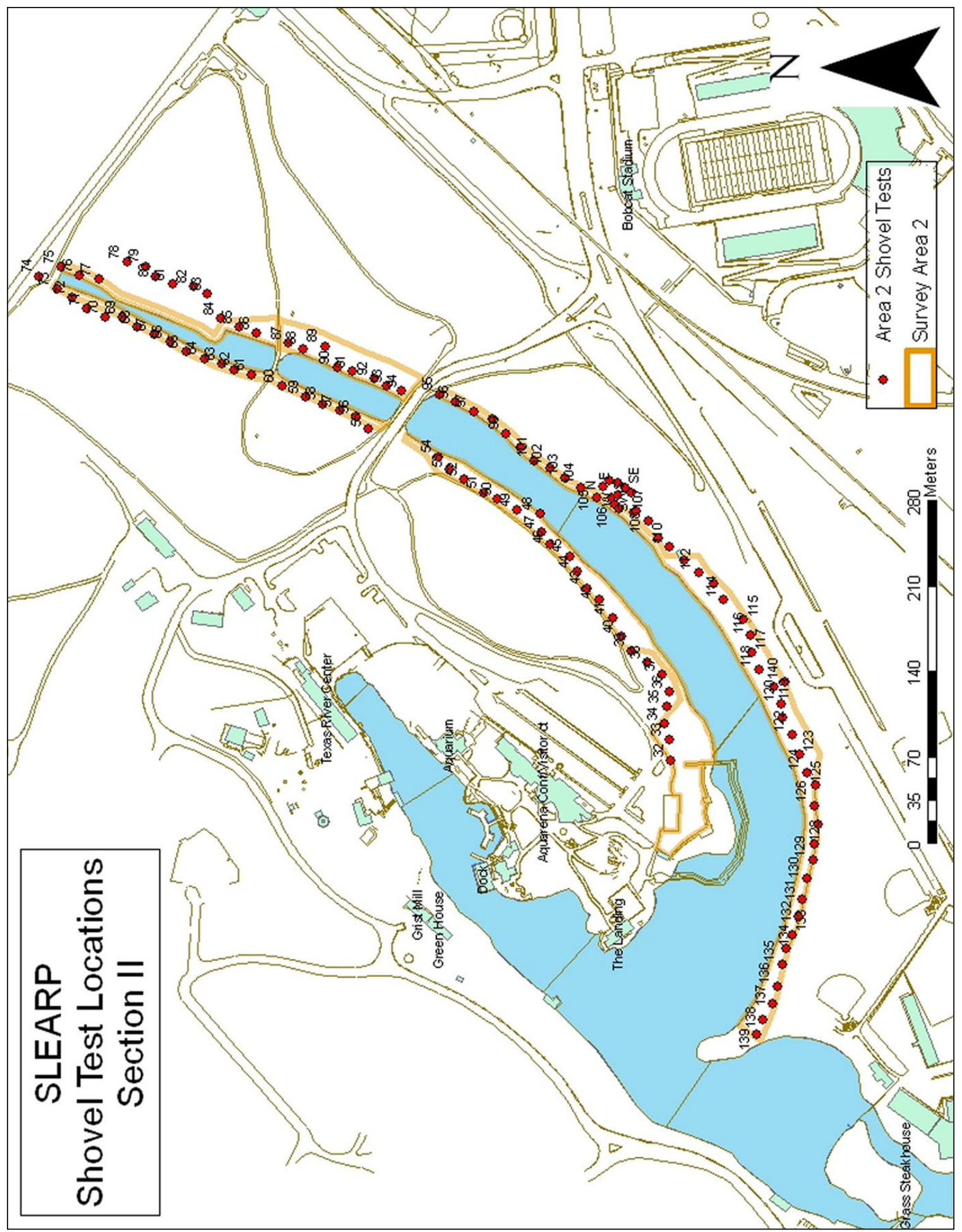

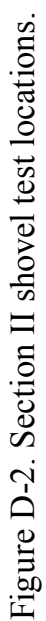




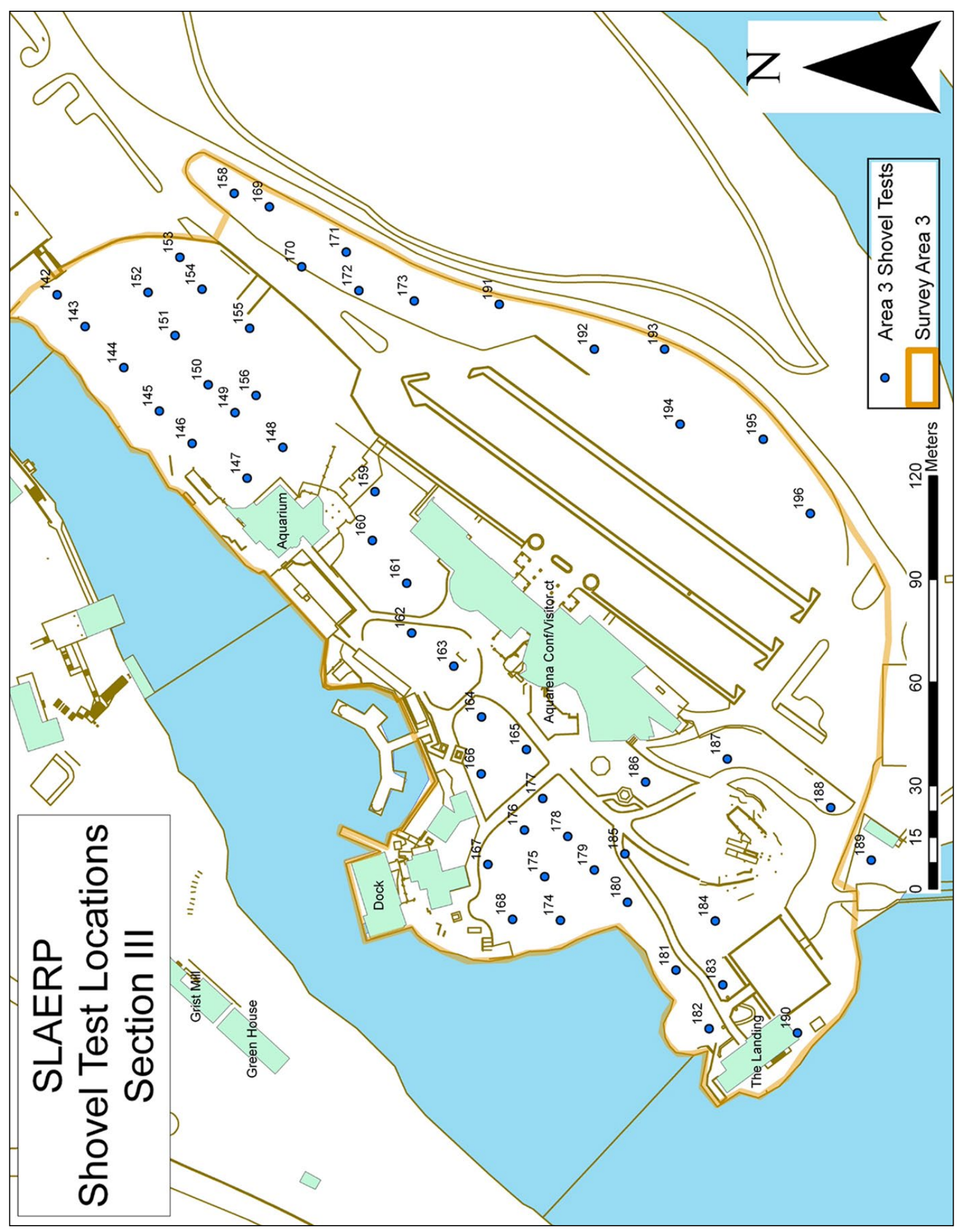

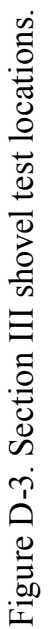




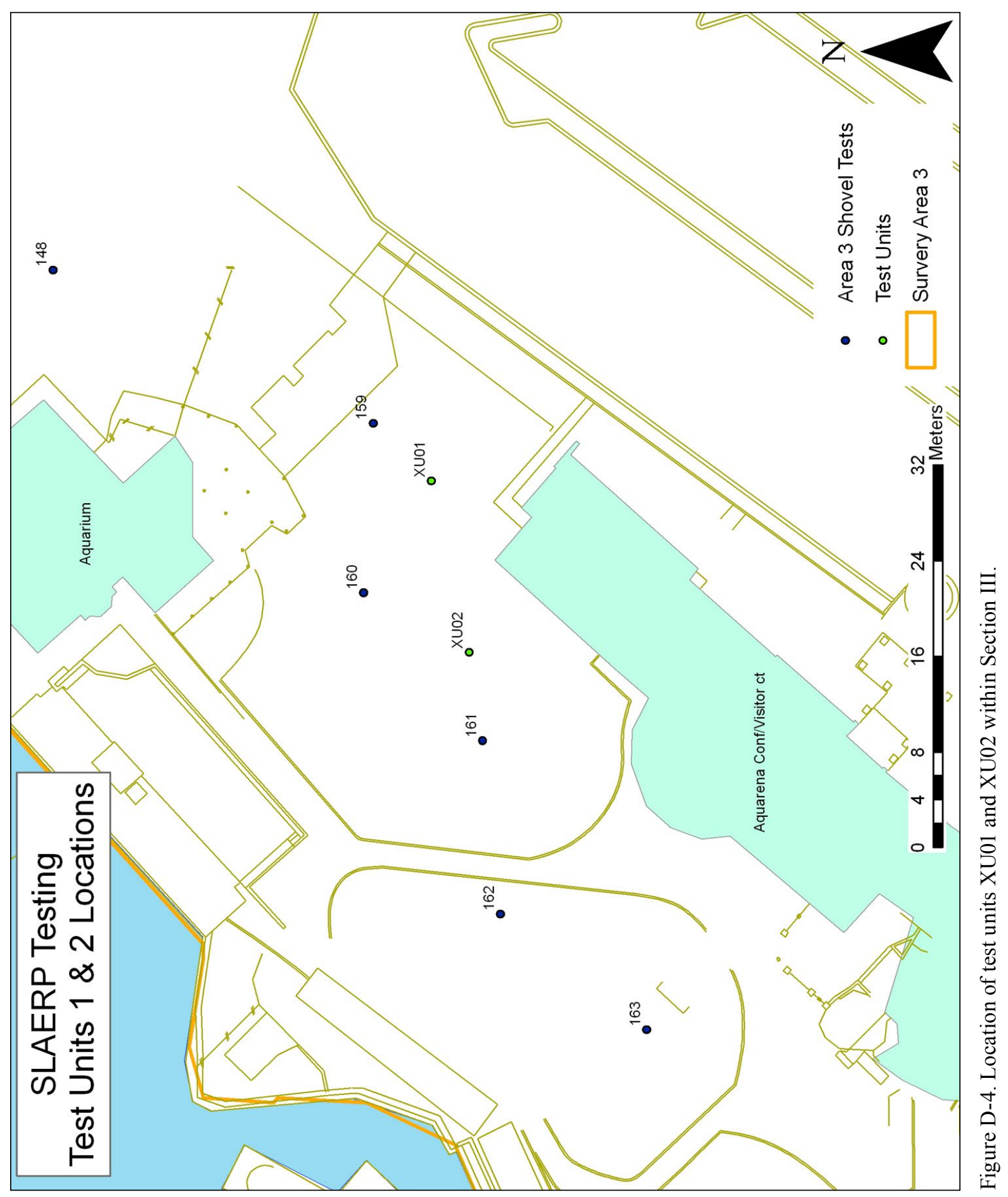


FIGURE D-5. REDACTED

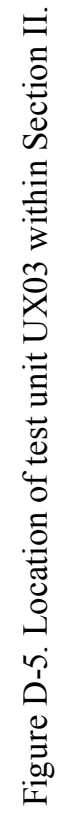




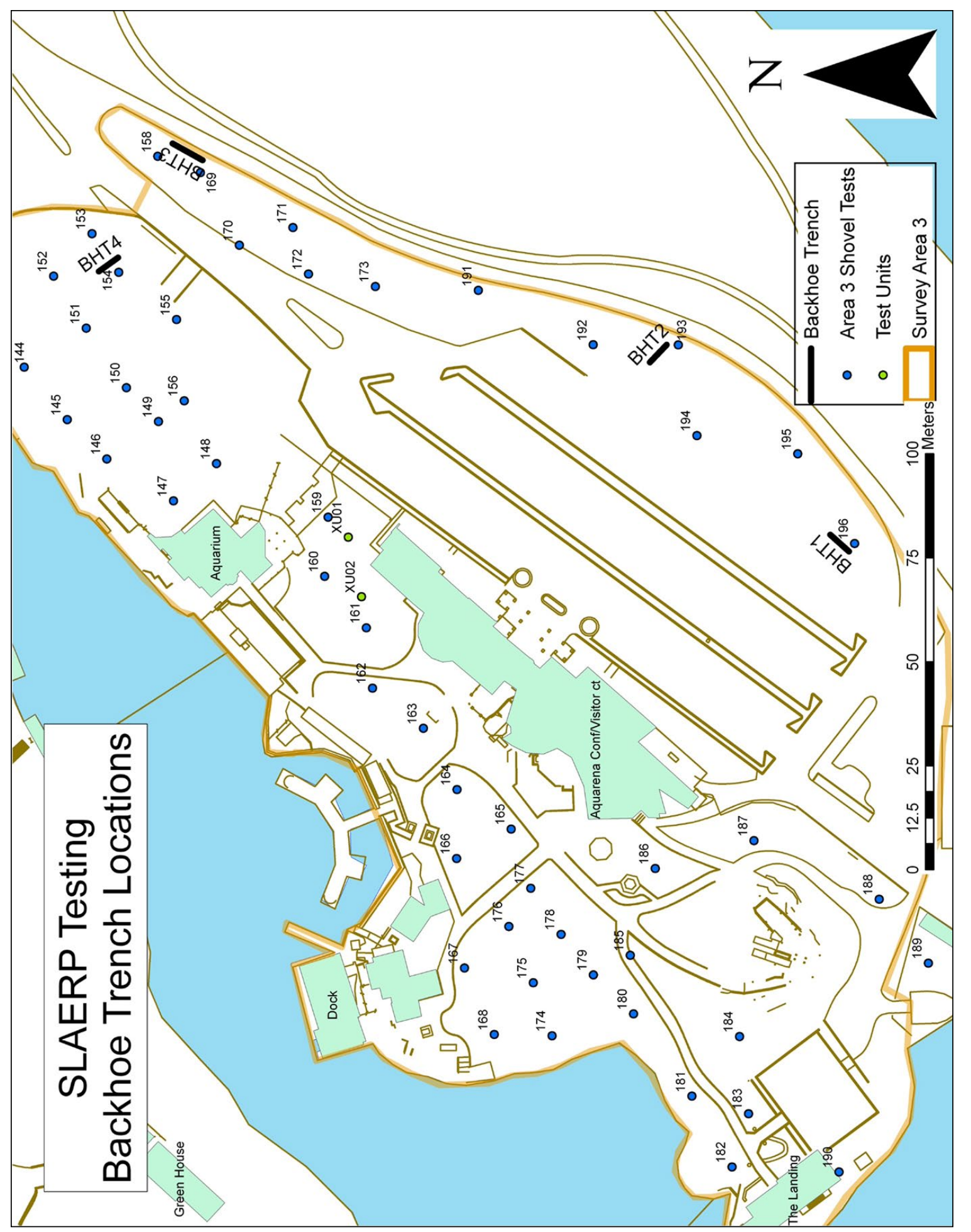

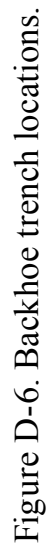




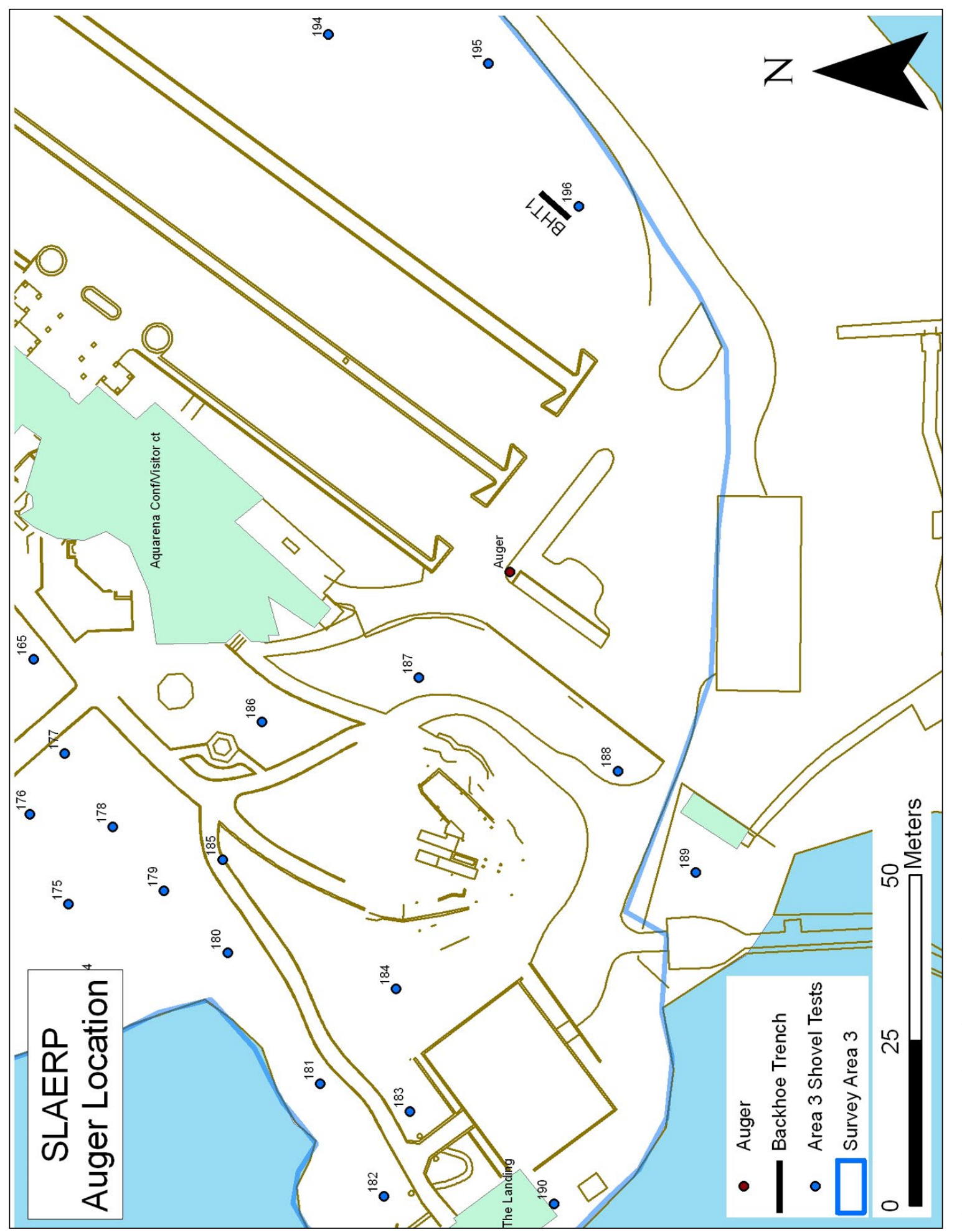

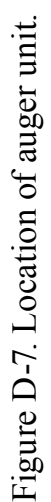




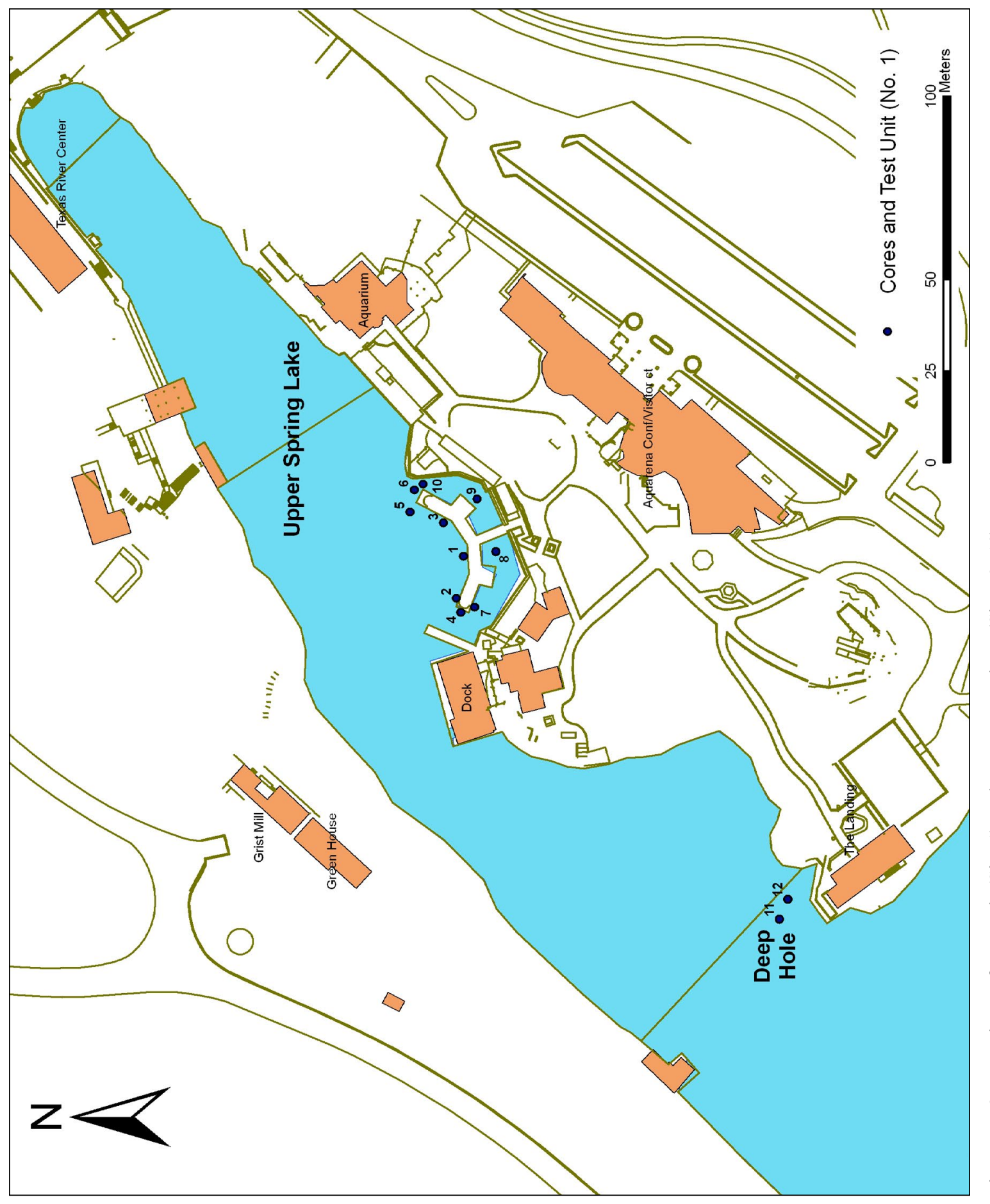

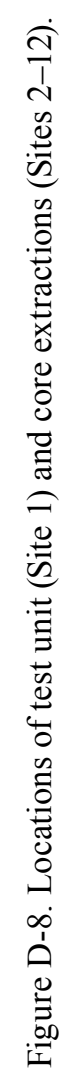




\section{Appendix E}

\section{Site MAPS}

FIGURE E-1 REDACTED

Figure E-1. Previously recorded archaeological sites in and near the project area. Site boundaries have never been precisely mapped for any of these sites, and deposits may extend beyond areas indicated. 
FIGURE E-2. REDACTED

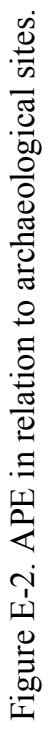




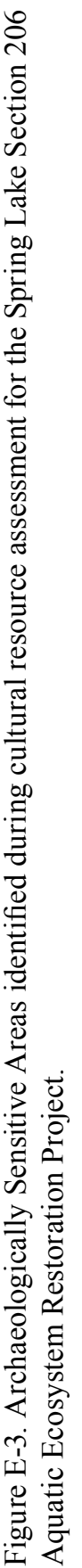


FIGURE E-4. REDACTED

Figure E-4. Archaeological sites within the project area. Dashed line boundaries are recently updated based on survey investigations. 
FIGURE E-5. REDACTED

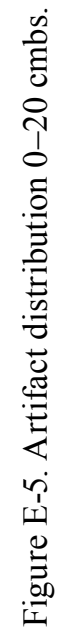


FIGURE E-6. REDACTED

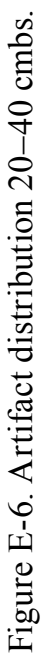


FIGURE E-7. REDACTED

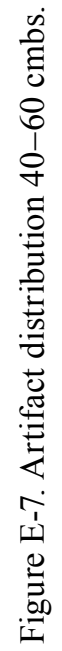


FIGURE E-8. REDACTED

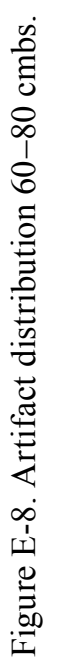


FIGURE E-9. REDACTED 
FIGURE E-10. REDACTED

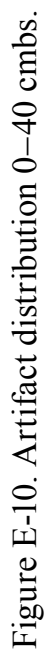


FIGURE E-11. REDACTED

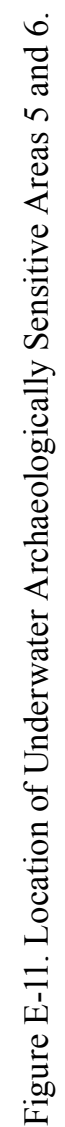


